INTERNATIONAL MONETARY FUND

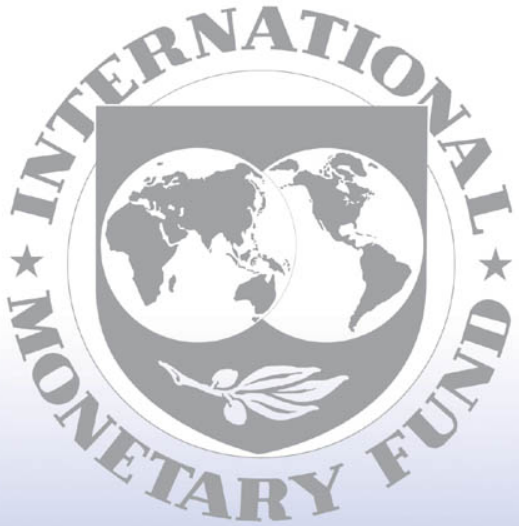

Staff

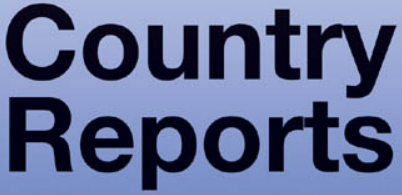




\section{Turkey: Second Review Under the Stand-By Arrangement-Staff Report; Staff Statement; News Brief on the Executive Board Discussion; and Statement by the Authorities of Turkey}

In the context of the Sccond Review Under the Stand-By Arrangement, the following documents have been released and are included in this package:

- the staff report for the second review under the Stand-By Arrangement prcpared by a staff team of the IMF, following discussions that ended on May 27, 2002, with the officials of Turkey on economic developments and policies. Based on information available at the time of these discussions, the staff report was completed on June 20, 2002. The views expressed in the staff report are those of the staff team and do not necessarily reflect the views of the Executive Board of the IMF.

- a staff statement of June 28, 2002 updating information on recent developments.

- a News Brief summarizing the views of the Executive Board as expressed during its June 28, 2002 discussion of the staff report that completed the review.

- a statement by the Authorities of Turkey.

The documents listed below have been or will be separately released.

Letter of Intent sent to the IMF by the authorities of Turkey*

* May also be included in Staff Report

The policy of publication of staff reports and other documents allows for the deletion of market-sensitive information.

To assist the IMF in evaluating the publication policy, reader comments are invited and may be sent by e-mail to Publicationpolicy@imf.org.

Copies of this report are available to the public from

International Monetary Fund - Publication Services

$70019^{\text {th }}$ Street, N.W. - Washington, D.C. 20431

Telephone: (202) 623-7430 - Telefax: (202) 623-7201

E-mail: publications@imf.org Intemet: http://www.imf.org

Price: $\$ 15.00$ a copy

\section{International Monetary Fund \\ Washington, D.C.}


INTERNATIONAL MONETARY FUND

TURKEY

Second Review Under the Stand-by Arrangement

Prepared by European I Department in Consultation with Other Departments

Approved by Susan Schadler and Liam P. Ebrill

June 20,2002

- Discussions for the second review under the Stand-by Arrangement with Turkey were held in Ankara and Istanbul during May 15-27, 2002.

The staff participating in the mission comprised Messrs. Kähkönen (head), Aitken, Griffiths, and Rossi (all EU1), Messrs. Hemming and Flanagan (FAD), Mr. Laryea (LEG), Messrs. Marston and Josefsson, and Ms. Gutierrez (all MAE), and Mr. McGettigan (PDR). Mr. Brekk, senior resident representative, and Mr. Piñerúa, MAE representative, assisted the mission, and the mission cooperated closely with World Bank staff on structural issues. Mr. Cakir, Advisor to the Executive Director for Turkey, attended several meetings.

The mission met with the State Minister for Economic Affairs, Mr. Derviş; the State Minister for Foreign Trade, Mr. Toskay; the State Minister for Labor Relations, Mr. Keçeciler; the Minjster of Finance, Mr. Oral; the Minister for Privatization, Mr. Karaköyunlu; the Minister for Justice, Mr. Türk; the Minister for Transportation, Mr. Vural; the Undersecretary of the Treasury, Mr. Öztrak; the Undersecretary of the State Planning Organization, Mr. Izmirlioglu; the Undersecretary of Finance, Mr. Dikmen; the Governor of the Central Bank of Turkey, Mr. Serdengeçti; the Chairman of the Bank Regulation and Supervision Agency, Mr. Akçakoca; and other senior officials; as well as representatives of the private banking and business communities.

- Under the Stand-by Arrangement approved on February 4, 2002, the Central Bank of Turkey was subject to a full safeguards assessment. This was completed on April 4, 2002. In the first program review completed on April 15, 2002, some of the actions identified in the safeguards assessment were included under Fund conditionality. None of this conditionality applies to this review.

- The Turkish authorities intend to allow the publication of the staff report. 


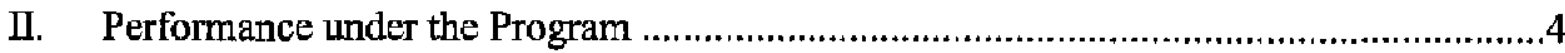

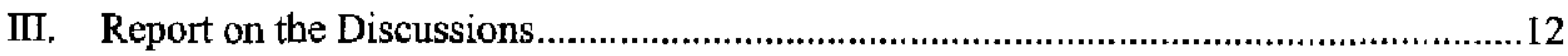

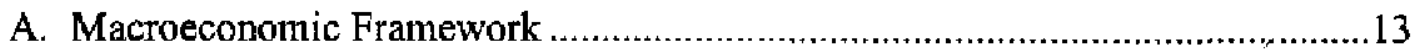

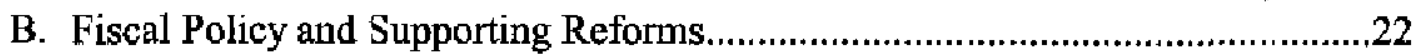

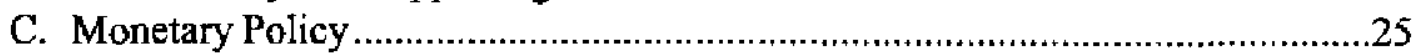

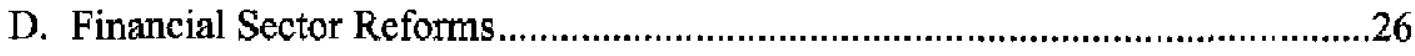

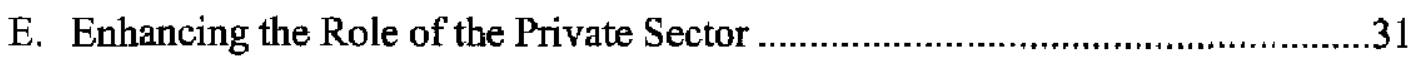

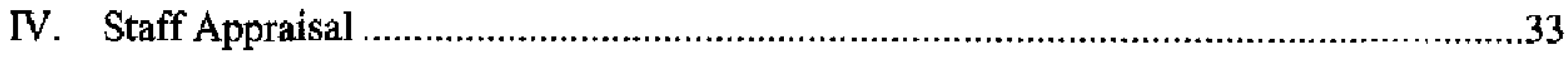

$\underline{\text { Text Boxes }}$

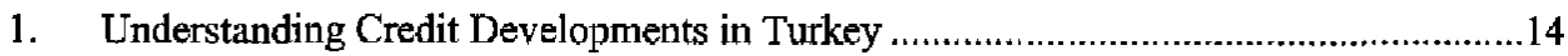

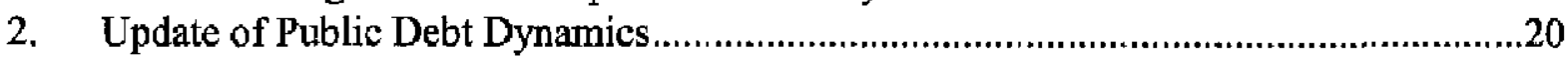

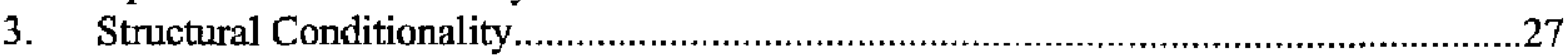

4. Capital Adequacy of Turkish Private Banks ........................................................28

5. What is the Istanbul Approach? ........................................................................30

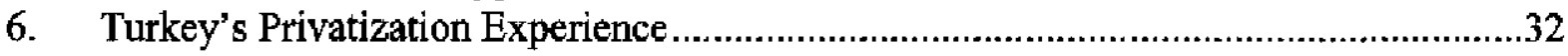

\section{$\underline{\text { Figures }}$}

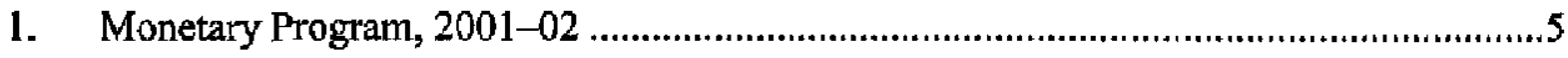

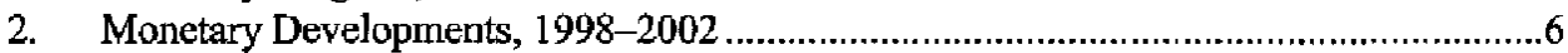

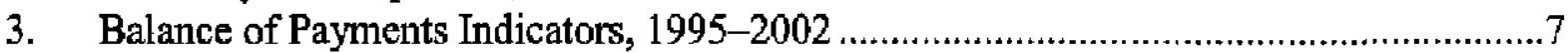

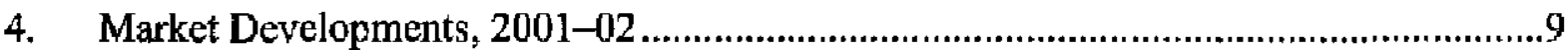

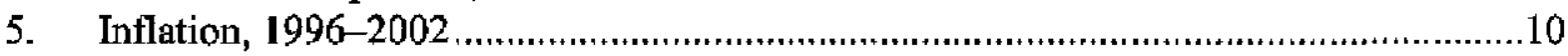

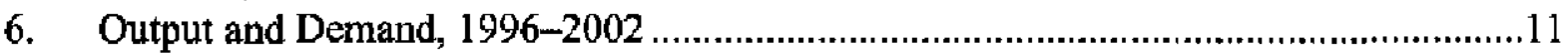

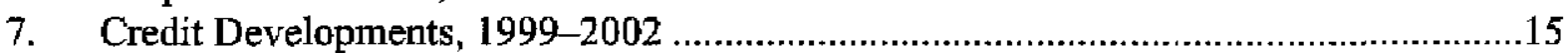

8. $\quad$ Real GDP and Real Credit, 1987-2001 …............................................................16

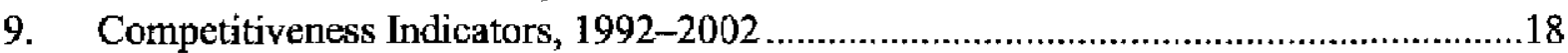

10. CBT Tendency Survey Findings: Export Prospects for the Second Quarter of $2002 \ldots . .19$

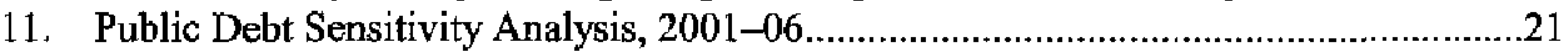

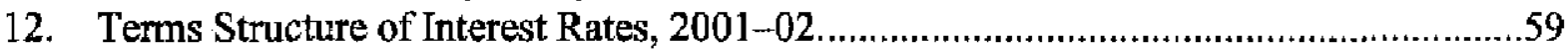

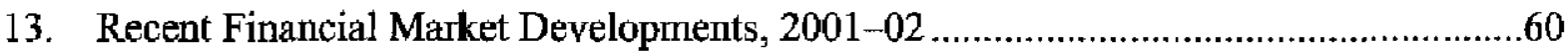


Tables

1. Prior Actions and Benchmarks Relevant for the Second Review ...............................36

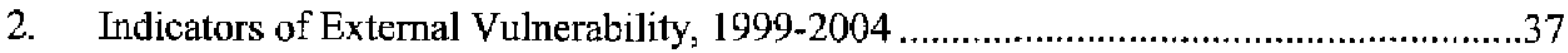

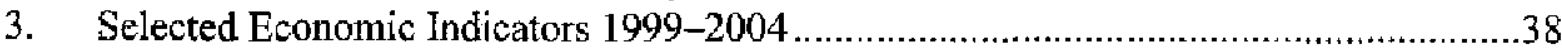

4. $\quad$ Balance of Payments, 1998-2005 .....................................................................

5. Composition of Public Sector Net Debt............................................................ 41

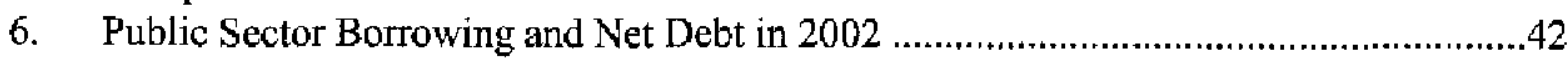

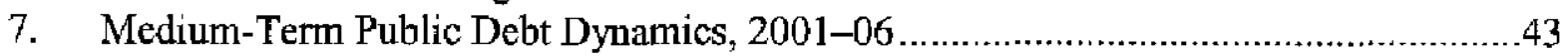

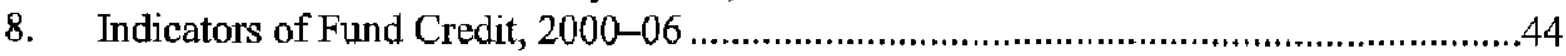

9. External Financing Requirements and Sources, 1998-2006 …...............................45

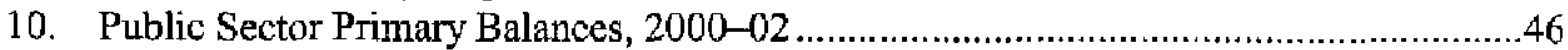

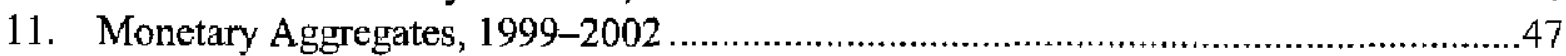

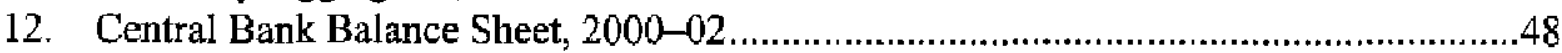

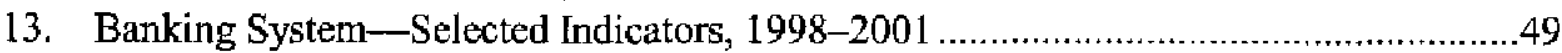

14. Public Sector Financing Indicators, 2001-02 …..............................................61

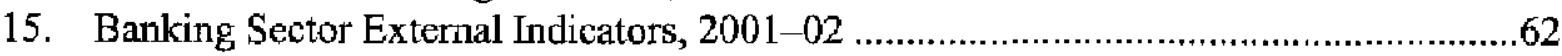

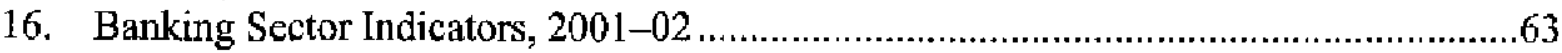

Appendices

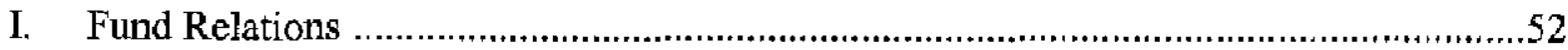

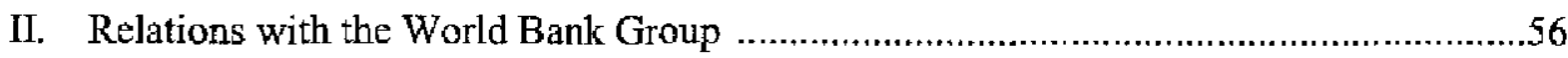

III Recent Developments in External and Financial Vulnerability .............................58

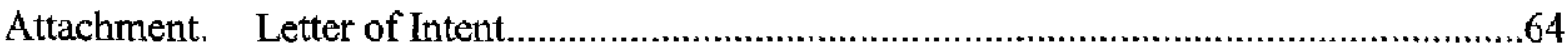

Annexes

A. Quantitative Performance Criteria and Indicative Targets for 2002 ...........................71

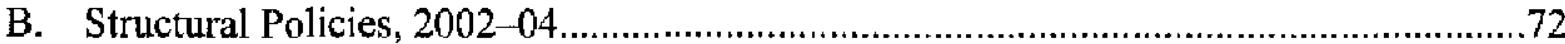

C. Indicative Target on Cumulative Privatization Proceeds of the Consolidated

Government Sector... 


\section{INTRODUCTION}

1. In the attached letter, the authorities review developments and policies under the program, and request the completion of the second review under the Stand-by Arrangement (SBA). The Fund is supporting Turkey's economic program under an SBA covering 2002-04, approved by the Executive Board on February 4, 2002. Total access under the arrangement is SDR 12.8 billion, or 1,330 percent of quota, of which SDR 8.2 billion has been purchased so far (Appendix I). The next purchase, in an amount equivalent to SDR 867.6 million, is contingent on the completion of this review. The World Bank supports Turkey under a Country Assistance Strategy envisaging lending of up to US\$6.2 billion during FY2001-03 (Appendix II).

\section{Performance under the Program}

2. Since the completion of the Article IV consultation and the first review in April 2002, macroeconomic policies have remained in line with the program. All quantitative performance criteria for end-March and end-April have been met (Annex A of the attached Letter of Intent). The Central Bank of Turkey (CBT) has kept monetary aggregates well within program limits, and has secured a higher-than-programmed reserve position (Figures 1-3). Fiscal outturns also remain on track, although overperformance has diminished since early this year. The end-March performance criterion on the consolidated government sector primary surplus was met by a relatively small margin, as overperformance by the central government of 0.4 percent of annual GNP was almost completely offset by a much smaller than expected primary surplus in state economic enterprises (SEEs) due to higher energy costs and delays in raising prices. The end-May performance criterion is also expected to have been met: the non-SEE consolidated government sector (for which provisional data are available) has produced a primary surplus slightly exceeding that targeted for the whole sector, and indications are that SEEs (for which full data will be available in mid-July) will show a small primary surplus in April-May.

\section{The program's extensive structural conditionality for this review has been}

largely met (Table 1). All three end-April benchmarks (on preparing an external audit of the Savings Deposit and Insurance Fund (SDIF), passing indirect tax legislation, and establishing a steering group and subcommittee for public sector reform) were observed, albeit with some delay. The end-May benchmark on submitting a draft Foreign Direct Investment Law to parliament was also observed, with a two-week delay. As regards prior actions, in mid-June parliament passed the required amendments to the Public Procurement Law, and the Bank Regulation and Supervision Agency (BRSA) sent letters to banks after having completed its capital adequacy evaluations. Finally, although the privatization plan for Türk Telekom has not yet been adopted, substantial progress has been made toward meeting this prior action. The board of the company has approved a World-Bank endorsed corporatization plan, which envisages splitting the company into subsidiaries under a bolding company. As this plan requires a more complex privatization strategy than originally envisaged, including amendments to the Telecommunications Law, adoption of the privatization plan will not be 
Figure 1. Turkey: Monetary Program, 2001-02
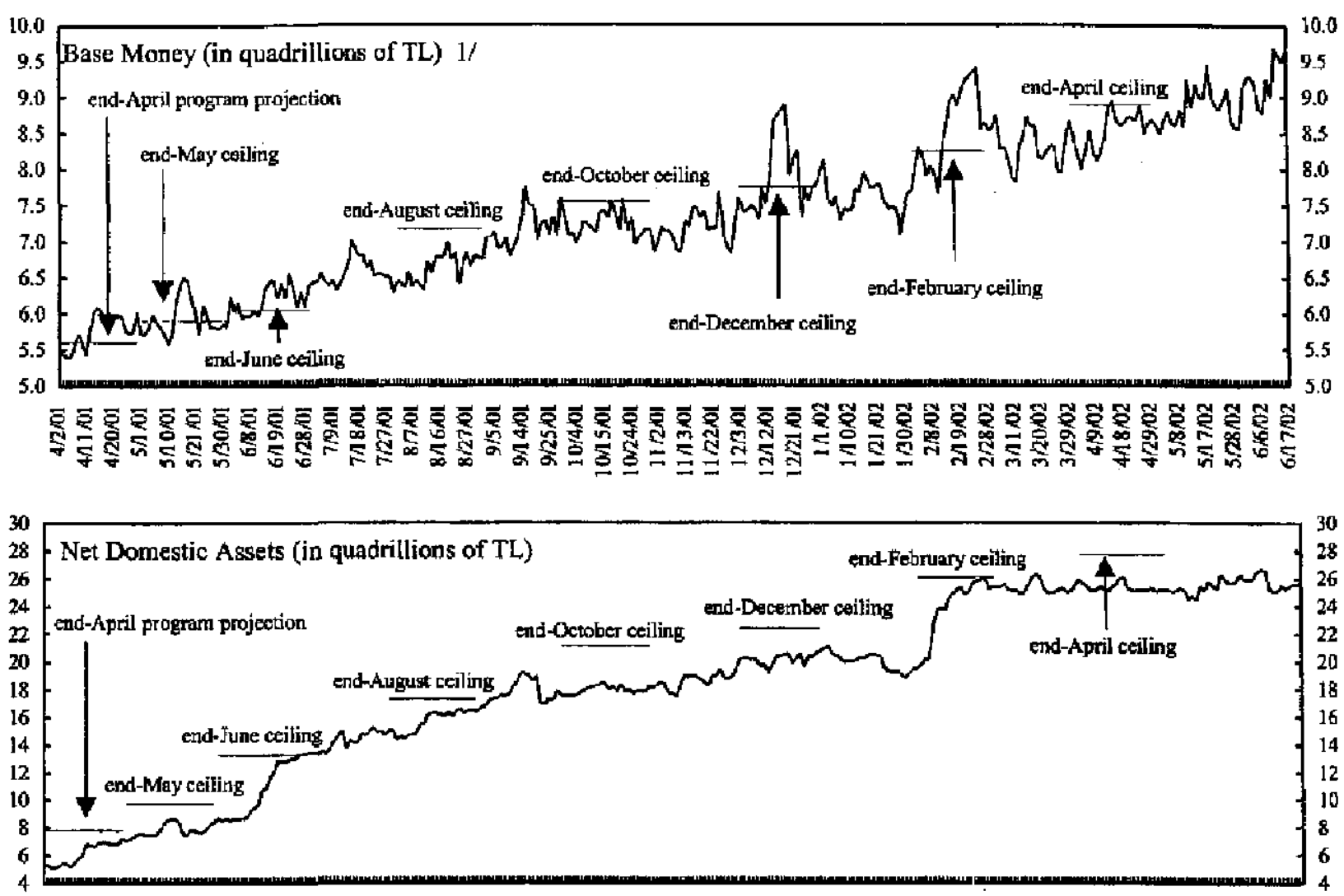

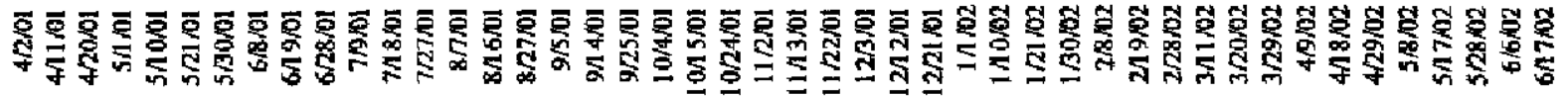

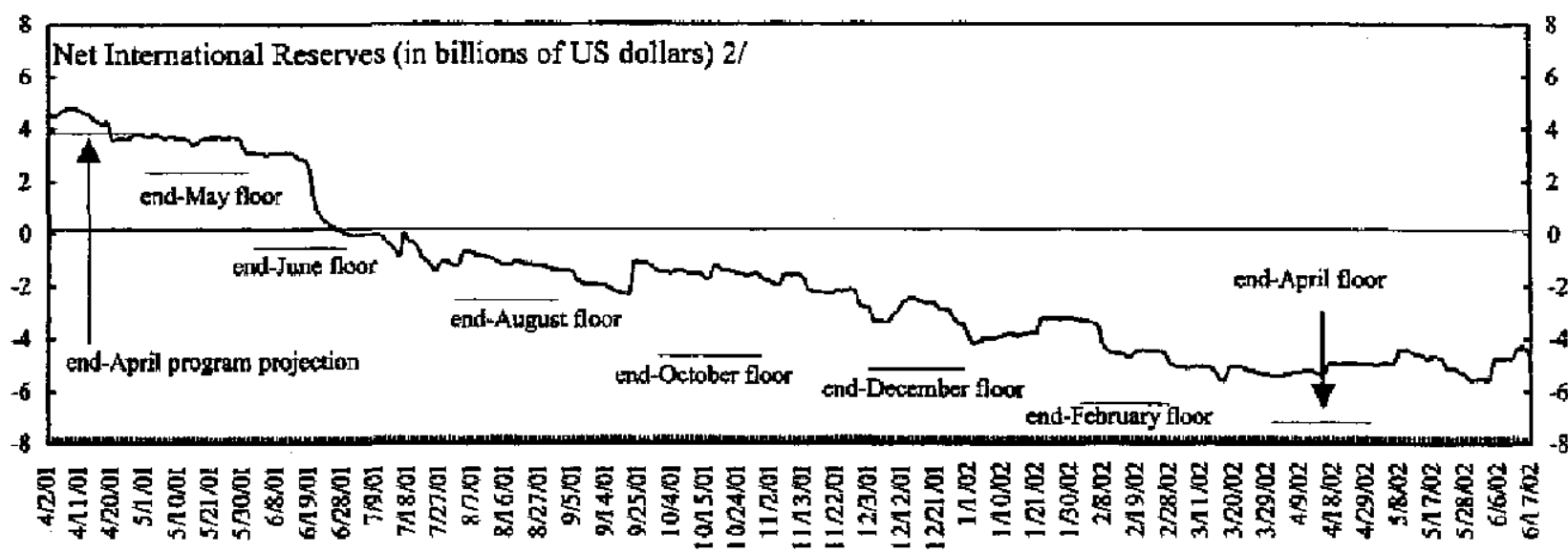

Source: Data from the Turkish authorities.

I/ As explained in Annex J of the Janury 18, 2002 Letter of Intent, the end-February test date was calculated as the four-day average of February 11-12 and March 11-12, to correct for the temporary increase in demand for base money due to the Bayram holiday. All monetary performance criteria and indicative ceilings were met.

2/ Data discontinuity at February 6, 2002 reflects the revised definition of NIR in the new program, which now includes the Treasury's NIR position, and which is calculated at new program cross exchange rates. 
Figure 2. Turkey: Monetary Developments, 1998-2002

Currency Composition of Bank Deposits, August 2000-Mry 2002

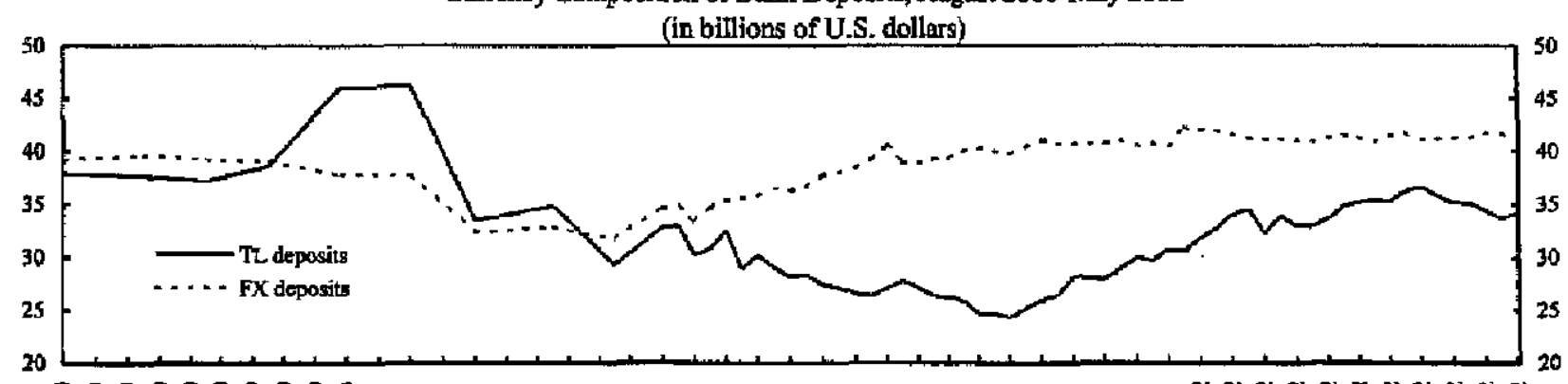

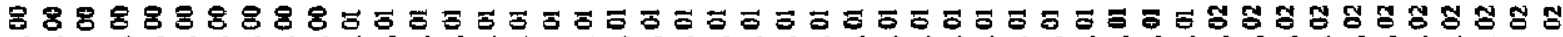

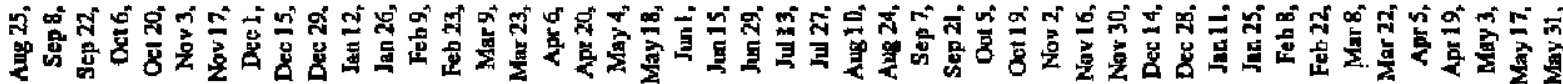

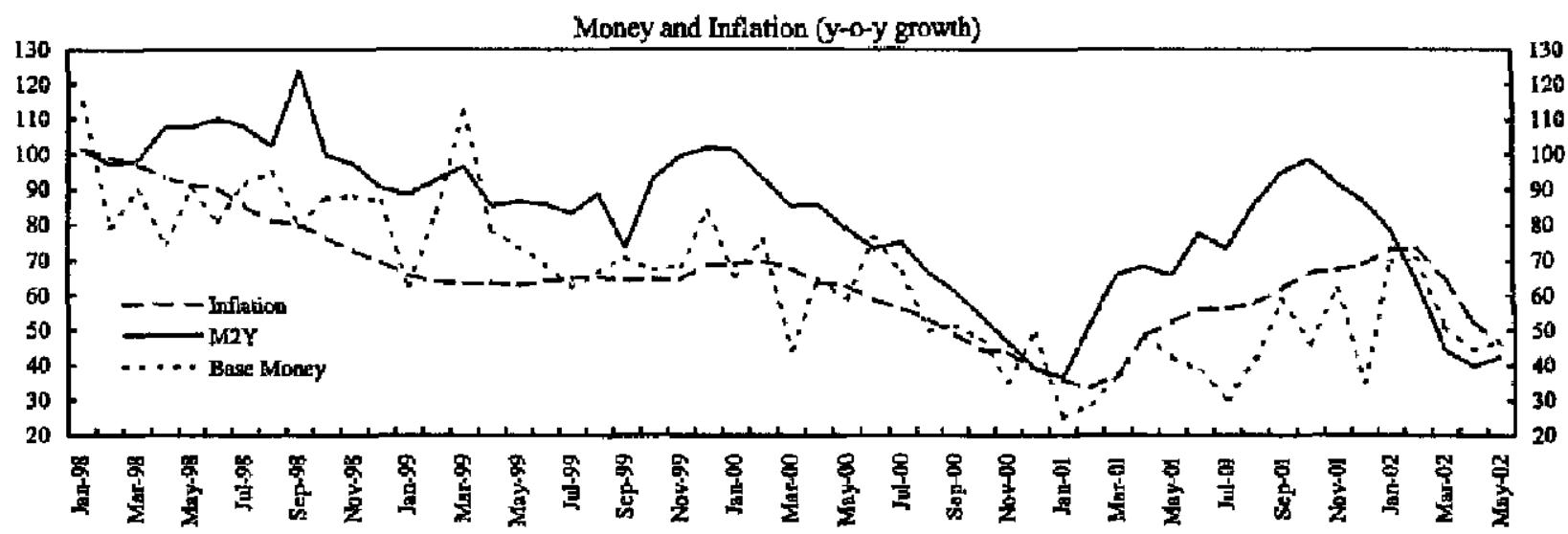

Real Bank Credit to the Private Sector

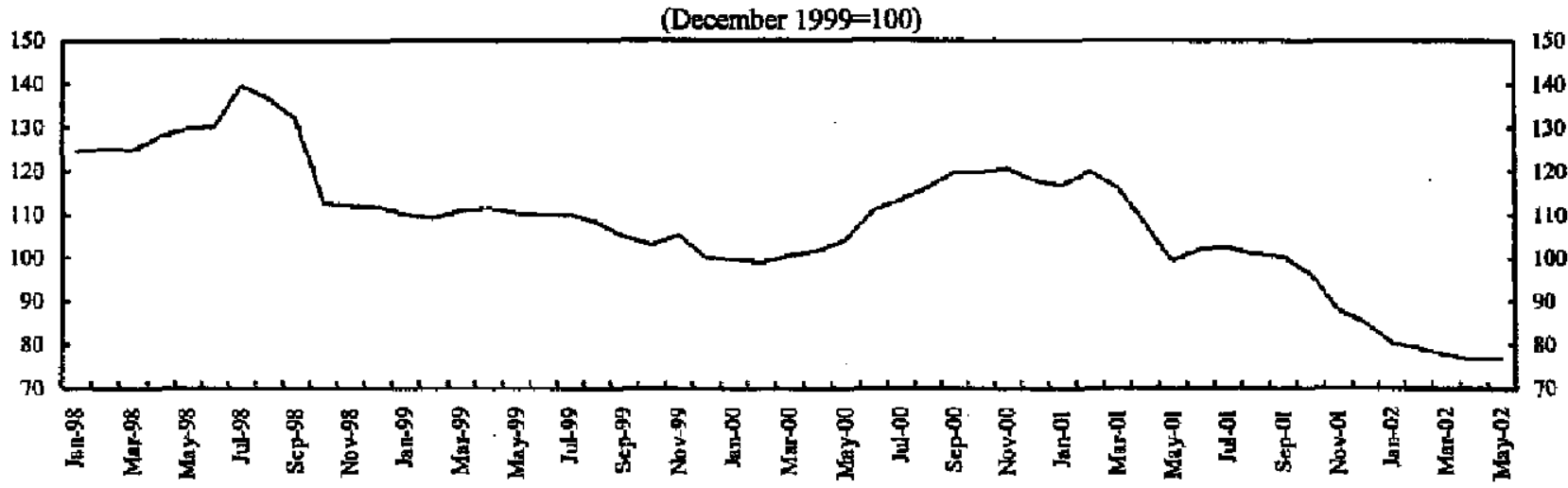

Sources: Central Bank of Turkey; and State Institute of Statistics.

1/ Turkish residents' TL deposits. 
Figure 3. Turkey: Balance of Payments Indicators, 1995-2002 (in bitlions of U.S. dollars)
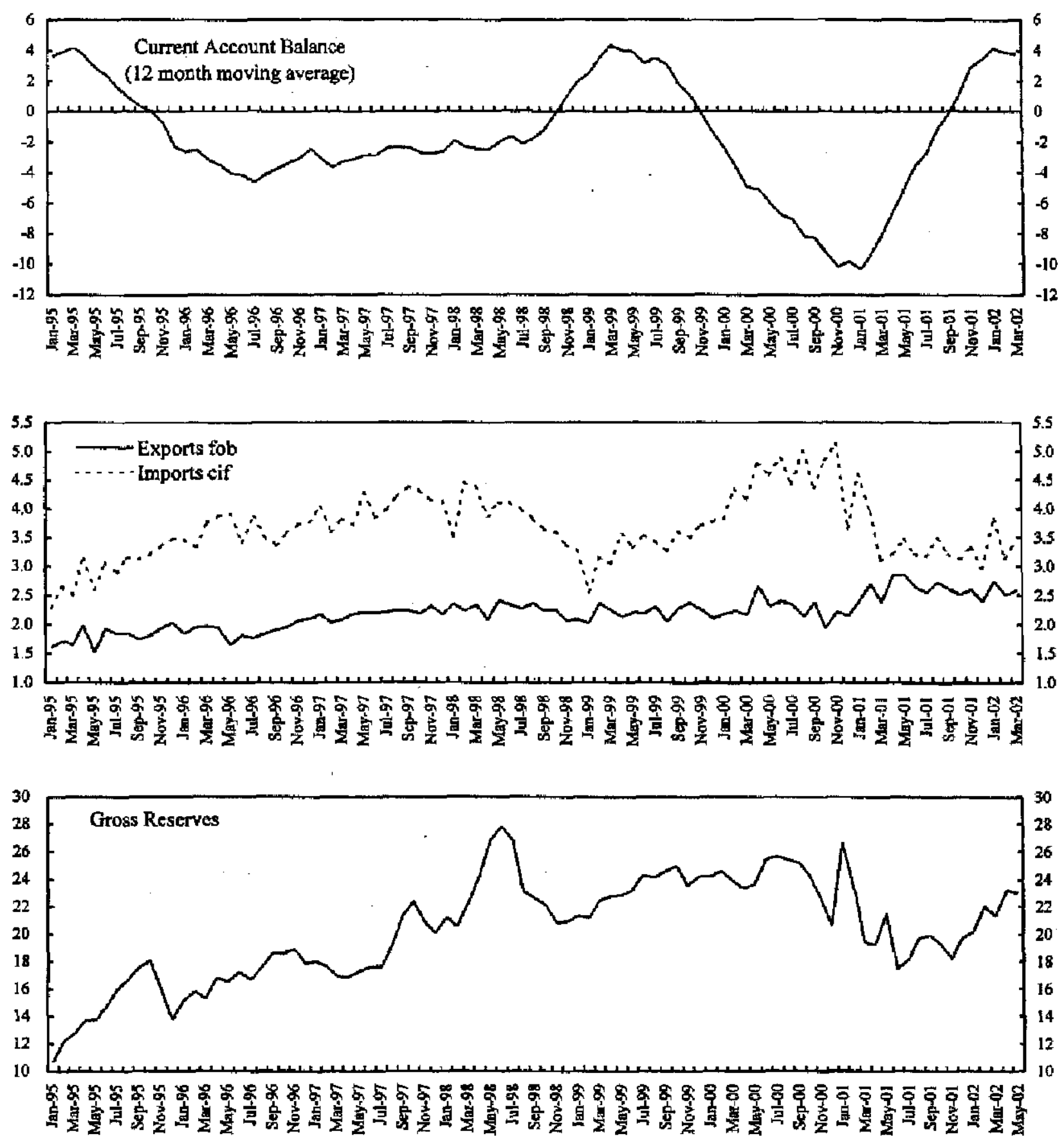

Sources: State Institute of Statistics; and IMF, International Financial Statistics. 
possible until this fall. However, the authorities have taken immediate action, including approving a road map of events leading to the privatization plan and initiating a new valuation of the company, to make the revised timetable feasible.

4. More generally, with the exception of privatization, the authorities are making good progress with their ambitious structural reform program (Annex B of the Letter of Intent):

- Although the banking system remains under stress, reforms have continued. The private bank recapitalization exercise has faced only minor delays, and is expected to be completed by end-August. State bank performance has improved markedly, and operational restructuring is well advanced. The SDIF has continued to make progress in resolving the remaining four banks under its control.

- The authorities have also made progress in the related area of corporate debt restructuring. In early June, the Istanbul Approach started to become operational, with financial institutions signing a Framework Agreement for debt workouts. The BRSA has followed this up by issuing supporting regulations for the provisioning of restructured loans, in line with international best practice.

- Further advances have been made on public sector reform. Beyond the abovementioned advances in public procurement and indirect taxation, the authorities have compiled final estimates of redundancies (some 46,000 identified positions) in SEEs.

- In contrast, privatization continues to disappoint. The second public offering of POAŞ (the petroleum distribution company) has been the only significant actual sale so far this year, and the third public offering of TÜPRAŞ (oil refinery) scheduled for the second quarter has been delayed. Preparations for the privatization of Türk Telekom, electricity assets, and gas companies have also been delayed.

5. With generally strong policy implementation, the program delivered encouraging results up until end-April (Figures 4-6). Benchmark bill rates fell well below (conservative) program projections, and the maturity of government debt was extended. Turkey also tapped international markets successfully, with total issues of US\$2.2 billion so far this year, compared with the program assumption of US\$3 billion for the year. With low inflation outturns through April, inflation expectations fell markedly-to 37 percent for end2002-allowing the CBT to cut its overnight rate in four steps to 62 percent compounded at end-April, from 80 percent in mid-February. Meanwhile, the Turkish lira was broadly stable against the U.S. dollar. Finally, on the growth side, various indicators, including industrial production, capacity utilization, business confidence, VAT receipts, and export growth have shown marked improvement in recent months, suggesting the beginning of an economic recovery. 
Figure 4. Turkey: Market Developments, 2001-02

(in percent; unless otherwise indicated)
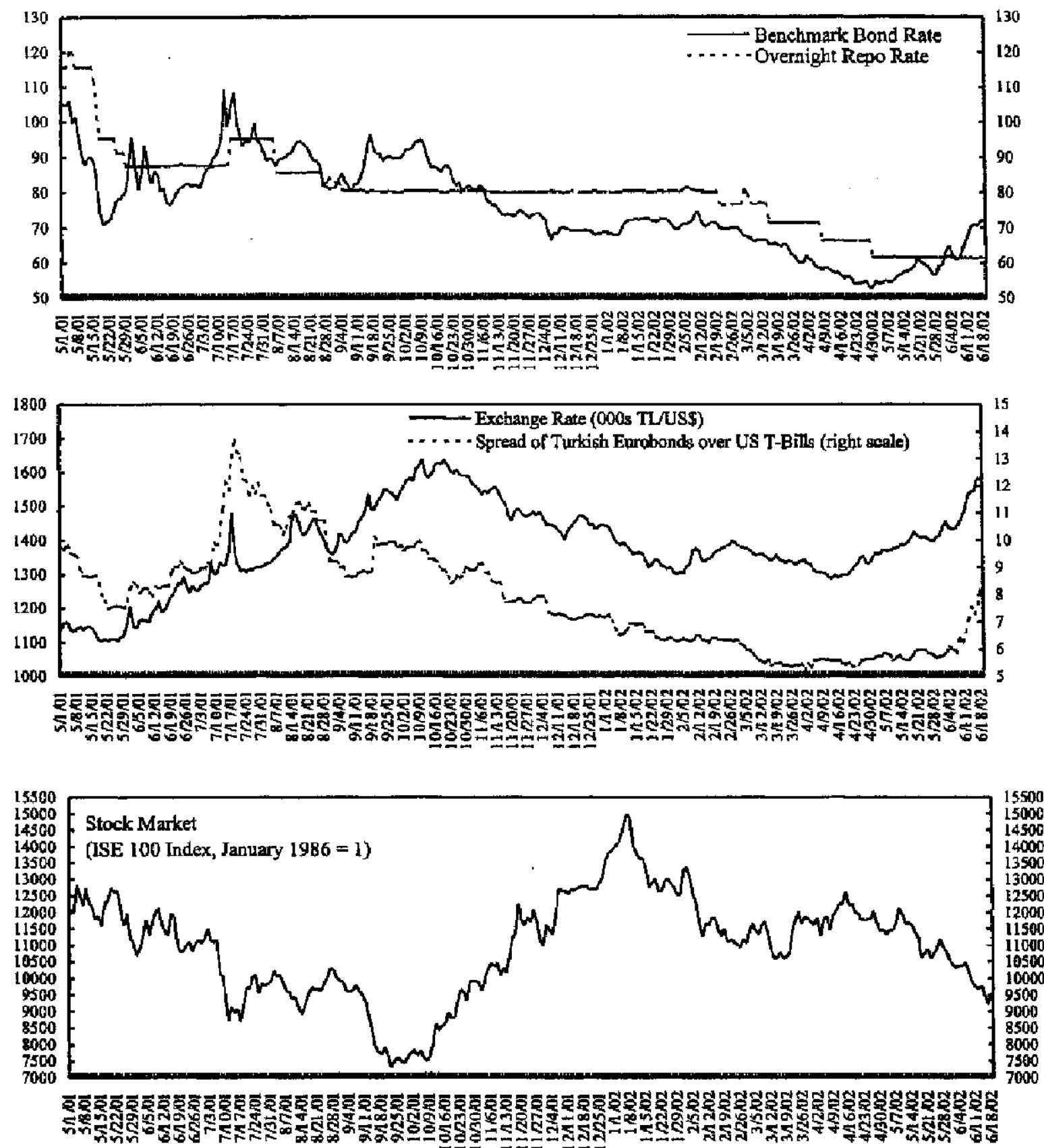

Source: Data from the Turkish anthorities. 
Figure 5. Turkey: Inflation, 1996-2002

(in percent)
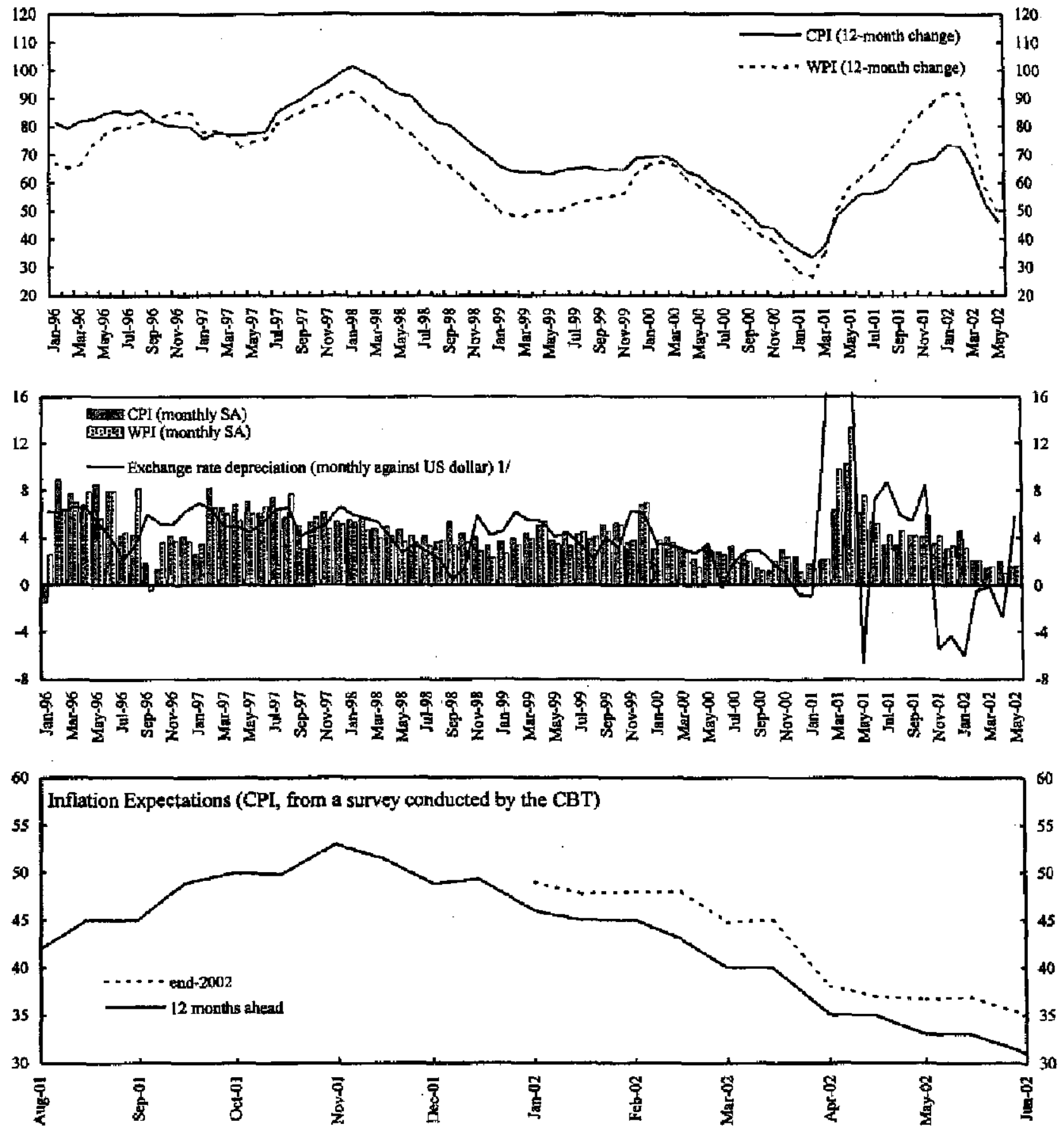

Source: Data provided by the Turkish authorities.

1/ In April 2001, the Ti/US dollar exchange rate depreciated by $29.5 \%$. 
Figure 6. Turkey: Output and Demand, 1996-2002

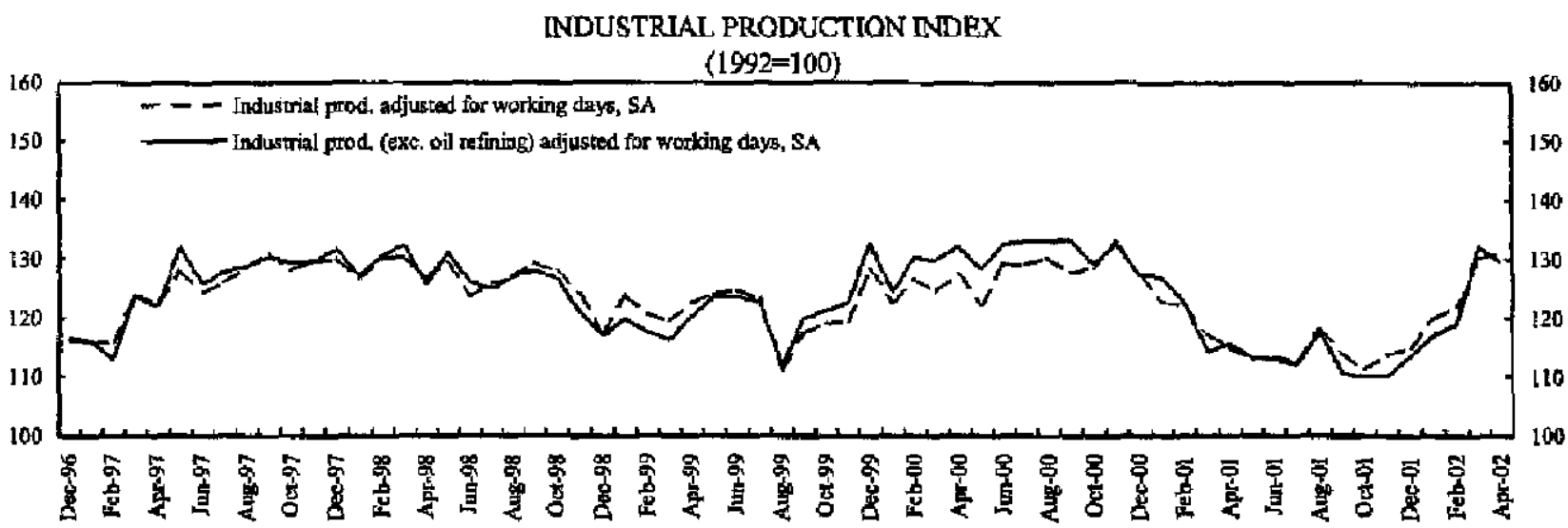

CAPACITY UTLLATION RATE

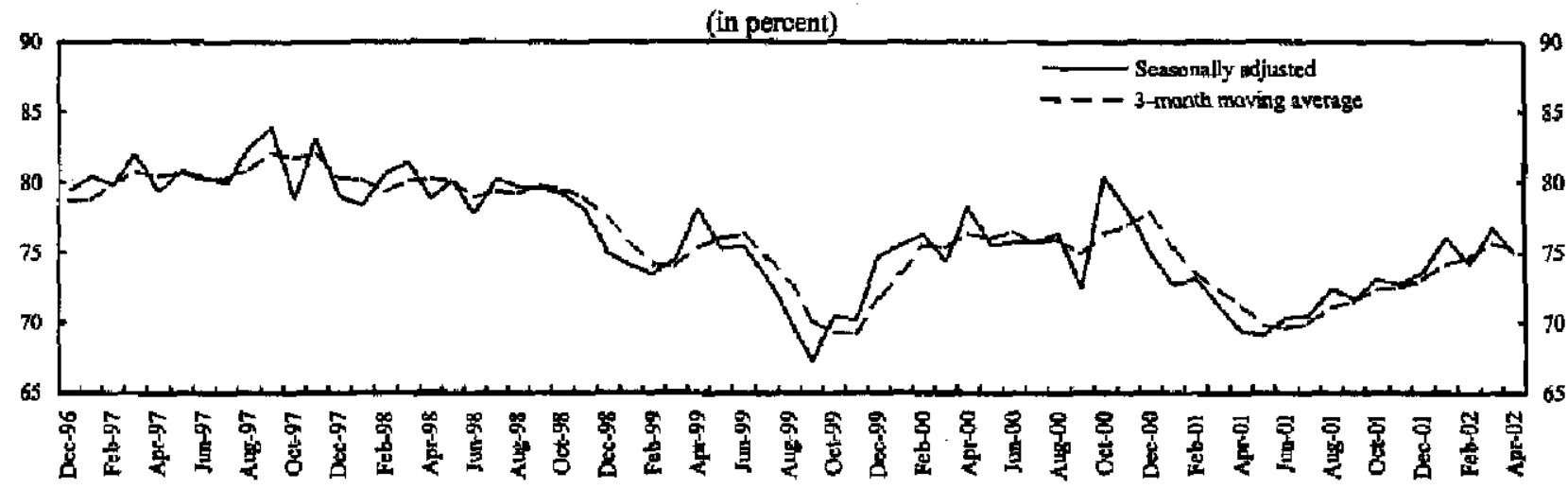

BUSINESS CONFIDENCE

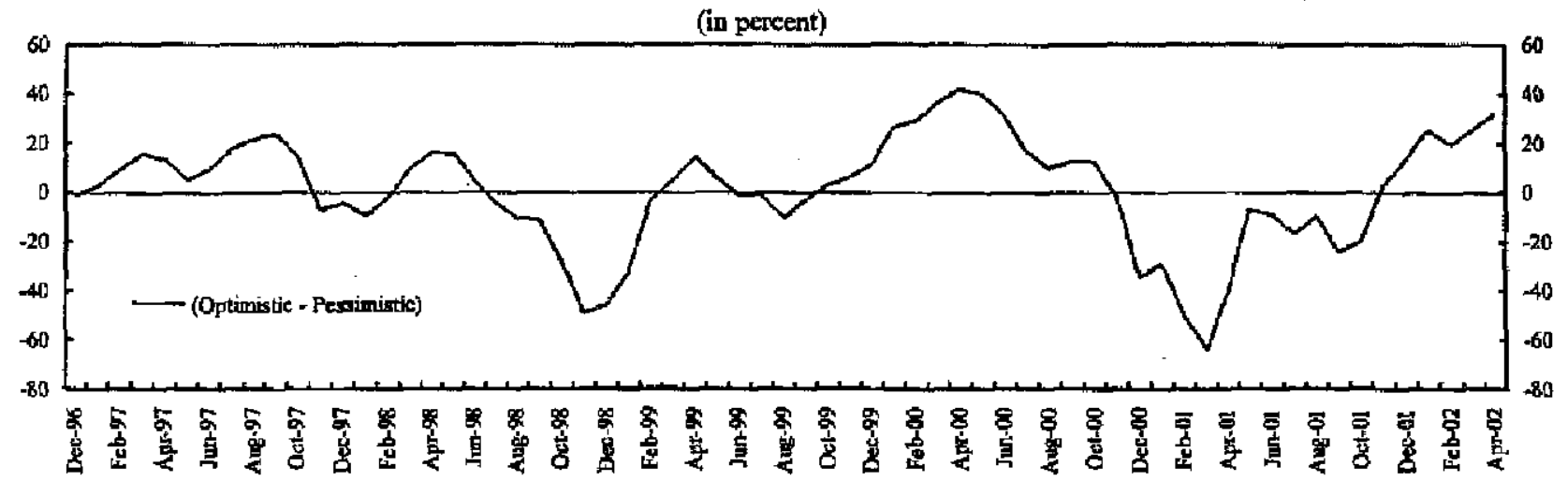

Soutce: Data provided by the Turkish authorities. 
6. Amidst increased political uncertainty, financial markets have since fallen back, although this has not yet affected activity or inflation. Since early May, concerns about the Prime Minister's health and the stability of the governing coalition have caused nervousness in financial markets. Between end-April and mid-June, benchmark bill rates rose by 18 percentage points, stock prices fell by 20 percent, and the Turkish lira weakened by 15 percent against the U.S. dollar. Also, after falling through April, the CBT's overnight borrowing position increased in May as banks increased their preference for liquidity. However, funancial market weaknesses bave yet to be reflected in indicators for the rest of the economy. CPI inflation in May fell to 0.6 percent month on month, helping end-year inflation expectations to fall to slightly below 35 percent. Recently released industrial production figures for April show a 14 percent increase year on year-the second successive month of strong performance.

7. While the new program has helped strengthen Turkey's resilience to economic shocks, key vulnerabilities remain. Strict adherence to the program has helped lower market rollover and debt sustainability concerns, and has contributed to a progressive strengthening of the financial sector and general improvement in external vulnerability indicators (Appendix III and Table 2). At the same time, the flexible exchange rate system has garnered greater acceptance and credibility in the eyes of market participants, acting as a useful shock absorber, while the CBT's standing has continued to improve on the back of the fall in inflation. Better-than-programmed developments also helped the government build up by end-April a cushion of TL 51/4 quadrillion in deposits at the CBT (although this has fallen to below TL 3 quadrillion by mid-June), while net international reserves have remained more than US $\$ 2$ billion above program over the past two months. Nevertheless, the domestic political environment is uncertain, regional instability is a threat, and the program will continue to test the coalition, especially if the economic recovery stalls. And, despite recent improvements, the financial system remains weak and public debt high, allowing policymakers little leeway.

\section{REPORT ON THE DISCUSSIONS}

8. After a successful start to the program, but with vulnerabilities remaining and against a backdrop of renewed financial market volatility, discussions focused on the need to continue with full implementation of the program to sustain its success. Both sides agreed that the program's good start had helped strengthen the economy's resilience to shocks, but noted that recent political uncertainty was having a sizeable impact on financial markets which could later hurt the economy. The staff emphasized that in light of remaining vulnerabilities it was important to avoid complacency, a key failure of past stabilization attempts. The authorities agreed, and reaffirmed their commitment to the program's ambitious macroeconomic and structural objectives. The CBT stressed that it would continue to pursue prudent monetary policies, in preparation for the early introduction of formal inflation targeting, and was confident that this year's inflation target would be met. The authorities also confirmed that the public sector primary surplus target of $61 / 2$ percent of GNP remained a central objective both for this year and next, as this would address a key 
vulnerability by helping to consolidate Turkey's improved debt sustainability prospects. The authorities also underscored the need to bring the bank recapitalization scheme to an early conclusion and to facilitate corporate debt restructuring, while also promising to press ahead with public sector reforms and privatization.

\section{A. Macroeconomic Framework}

9. The authorities and staff agreed that, despite recent financial market uncertainties, it would be premature to change the main macroeconomic targets ( $\mathcal{2}$ and Table 3): ${ }^{1}$

- With signs of a recovery increasing, the projection of 3 percent GNP growth for 2002 remained feasible. While the negative carryover from worse-than-expected fourth-quarter national accounts last year made it more difficult to meet this year's target, the improvement in both real sector indicators and business confidence strongly suggested that a moderate recovery had started in the first quarter, and looked set to continue. If the slowdown in real credit growth were to persist, this could eventually pose a threat to the sustainability of the recovery. However, both international and bistorical experience suggested that credit growth should not pose a constraint in the early stages of recovery (Box 1). Thus the staff agreed with the authorities that the 3 percent growth target for 2002 was attainable. ${ }^{2}$ However, if sustained, the impact of the recent increase in real interest rates would later need to be considered.

- Inflation was on track to meet the 35 percent target. Strict policy implementation, a stronger currency, and a steady decline in monthly inflation have enhanced the credibility of the disinflation effort, leading to a marked decline in inflation expectations. While increases in public sector prices and faster-than-anticipated currency depreciation remained risks, the authorities expected these to be offset by a larger-than-usual fall in agricultural prices over the summer, owing to a projected good harvest. There was even the prospect that inflation would end the year considerably below target, although this now seems unlikely in light of the recent depreciation. In any case, it was agreed that continued strong policy implementation would be key to ensuring that the end-year inflation target is met.

${ }^{\mathrm{I}}$ I refers to the relevant paragraph in the attached Letter of Intent.

${ }^{2}$ Outside observers are more pessimistic about growth prospects, but only marginally. In April, the OECD and EC arrived at estimates of $13 / 4$ percent and $21 / 2$ percent, respectively. In May, participants in the CBT business survey expected growth of $2 \frac{1 / 4}{4}$ percent in 2002 . The May consensus estimates are also for growth of $2 \frac{1 / 4}{4}$ percent in 2002 . 


\section{Box 1. Understanding Credit Developments in Turkey}

Turkey's recession has been marked by a sharp reduction in real private credit, raising the issue of whether credit growth, and the health of the banking system, are preconditions for renewed economic growth.

Even after correcting for measurement issues which understate the true stock of credit, the 2001 recession was still marked by a substantial decline in credit (Figure 7). Published credit aggrcgates exclude (i) nonperforming loans (which banks put into a "legal procecdings" account); (ii) loans transferred from intervened banks to the SDEF's collection department; and (iii) interest due (but not paid) on loans improperly classificd as performing. Adding back nonperforming and transferred loans (therc is insufficient data on accrued interest), the stock of real credit still fell markedly in 2001: 16 percent, as compared to the reported 25 percent

Both supply and demand factors have contributed to this sharp reduction in credit:

- Banks' lending capacity was limited by reduced funding. Although deposits remaincd on average altnost constant in real terms, syndicated loans from abroad were cut by almost half (about US\$8 billion) between late 2000 and end- 2001.

- Banks have shown a reduced witlingness to lend, in part because the recession and high real interest rates have reduced the number of creditworthy borrowers. While the financial sector's balance sheet has contracted by 3 percent in real terms, at 16 percent the drop in real credit to the private sector was much steeper.

- After suffering two financial crises in the space of three months, bank profitability and capital have been seriously weakened, reducing banks' ability to lend and to undertake risk. Depositors bave responded to the increased uncertainty by shortening maturities. In response, banks have increased their preference for liquid assets, as evidenced by the large stock of claims against the CBT, and reduced their appetite for private loans.

- The recession and the increase in real interest rates have reduced the demand for credit. Real lending rates (measured using 12-month ahead inflation) increased to around 30 percent in 2001 , compared to less than 10 percent in 2000. Consistent with this, survey evidence from the Chambers of Commerce (TOBB) showed that 87 percent of small firms and 66 percent of large firms did not expect to borrow in 2002.

- Corporate financial distress has worsened. Istanbul stock exchange data show that the number of companies at medium or high risk of default increased in the last two years. As a result, unless corporates can be made creditworthy (including through debt restructuring), fums will be forced to finarice themselves through retaincd carnings.

While both demand and supply factors play a role, cxpcrience from other emerging market countries generally points to a link between economic growth and restoration of credit flows. Among the Asian crisis countries, Korea's recovery has been strongest, and has been associated with an increase in real credit. In contrast, recovery in Thailand and Indonesia has been much slower, as too has been real credit growth, although part of this may reflect an adjustment to (lower) equilibrium levels of credit. For many Latin American countries, slower growth in 1999-2000 was associated with declines in real credit growth. ${ }^{l}$ The main exception is Mexico, where economic growth has accelerated since 1995 dcspite a sharp fall in real credit. However, much of Mexico's recovery has been in the traded sector, where firms can borrow overseas, using dollar receivables as collateral. In contrast, Mexico's nontradable sector has suffered a credit crunch and recovery has been slow. ${ }^{2}$

For Turkey, short-run growth should not run into financing constraints, but sustained recovery will likely depend on restoration of credit growth. Unlike in Asia, there is little evidence in Turkey of excessive bank finance: financial intermediation to the private sector is limited, with low private credit to GDP ratios due to crowding out by the government. Historical evidence and Granger-causality tests suggest that credit growth is more volatile than economic growth, and has typically followed cconomic recovery - that is, while the first slages of recovery can proceed without credit growth, sustained rccovery is ustally associated with more credit (Figure 8). However, unlikc Mcxico, only the largest Turkish firms have access to international capital markets, and even then typically require guarantees from domestic banks. Restoring credit flows will require successful bank recapitalization, lower financial intermediation costs, and-for there to be creditworthy bosrowers-corporate debt restructuring.

${ }^{1}$ Barajas and Steiner, "Credit Stagnation in Latin America," DMF Working Paper 02/53.

${ }^{2}$ Krueger and Tornell, "The Role of Bank Restructuring in Recovering From Crises: Mexico 1995-98," NBER WP No. 7042. 
Figure 7. Turkey: Credit Developments, 1999-2002
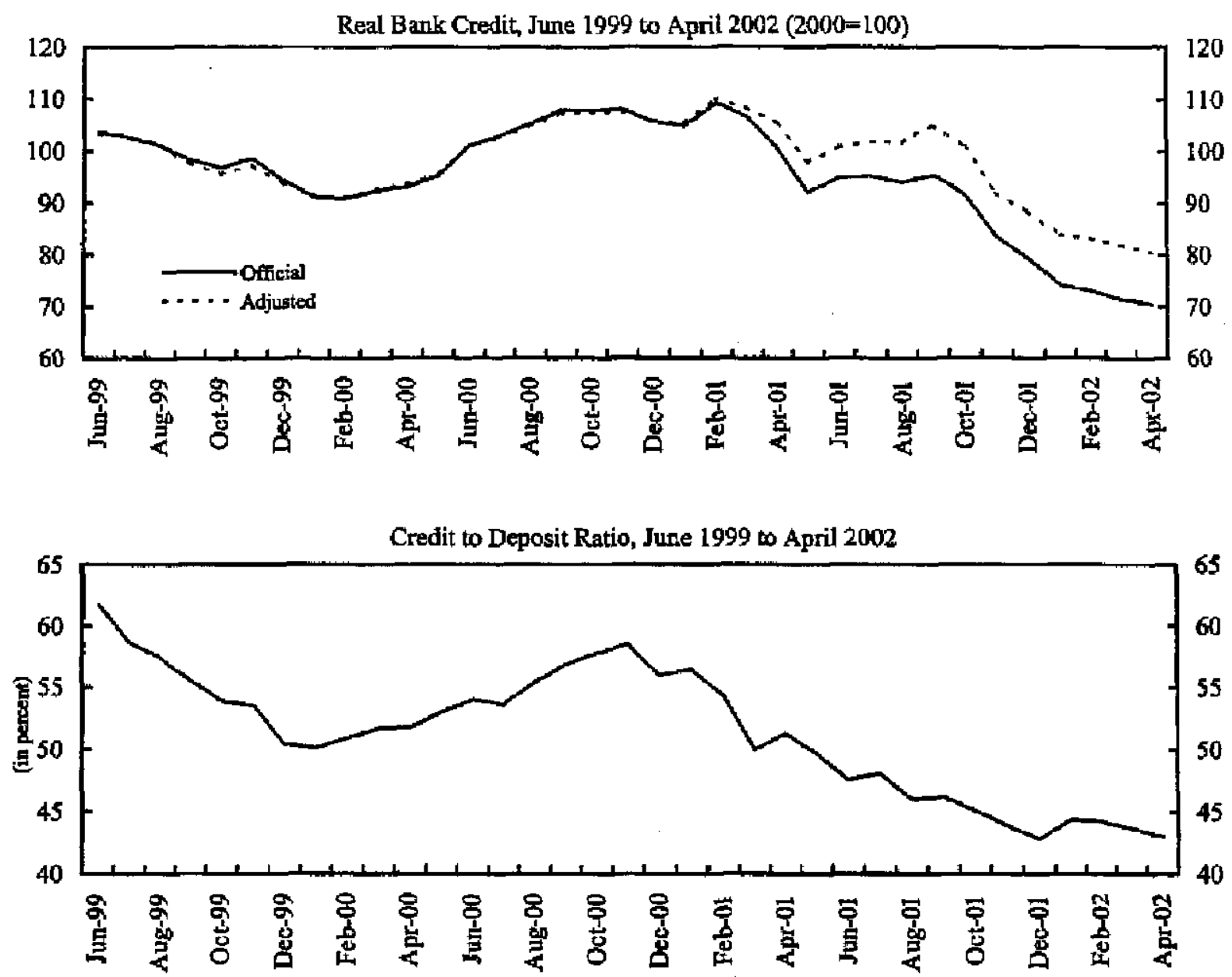

Real Bank Lending Rate, Jamuary 1999 to February 2002

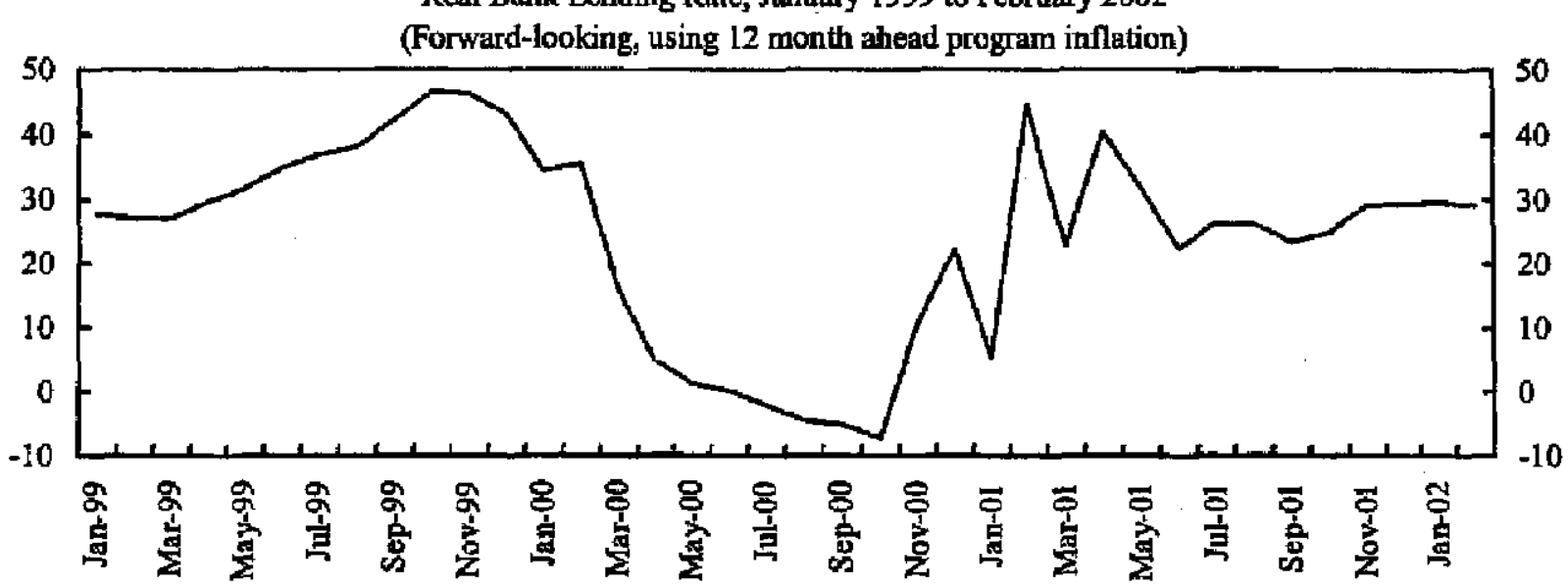

Source: Data from the Turkish authorities. 
Figure 8. Turkey. Real GDP and Real Credit, 1987-2001
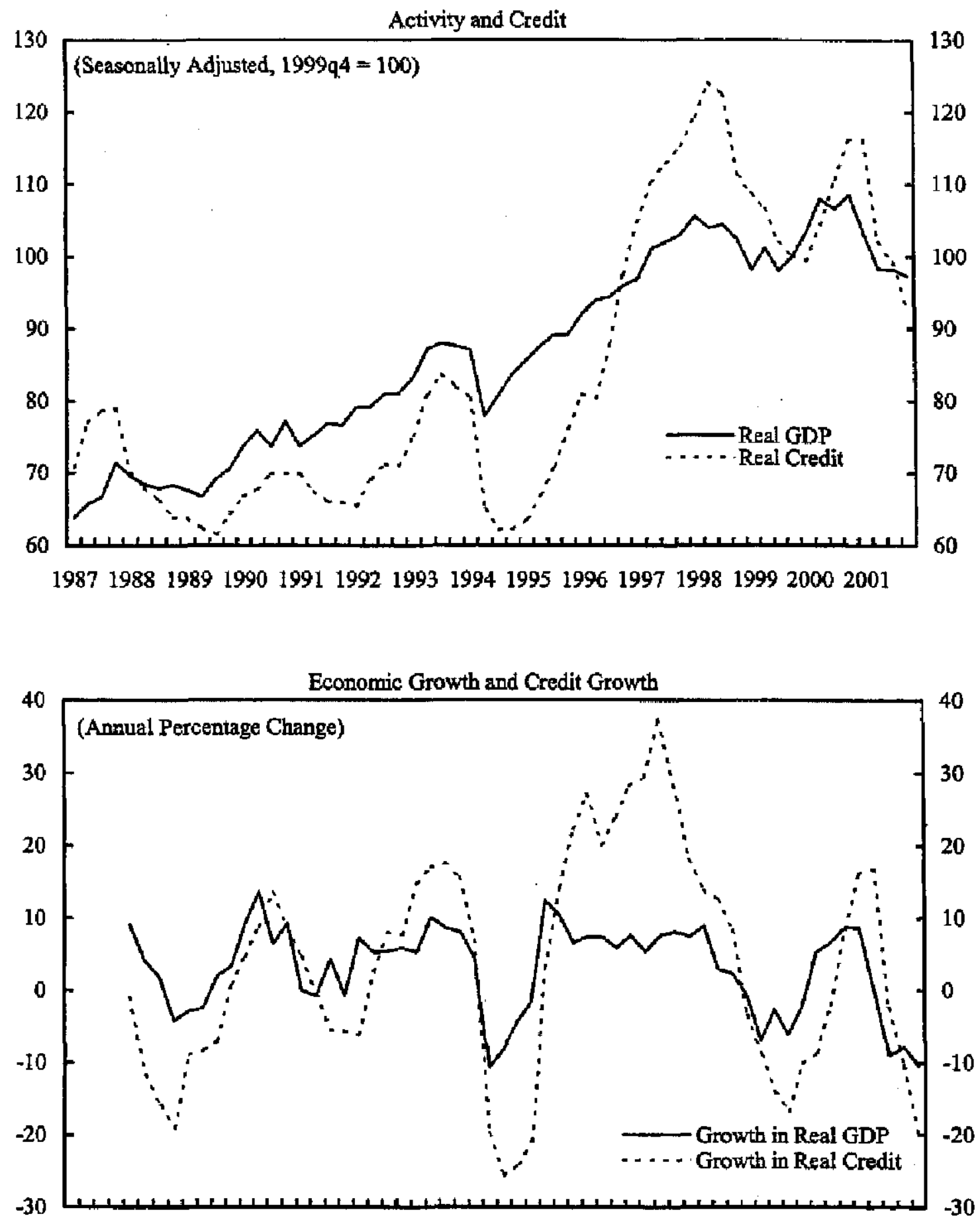

198719881989199019911992199319941995199619971998199920002001

Source: State Institute of Statistics. 
Balance of payments projections were also left unchanged from the first review (Table 4). During the first review, an improved capital account outlook allowed gross reserve estimates for 2002 to be increased by more than US\$1 billion relative to original program projections. This improved balance of payments outlook remains in place. The impact of higher oil prices is expected to be largely offset by stronger export growth, while a better services balance-due to brighter tourism prospects and lower projected interest payments-should outweigh lower-than-envisaged worker remittances. And, although individual capital account item projections have changed - improved bank flows, and lower net private sector flows and net errors-the overall balance is close to previous projections.

- Although the CPI-based real effective exchange rate has, until recently, continued to appreciate, the joint assessment was that competitiveness remained broadly adequate (Figures 9 and 10). Consistent with the findings of recent CBT surveys, exporter representatives indicated that the current level of the lira did not pose a serious threat to Turkey's export performance, but that renewed currency volatility would be problematic. Meanwhile, labor costs continue to be contained, with unit labor costs in U.S. dollars still well below their pre-crisis peak.

10. With interest rates and exchange rates still within program projections, this year's decline in the public debt ratio should be somewhat larger than programmed (Box 2). As in the original program projections made at the beginning of the year, there should be a sharp fall in the debt ratio in 2002 , as higher prices from the nominal depreciation in 2001 (which instantaneously increased the Turkish lira value of foreign currency debt) result in higher full-year nominal GNP only in 2002. On top of this, even taking into account recent setbacks, financial market developments in 2002 have been more favorable than anticipated, particularly for interest rates and the exchange rate. These have reduced projected interest costs and lowered the Turkish lira value of the foreign exchange linked debt stock. In light of these developments, and despite lower than expected privatization proceeds and cautious assumptions for interest rates on Turkish lira debt, the debt-to-GNP ratio is projected to fall to 77 percent by end-2002, compared to 81 percent in the original program. Over the medium term, Turkey's debt ratio is estimated to decline markedly, provided real interest rates decline moderately and the primary surplus remains strong. However, although debt sustainability assumptions appear robust to individual shocks - such as permanently lower growth, higher interest rates, and lower primary surpluses - a combination of such factors could produce an unsustainable path for public debt over the medium term. Moreover, the large portion of foreign exchange linked debt increases Turkey's vulnerability to real exchange rate changes, while making the debt dynamics less sensitive to domestic interest rate shocks.

11. In light of remaining vulnerabilities, the discussions covered key program risks and possible responses. Recent financial market nervousness served as a reminder of the program's vulnerability to domestic shocks. A major external shock, such as a large military campaign in the region, would also test the program. The latter would most likely entail 


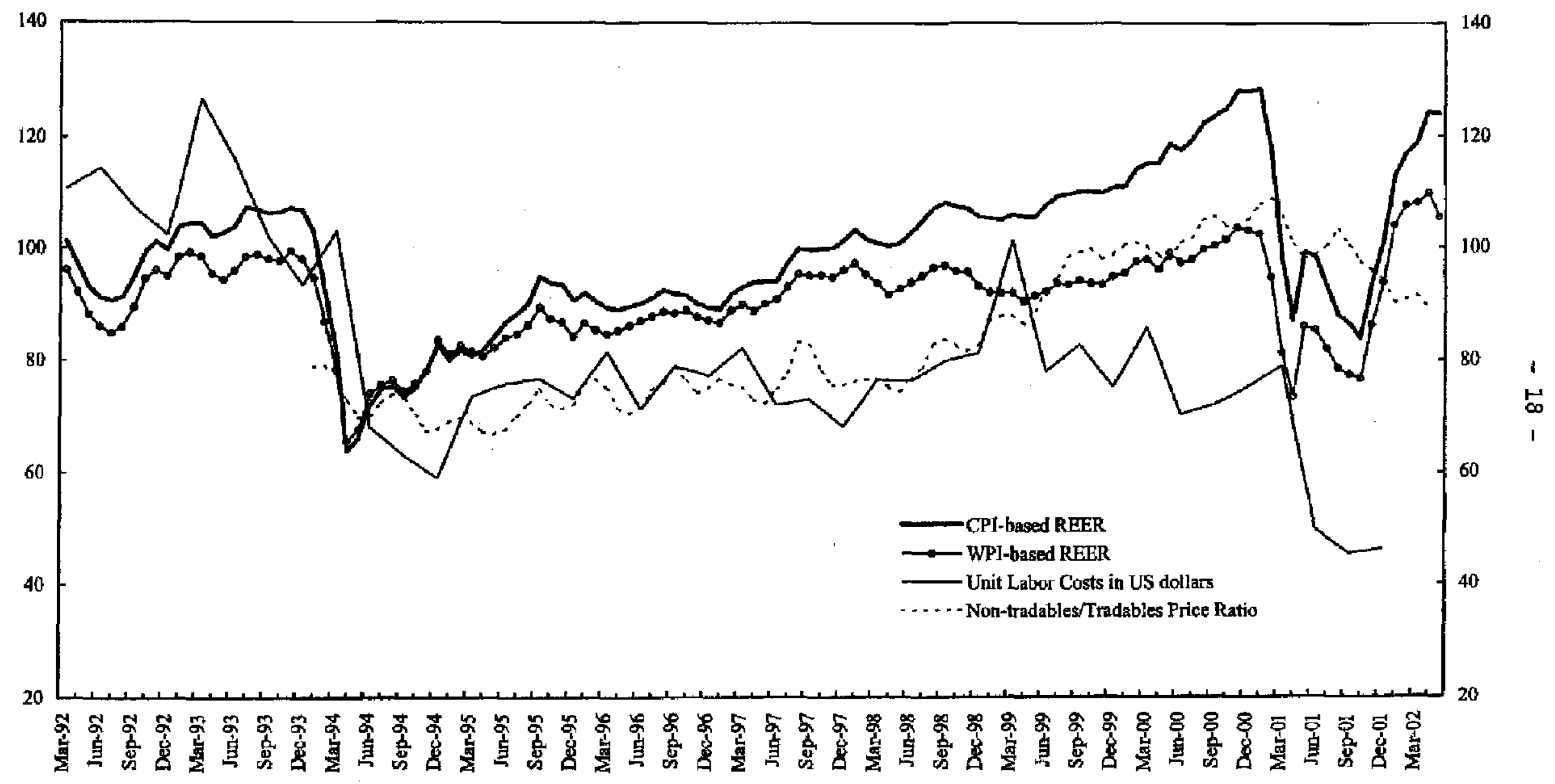

Sources: Data from be Turkish authorities; and Fund staff estimates.

li As of April 2002. 
Figure 10. Turkey: CBT Tendency Survey Findings, Export Prospects for the Second Quarter of 2002
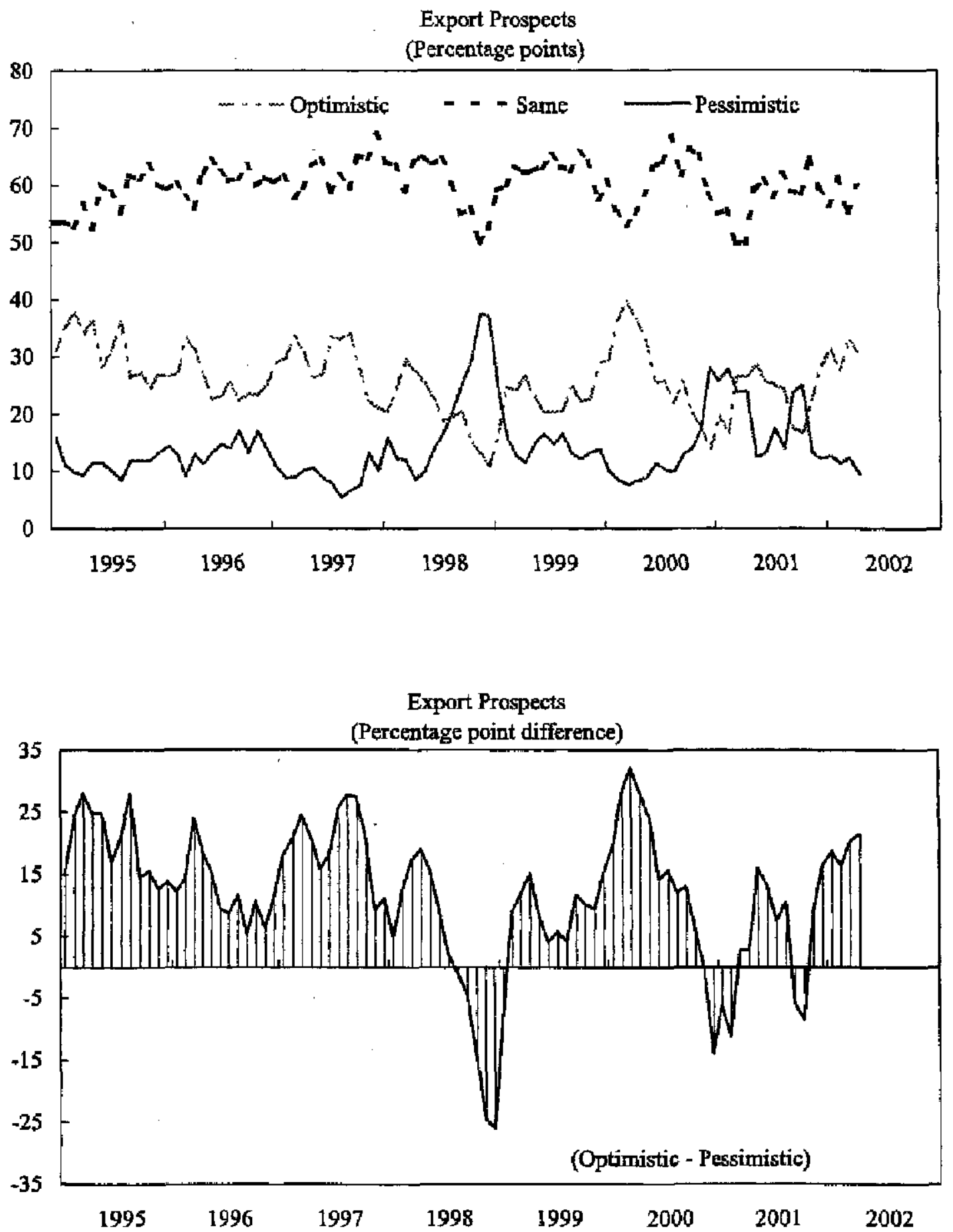

Source: Central Bank of Turkey. 


\section{Box 2. Turkey's Public Debt Dynamics}

By end-2001, net debt of the overall public sector reached an estimated 93 percent of GNP, up from 58 percent of GNP at end-2000. As discussed in previous staff reports (for example, Box 2 of the January staff report for the SBA, EBS/02/8, 1/18/02), the increase in the debt stock mainly reflects the one-off recapitalization of state and SDIF banks and the impact of the devaluation on Turkey's foreign exchange linked debt. In addition, last year's real output decline, through its effect on the denominator alone, increased the debt-to-GNP ratio by over 7 percentage points.

While many analysts focus on central government debt, assessing Turkey's debt dynamies requires a broader concept of net debt incorporating the assets and liabilities of the rest of the public sector (Table 5). State enterprises, extrabudgetary funds, and local governments have in the past received large amounts of external project financing with Treasury's guarantec; these loans now account for a significant portion of the central government's external debt service. At the same time, public sector indebtedness would be overstated if Treasury's debt held within the public sector were not taken into account. Beginning in 2000 , the Unemployment Insurance Fund (UIF) has channeled its primary surpluses mainly into treasury bills and reinvested the interest income. The UTF's assets are expected to grow further over the next several years. More significantly, the CBT's net domestic claims on the Treasury amounted to nearly 17 percent of GNP at end-2001. Interest from those claims contributes to CBT profits which are transferred to the Treasury annually. Consolidating the assets of the CBT and UIF with the debts of the central government provides a more complete picture of net public sector debt.

The decline in the public debt ratio in 2002 and over the medium term is now expected to be even larger than programmed. As under the original program, a sharp fall in the debt ratio is expected in 2002 , largely reflecting the one-time effect of the nominal depreciation in 2001 . $^{\prime}$ However, favorable financial market developments in 2002 , particularly for interest rates and the exchange rate, have reduced projected interest costs and lowered the Turkish lira value of the foreign exchange linked debt stock, improving debt prospects for end-2002 and beyond (Table 6). Despite cautious assumptions for real interest rates on Turkish lira debt for the remainder of the year, the debt-to-GNP ratio is projected to fall to 77 percent, compared to 81 percent in the original program. Continued strong public sector surpluses and moderate declines in real interest rates are also expected to help lower the debtto-GNP ratio over the medium term, to the low 60s (Table 7).

While debt sustainability (that is, a declining stock of debt relative to GNP) is robust to a range of macroeconomic disturbances, a combination of several shocks could jeopardize the medium-term debt outlook. Annual growth at $1 \frac{1}{2}$ percentage points below the baseline would still result in a stabilizing debt dynamic, albeit with an increase in the debt stock relative to the baseline of about 5 percent of GNP by 2006 (Figure 11). Likewise, higher real interest rates of 5 percentage points above the baseline raise the debt stock by 7 percent of GNP by 2006 , as would a primary surplus of 5 percent of GNP (instead of the program's $6 \frac{1}{2}$ percent) over the medium term. A real exchange rate 10 percent weaker than the baseline would increase the debt stock in 2002 by 5 percentage points, and by a further 2 percentage points above the baseline by 2006 if the weakness in the real exchange rate persists. But none of these shocks in and of itself changes the dynamic toward sustainability. However, in a worse case scenario, a combination of poor fiscal performance, low growth, high interest rates, and a weaker exchange rate would produce an unsustainable path for public debt over the medium term.

${ }^{1}$ As highlighted in previous staff reports, conventional debt-to-GNP ratios overstate the rise in debt when inflation increases following a devaluation (as in 2001), and the fall when inflation declines. One simple way to correct for this bias is to use a measure of GNP that is centered around the end of the year. Indeed, using centered GNP, the debt ratio increases by less in 2001 (from 52 percent to 76 percent), and falls by less in 2002 (from 76 percent to 67 percent) than when using anmual GNP. 
Figure 11. Turkey: Public Debt Sensitivity Analysis, 2001-06
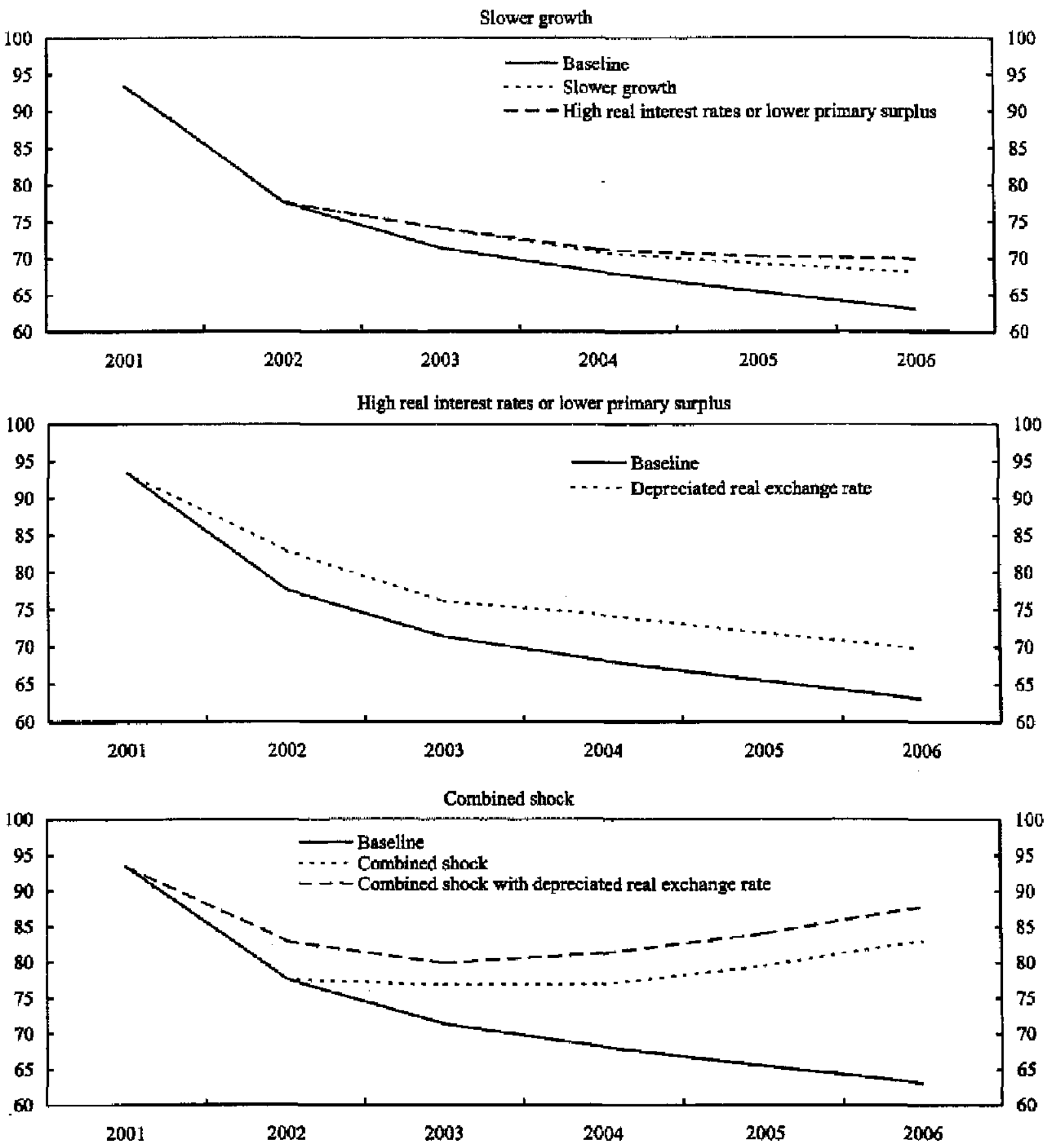

Source: Data from the Turkish authorities. 
capital outflows, lower tourism revenues, higher interest rates, and renewed rollover concerns, together with sharply higher oil prices. While developments in the first part of the year had strengthened budget financing prospects for 2003, the outlook remained vulnerable to a weakening of market confidence. This could result in a sustained increase in interest rates and a shortening of maturities for new borrowing, triggering renewed rollover difficulties. Both sides agreed, however, that the design of the program, and in particular the floating exchange rate and the strengthening of the banking system, left the economy less vulnerable than before. Continued strong policy performance and use of any favorable market opportunities to build up cushions for international reserves and government financing would further increase the economy's resilience to future shocks. Speedy and clear resolution of the recent political uncertainty could make a crucial contribution to restoring financial market confidence.

12. Although Fund exposure remains very high, the macroeconomic framework indicates that Turkey should be in a position to discharge its obligations to the Fund in a timely manner (Tables 8 and 9). Turkey's unblemished record of payments to the Fund, the authorities' commitment to their reform program, continued favorable access to international capital markets, and better-than-projected reserves buildup all provide assurances in this respect. Turkey's obligations to the Fund will, however, continue to be substantial over the medium term, with payments to the Fund projected to peak at about US $\$ 91 / 2$ billion, or 14 percent of exports of goods and nonfactor services, in 2006 . Turkey's capacity to repay the Fund will therefore need to be monitored closely, and corrective measures will be called for if projections turn out less favorable than expected.

\section{B. Fiscal Policy and Supporting Reforms}

\section{Owing to additional measures to offset weaknesses in SEEs, the authorities} remain on track to meet the $\mathbf{2 0 0 2}$ public sector primary surplus target of 6.5 percent of GNP ( 95 and Table 10):

- While commending the authorities on continued strong fiscal outturns, the staff noted a number of concerns. The staff welcomed the authorities' resolve to stick to fiscal targets, and noted that their ability in the past to take decisive measures to correct emerging deviations had played a large role in helping them to meet targets. The staff also noted that the authorities would need to draw on their resolve once more, since the buffer provided by central government overperformance could soon be more than offset by underperformance at SEEs, where margins had been squeezed by rising energy prices and delays in raising administered prices. The fiscal program had been further pressured by unforeseen reversals and shortcomings in expenditure measures: a generic drug program and the elimination of electricity discounts had been delayed, regional directorate closures did not yield significant savings, and investment spending in SSK (a social security fund) could not be cut as planned. Finally, overruns were projected in the civil service pension fund, and the authorities bad decided to increase foreign-financed investment spending. While for the full year 
revenue overperformance would largely offset the impact of expenditure pressures, SEE underperformance-if not addressed-would result in a gap of about $1 / 2$ percent of GNP relative to the 2002 public sector primary balance target.

- The authorities agreed with this assessment, and decided to take further measures to eliminate the projected fiscal shortfall. They would institute an upfront catch-up of administered prices in May-July (with an estimated first-round impact on the CPI of $1 \frac{1}{2}-2$ percent), and follow with a renewal of the neutral price change strategy for SEEs (setting prices to closely track WPI inflation). They would also scale back some of the intended increase in investment spending. Moreover, to improve the underlying performance of SEEs, the authorities indicated their intention to revise the law governing SEEs to improve the independence of their Boards of Directors, and to clarify their financial relations with the government. The authorities also thought it useful to review the coverage of the fiscal performance criteria, once more data on SEE performance became available later in the year. The staff welcomed these initiatives, although their benefits would be felt only from next year on.

14. For 2003, the authorities reaffirmed their commitment to maintain the public sector primary surplus at 6.5 percent of GNP ( $(6)$. They agreed that fiscal policy should not be loosened, given Turkey's medium-term debt dynamics and the need to roll over debt in 2003 without a large international assistance program. To help maintain a prudent fiscal position, the autborities intended in the budget call in June to provide line agencies with indicative constant real expenditure ceilings, thereby preserving flexibility in preparing the budget. The staff urged that effort also be devoted to improving the composition of fiscal adjustment in 2003 , in view of reversals experienced in 2002 . The staff highlighted the need for a reduction in agricultural and industrial subsidies, and for an appropriately restrained wage policy, consistent with the programmed inflation path.

15. Fiscal adjustment is being supported by the improved budget management foreseen under the program:

- Indirect taxation has been reformed (ף17). The Special Consumption Tax (SCT) Law, enacted on June 6, encompasses all excise taxation of goods. With this legislation, multiple excises on the same product are consolidated, reducing taxpayer compliance costs and increasing transparency. Analysis by the staff, authorities, and World Bank suggests that the legislation is revenue neutral. Discussion revolved around the need to eliminate earmarking of SCT proceeds. To enhance financial management, the authorities agreed to remove earmarking starting with the 2003 budget. This will be achieved through a separate Council of Ministers' decision (a new structural benchmark for end-August).

- Revenue administration reforms have been initiated. The authorities explained that they had designed a new functional structure for their tax administration that 
would include units to deal with tax policy, taxpayer services, and tax audit coordination. Much work, however, remains to be done to operationalize the various units, and an additional unit for internal audit will need to be added. The authorities had also already begun to assemble the information necessary to specify an audit plan. The staff noted that the efforts to improve revenue administration were critical, particularly given the authorities' intention to exempt new infusions of capital into banks and corporates from tax investigation. The authorities viewed this step as necessary to help raise funds for the bank recapitalization exercise, but agreed with the staff that it would tend to erode future tax compliance. The staff took strong exception to this proposal, and urged the authorities, at a minimum, to apply a meaningful fee to newly registered assets to avoid a complete loss of taxes due and to limit the darnage to future compliance. The authorities argued that any income underlying the assets would still in principle be taxable through other investigative routes. They would also aim to close loopholes in the definition of taxable income, expand the use of indirect assessment methods, and shift the burden of proof in tax investigations to the taxpayer. This would help improve taxpayer compliance. Finally, the authorities stressed that all declared funds would be subject to investigation for money laundering.

- The Public Procurement Law has been amended (meeting a prior action), and steps have been taken to operationalize the procurement agency (ๆ19). The amendments reduce the thresholds in the law originally passed in January 2002 by as much as 75 percent, and extend bidding times to 25 days for tenders falling below thresholds. The procurement agency has issued bylaws that enhance its revenue collection capability and that regulate its employment (in particular by allowing it to immediately recruit more qualified staff). The authorities indicated that if resources and staff could be put in place soon they would be able to complete all necessary secondary legislation to allow the law to become effective on January 1,2003 , as envisaged.

- $\quad$ Streamlining of SEE staffing is getting underway ( $(18)$. In May, sharpening earlier preliminary estimates using a methodology focused on idle production capacity, SEE management and external auditors produced a final redundancy estimate by company and position (45,792 in total as of end-January 2002). Discussion revolved around how best to manage the redundancy process moving forward. The authorities noted that they had agreed a protocol with unions allowing voluntary retirements, transfers to other public sector institutions and, in the last instance, forced lay-offs. The staff and the authorities agreed that any transfers would not increase total programmed public sector employment, and would be contingent on transferred staff having appropriate qualifications. Given line ministry hiring plans, this would limit transfers of workers to the budget to about 2,300 . The staff and authorities also agreed not to modify the adjuster on severance pay (net retrenchment costs of up to TL 1.25 quadrillion are excluded from the program's primary surplus calculation), 
pending further investigation by the authorities of the possibility of extending the staff reduction program to the civil service.

- The authorities had continued to make good progress in improving debt management. Strong demand for T-bills, reflected in private sector rollover rates of more than 100 percent through end-April, bad allowed the Treasury to extend the maturity of its domestic debt while interest rates fell. This, and the cushion in government deposits at the CBT built in the early part of the year, had helped the Treasury to meet the budget financing requirements relatively easily even since the beginning of May when financial market conditions weakened. In addition, the coordination between the Treasury's borrowing program and the CBT's monetary policy had continued to improve. A comprehensive study on debt strategy and risk management was underway to be completed by end-June, with the assistance of the World Bank. The study will provide the basis for further improvements in the organizational and legislative structure of debt management.

16. The staff and the authorities reviewed the current state of fiscal management more generally, and noted that fully implementing existing Fund-and Bank-supported programs would address most identified weaknesses. The findings of this review are presented in a Fiscal Management Assessment report which is being issued as a supplement to this report. The report emphasizes the importance of addressing existing weaknesses, and points out that these had adversely affected fiscal policy design and implementation, contributing to high debt levels and to macroeconomic vulnerability. The authorities agreed with the thrust of the Fiscal Management Assessment, and stressed their intention to fully implement their program of public sector reform. The staff and authorities also agreed that several of the FMA's key recommendations could be addressed in the new budget systems law (whose submission to parliament is a structural benchmark for end-June).

\section{Monetary Policy}

17. Monetary policy continues to be guided by the inflation target, consistent with the program's base money ceilings ( $(7$ and Tables 11 and 12). With the exchange rate strengthening, and inflation expectations for end-year close to the official target, the СВT was able to lower short-term interest rates on four separate occasions since February. However, since the most recent interest rate reduction, at end-April, was followed by a weakening of the exchange rate and higher treasury bill rates-most likely reflecting political uncertainty, rather than monetary policy concerns-both sides agreed that continued caution was needed. The CBT reaffirmed that it would introduce inflation targeting later this year, emphasizing that technical preparations in modeling and forecasting were well advanced.

18. The authorities and the staff agreed that the new foreign exchange purchase auctions had succeeded in the goal of reserve accumulation (18). Following the introduction of daily foreign exchange auctions of US $\$ 20$ million in April, the daily maximum auction amount was raised to US $\$ 40$ million in May, to compensate for days 
where insufficient bids were received. The staff supported the CBT's plan to contimue the purchase auctions, at least while the balance of payments remained strong. The staff also welcomed the introduction of regular one-month deposit auctions, which had sterilized the monetary impact of the foreign exchange auctions and helped establish a more reliable yield curve.

\section{While welcoming the authorities' recent moves to lower financial transactions} taxes, the staff noted that intermediation costs continued to be high ( $₫ 9$ ). In May the CBT extended remuneration to cover all required reserves. It also lowered the remuneration rate to 22 percent from the 26 percent (effective rate) introduced in August 2001, in line with the decline in market interest rates. The Ministry of Finance was also completing legislation to remove some nuisance transactions taxes, which raised little revenue but hindered market development. However, the staff and private sector representatives noted that intermediation costs would still be high-interest withholding taxes of up to 20 percent, a 5 percent bank and insurance transactions tax, and a levy of 10 percent of interest income on bank loans. In addition, the tax system was biased in favor of government debt and against the creation of private debt markets. The authorities reaffirmed their intent to reduce these distortions in the context of the direct tax reform later this year, but noted that the scope for tax reductions would be restricted by the program's fiscal targets

\section{Financial Sector Reforms ${ }^{3}$}

20. Implementation of the program to strengthen the core private banking system, including through the use of public money to assist in recapitalization, was now at a critical stage ( $(10$ and Table 13). The three-stage audit assessment exercise conducted by the independent auditors and the BRSA between January and May 2002 to determine the capital positions of banks had revealed significant underreporting of nonperforming loans. In midJune, the BRSA notified individual banks of the results of their assessments (Box 4), and the banks were given until early July to call shareholder meetings to raise necessary capital. The recapitalization, done either by shareholders alone or with SDIF support where applicable and needed, would be completed in time to be reflected in August 2002 balance shects. The BRSA reiterated its readiness to intervene in any bank unable to meet its capital requirement - and demonstrated its strong commitment by taking over on June 19 the country's fifth largest private bank, Pamuk, which the audits showed to be deeply insolvent. (On the same day, the BRSA also took over Pamuk's shareholder rights at Yapi ve Kredi Bankasi, the third largest private bank which is solvent, and changed two members of Yapi ve Kredi Bankasi's executive board.) The authorities recognized the importance of preserving market and depositor confidence during this critical phase of the recapitalization,

\footnotetext{
${ }^{3}$ Box 3 provides a summary of the coverage and status of structural conditionality in the program, areas covered by World Bank lending and conditionality, and structural measures not included in the program,
} 


\section{Box 3. Structural Conditionality}

\section{Coverage of structural conditionality under the three-year Stand-By Arrangement}

The program aims at reinvigorating structural reforms, while incorporating those policy actions that were already agreed under the previous program (as set out in Table 2 of the November 20 Memorandum on Economic Policies and Annex B of the Letter of Intent attached to EBS/01/192, 11/21/01). The main areas covered by the program's structural conditionality continue to fall into two categories: (i) measures with a direct and significant bearing on the attainment of macroeconomic stability, which include extensive conditionality in the banking sector, the key source of weakness underlying the recent crises; and (ii) measures that will improve medium-term growth prospects, which, in addition to banking reforms, include measures to strengthen tax policy and expenditure management, and steps to facilitate corporate restructuring and to enhance the role of the private sector in the econony. Since Turkey's problems largely reflect a lack of confidence stemming from structural weaknesses in the economy, the eredibility of the program depends fundamentally on the strength of the structural effort. In addition, structural conditionality has beev introduced in the context of the IMF safeguards assessment to improve further the transparency and effectiveness of the CBT's control, accourting, reporting, and auditing systems.

\section{Status of structural conditionality from earlier programs}

Previous programs featured key structural conditions, many of which were prior actions for program reviews (see EBS/01/69, 5/7/01). Comprehensive structural reforms focused on banking sector restructuring, fiscal transparency, private sector development, and governance. While privatization proceeded rather slowly, in part owing to weak market conditions, major progress was made in other areas. All key structural conditionality from previous programs has been met, except for the adoption of a privatization plan for Türk Telekom. This was set in the eighth review of the previous SBA as a structural benchmark for end-December, but has yet to be completed.

\section{Structural areas covered by World Bank Lending and conditionality}

The key element of the World Bank's program Jending in 2001 was the Public Sector and Financial Sector Adjustment Loan (PFPSAL) approved in July 2001. The PFPSAL program is focused on banking and public sector reforms to support the quality of fiscal adjustment and modernization of the public sector. A follow-up three-tranche operation (PFPSAL II) was approved in April 2002. The Bank's program lending also supports structural reform to promote private sector development and the strengthening of the social safety net. The Economic Reform Loan (ERL) covers reform of the energy, agricultural, and telecommunications sectors, as well as privatization and structural fiseal reforms. The Agricultural Reform Implementation Project (ARIP) supports implementation of the agriculture reform program, including the introduction of a direct income support program for farmers. The Social Risk Mitigation and Privatization Social Support projects help Turkey's efforts to improve its social protection system and alleviate the social costs of the crisis.

\section{Other relevant structural conditions not included in the proposed program}

An area that is not coveted by program conditionality is trade regime and policy, given that Turkey's trade regime is only moderately restrictive. On privatization, the program does not include upfront conditionality on actual sales of specific enterprises. Instead, Fund and World Bank conditionality is aimed at preparing the ground for rapid privatization once market conditions improve as expected in 2002. However, to help monitor overall progress in privatization, indicative targets have been introduced for privatization proceeds. 


\section{Box 4. Capital Adequacy of Turkish Private Banks}

The just-completed three-stage audit of the capital adequacy of private banks has been at the heart of the BRSA's efforts to strengthen the core private banking system. To ensure the integrity of the process, the audits were conducted in three stages. First, independent extemal auditors assessed banks' capital needs using new BRSA guidelines established in line with international best practice. Second, the BRSA appointed third-party reviewers to check that the external auditors had accurately followed the guidelines. The BRSA then made its third and final assessment, incorporating additional information from reports made by BRSA's own on-site examiners.

The audits focused on four key areas. Capital adequacy-detailed information was requested on all classes of assets, the application of market risk, and verification of the source of funds for any recent injection of capital. Quality of credlt and other receivables—extensive disclosure of (i) borrowers' performance; (ii) ability and willingness to pay; and (iii) risk classification (five categories) was required. Auditors had to certify that credit risk had been individually assessed for the greater of the 200 largest exposures or 75 percent of the value of the loan portfolio. Exposure to related parties - all related party transactions are audited. Valuation issues-the terms of transactions and their legal documentation were reviewed to prevent window-dressing of the accounts.

The audits showed nonperforming loans (NPLs) of the banks covered by the program ( 24 banks) were 25 percent at end-2001, much higher than the 7 percent published prevlousiy. The level of NPLs varies substantially from bank to bank. Out of the eight largest banks, two have less than 10 percent NPLs; three are between 10 and 20 percent, and three are above 20 percent. The range is from 2 to 56 percent.

Banks seem to have made sufficient provisions for NPLs, and to have been cautious in valuing collateral. On average, banks have put aside reserves equal to 40 percent of NPLs (as measured by principal value-interest accrued but not paid has been completely reversed from banks' income statements). Of the eight largest private banks, two have provisioned for more than 50 percent of outstanding NPLs, four between 30-50 percent and two for less than 30 percent. This may reflect differences in the amount of connected loans, as well as the quality of collateral. During the first quarter of 2001 , shareholder equity increased by roughly US $\$ 1.5$ billion, although only 40 percent of this came from an increase in paid-in capital.

The audits have also shown a dramatic drop in profitability between the third quarter (a total profit of US\$0.6 billion) and the fourth quarter of 2001 (a loss of US\$4.6 billion). More than half the total loss is related to one bank, but a further six of the eight largest banks also made substantial losses. The main reasons include increased provisioning and losses in the foreign exchange market.

As a result of the audits, the BRSA has assessed that banks had a capital shortfall of close to US\$1 billion, slightty more than indicated by the first and second audits. On June 13,2002 the BRSA announced that as of end2001 the capital shortfall in banks amounted to TL 1,326 trillion (a little less than US\$1 billion). This figure excludes the US $\$ 1.9$ billion capital shortfall in one deeply insolvent bank-Pamuk-which was intervened and taken over by BRSA on June 19, 2002. The figure also assumes that the government will honor guarantees it has given earlier to certain loans (and thus for which banks are not Iequired to provision). Excluding Pamuk, banks have already raised or committed to raise roughly US\$0.8 billion, with a considerable portion of this coming from a reduction in related party exposures.

Several factors suggest that the estimated shortfall of just under US\$1 billion is reasonable. First, private banks raised close to US $\$ 1.5$ billion in capital during the second half of 2001 . Second, the 19 weakest private banks in the system were taken out during 2000-01. Finally, the intraduction of inflation accounting reduced the amount of capital some banks had to raise. However, the BRSA will need to closely monitor developments, including changes in profitability and the evolution of asset quality, to ensure that the banking system remains adequately capitalized. 
including the need to underscore the protection afforded by the deposit guarantee scheme, as well as making liquidity available on a selective basis, and fully sterilized, if needed.

21. Building on the conduct of the audit and recapitalization exercise, the BRSA was continuing to take steps to enhance transparency and promote soundness of the banking system ( $\mid 10$ and 12-13). The BRSA would report on the exercise first to the Council of Ministers and subsequently to the public in a seminar, explaining how international standards were applied in determining capital needs. In June, the BRSA would also issue a regulation requiring full implementation of International Accounting Standards by end-2002. The SDIF was exploring the scope for establishing an Asset Management Company to assist in resolving bad assets held by the banks. Steps to improve the operating environment for banking and to promote money and foreign exchange markets had also started, although intermediation costs remained high.

22. Other banking reforms were also on track ( $\uparrow 11$ and 14). The operational restructuring of state-owned Ziraat and Halk banks was procecding as envisaged. With 581 branches closed as of May 20,2002, the authorities were confident that the end-June structural performance criterion on closing 800 branches would be met. The privatization of Vakif had been set back a few weeks, after potential investors requested that it too go through the same audits as private banks under the recapitalization exercise. The SDIF was also making progress in ensuring the transparency of its operations, including through completing an extemal audit of its accounts, and resolving the remaining intervened banks.

\section{The authorities have finally succeeded in introducing the Istanbul Approach to} expedite corporate debt restructuring ( $\ 15$ and Box 5), Initiation of this out-of-court framework for corporate debt restructuring had been delayed, in part owing to lobbying efforts by banks seeking regulatory forbearance on loan loss provisioning as part of the Istanbul Approach. However, the authorities had rightly resisted these efforts, noting that such forbearance would reduce rather than strengthen banks' incentives for corporate debt restructuring. With this issue resolved in early June, 24 banks - all eligible domestic public and private banks, except for two which are in merger talks with foreign partners-and 13 nonbank financial companies signed the framework agreement supporting the Istanbul Approach. However, effective operation of the Istanbul Approach remains a challenge. The willingness and capacity of banks and corporates to engage in substantial restructuring, rather than mere debt rescheduling, has yet to be tested. To address this concern, the World Bank has proposed supporting corporate workouts by providing loans to banks (guaranteed by the Turkish government) to be used to provide working capital to corporates whose debt is restructured. Furthermore, some legal and regulatory amendments have been put in place to facilitate workouts, including tax exemptions for debt write-offs.

24. The authorities recognized that reform of the legal framework for corporate insolvency and rehabilitation was needed to make a success of the Istanbul $\Lambda$ pproach, and out-of-court agreement on debt restructuring more generally ( $\$ 16)$. Under the existing Execution and Bankruptcy Act, judicial insolvency and court-supervised 


\section{Box 5. What is the Istanbul Approach?}

The Istanbul Approach is an out-of-court framework for the restructuring of corporate debt, in part drawing on methods used by the Asian crisis countries. This box explains the main features of this framework and the chatlenges for its successful implementation.

Although discussions were initiated last fall, the authorities have had to overcome many challenges before being able to introduce the new framework. The first step was to put in place the legal foundation for the Istanbul Approach, which was done on January 31,2002, with passage of the Law on Restructuring of Debts to the Financial Sector. The Law endorses the creation of a Financial Restructuring Program Framework Agreement among creditor institutions, subject to approval of its terms by the BRSA. The BRSA has subsequently been involved in the drafting of the Framework Agreement by the Turkish Banks' Association, adopted facilitating regulations, and encouraged creditor participation. The World Bank has also been involved in formulating the Istanbul Approach as part of the Bank's support of recovery of the Turkish corporate sector. The authorities have also requested a World Bank corporate sector rehabilitation loan to banks to provide working capital to corporates whose debt is restructured.

The aim of the Istanbul Approach is to facilitate a restructuring of debts of productive and viable corporates experiencing liquidity problems. The Framework Agreement also mentions two additional objectives: (i) "to ensure the orderliness, accuracy, and transparency of the balance sheets of the real and financial sector institutions"; and (ii) "to improve tax collection by ensuring the continuation of economic activities of firms that have capacity of creating value and by ensuring that related financial sector institutions have healthier balance sheets."

The Framework Agreement signed in early June 2002 establishes a detailed organizational structure to facilitate corporate debt restructuring. It includes four main elements: (i) a coordination secretariat to act as a nondecision making executive body to facilitate implementation of the Framework Agreement principles; (ii) a Board of Arbitrators, with members designated by the Turkish Banks Association to settle disputes among participating creditor institutions and to resolve deadlocks; (iii) a consortium of creditor institutions formed in each case to act as the principal decision making group by a binding super-majority vote generally of those representing 75 percent of outstanding credit (where a 55 percent vote is achieved, the decision can be referred to the Board of Arbitrators); and (iv) a lead bank - expected to be the creditor with the largest exposure to the corporate debtor-is appointed to conduct negotiations and monitor implementation.

The Istanbul Approach adopts a number of standard corporate workout principles. The Framework Agreement includes provisions for information disclosure, confidentiality, recognition of pre-existing creditor seniority, new money, and for a standstill on creditor enforcement upon the decision of the consortium of creditor institutions. There is also a 90-day period of negotiation between the creditors and the debtor, subject to extension up to a maximum of 180 days with majority creditor approval. Agreement between the creditors and the debtor is formalized in a binding financial restructuring contract.

Successful operation of the Istanbul Approach will face many challenges. Market-oriented discipline is required to guard against misuse of the Approach in supporting nonviable firms that should be liquidated. Regulatory vigilance is also required to maintain integrity of the collaborative framework among creditor institutions (and any related corporates). Furthermore, an effective corporate bankruptcy and creditor rights legal framework would also enhance success of the Istanbul Approach. In this regard, prompt reform of the Execution and Bankruptcy Law is needed, particularly to encourage debtors to come to the workout-negotiating table and to endorse workout agreements through "pre-packaged bankruptcies." 
rehabilitation proceedings are rarely used, in large part due to extensive delays in the resolution of cases and the exception of secured creditors from these proceedings. Around 90 percent of all bank credit is secured, principally by real estate mortgages. Such secured creditors typically use foreclosure proceedings rather than debt workouts to enforce their credit claims. However, foreclosure is itself fraught with inefficiency, the typical contested case lasting 2 to 3 years. The Turkish authorities have recognized the need for corporate insolvency law reform to support operation of the Istanbul Approach and more generally to foster efficient growth in the corporate and banking sectors. The authorities are now committed to passing comprehensive amendments to the Execution and Bankruptcy Act by end-January 2003, in line with the pending recommendations of the World Bank Report on Standards and Codes on Turkey's insolvency regime.

\section{E. Enhancing the Role of the Private Sector}

25. The authorities acknowledged the need to accelerate privatization ( $(20-21)$. They conceded that progress had been slow, but stressed that unfavorable market conditions had hampered efforts in this area. Against this difficult background, both sides agreed that further progress in privatization was needed, and that this would help foster a dynamic private sector in Turkey (Box 6). To this end, a set of actions and new indicative targets were agreed. As noted earlier, with the approval of a far-reaching corporatization plan for Türk Telekom, the adoption of a privatization plan is not possible until this fall, but early actions have been taken to make the new deadline feasible and the adoption of the privatization plan is now an end-November 2002 structural benchmark. Other important actions include the preparation of a privatization road map for \$EKER (sugar company) in May, the decisions to close or merge nonviable companies, and the planned reductions of the public share in TÜPRAS (oil refinery) and ERDEMIR (steel company) to below 50 percent. Finally, the new cumulative quarterly indicative targets on privatization proceeds-US\$700 million for the full year 2002-will facilitate monitoring privatization during future program reviews.

26. The authorities were also moving ahead with their plans to improve the business environment and enhance public sector transparency (122). The staff commended the authorities on their progress in improving the environment for both domestic and foreign investors. The submission to parliament of the new Law on Foreign Direct Investment, and the appointment of the Ministerial Steering Group and the supporting subcommittee for public sector reform (both structural benchmarks) were particularly welcome. The staff also noted that the local business community had high expectations for the inaugural meeting of the advisory Investor Council on July 18, and was pleased that preparations for the meeting were at an advanced stage. Both sides recognized that further reducing red tape, introducing a code of conduct for custom officials, and improving transparency in the use of public resources will also help strengthen the business climate in Turkey. 


\section{Box 6. Turkey's Privatization Experience}

A dynamic private sector has developed in Turkey since market reforms started in the early 1980s, but state ownership continues to dominate in several key sectors. From 1980 to 1999 , in the manufacturing sector the private sector share of production increased from 59 percent to 78 percent, the number of public enterprises fell from 400 to 300 , while the number of private enterprises increased from 8,300 to 11,600 , and the private sector share of employment increased from 64 percent to 88 percent. Nevertheless, majority state ownership remains the rule in several sectors, including in areas where the public sector has no obvious comparative advantage. Sectors as diverse as agricultural processing, telecoms, electricity generation and distribution, gas distribution, petroleum refining, steel manufacturing, mining, and transportation all remain government dominated.

Turkey's state economic enterprises (SEEs) have in many cases been a drain on the government budget, while delivering services at high prices and of inferior quality. As SEEs have been running large operating losses (giving rise to total annual financing requirements of about 2 percent of GNP and budget transfers of about 1 percent of GNP on average over the last decade), they have represented a major burden on the government budget. The losses were a result of overstaffing, high wages of public sector workers, low investment efficiency, and nontransparent operations. As an example, the cost of electricity in Turkey, at US\$0.07 per KWh, is higher than in any EU country. In short, the SEEs have become a hindrance to Turkey realizing its growth potential.

While the legal and instltutional framework has been in place for some time, privatization has lagged. The framework for privatization is laid out in Law No. 4046 from 1994, which defines general privatization rules and the institutional setup; separate laws exist for privatization of certain companies, including Türk Telekom and state banks. Two main bodies are in charge of privatization: (i) the High Privatization Council (HPC), composed of the Prime Minister, Deputy Prime Ministers, and selected line ministers, which makes decisions on which enterprises to privatize and also on the details of each sale; and (ii) the Privatization Administration, reporting directly to the Prime Minister, which executes the decisions of the HPC. Turkey's progress in privatization has been lagging well behind that of comparable countries, which has also been reflected in low FDI inflows. Total privatization receipts in the 1990 s amounted to some US\$4.5 billion (or US\$7 per capita annually). Likewise, FDI inflows in the 1990s were in the order of US $\$ 800$ million per yeat, or 0.4 percent of GNP, compared with a developing country average of 2 percent of GNP. Moreover, only about one third of the privatizations involved FDI. The factors behind this weak performance include macroeconomic instability, at times adverse market conditions, lack of political determination in following through with the necessary restructuring of SEEs, and shortcomings in the institutional setup, notably political interference in the privatization of individual companies.

Privatization of SEEs is central to the achievement of sustainable economic growth. An acceleration of privatization will help underpin the success of the economic program by: (i) demonstrating to markets that the government is committed to the necessary restructuring of the economy; (ii) improving efficiency in resource allocation and lowering input costs; and (iii) helping alleviate the ongoing budget costs associated with loss-making SEEs. Evidence also suggests that increased privatization generates additional FDI by improving foreign investors" perceptions about the business environment in the host country (see a forthcoming IMF Working Paper by Stefania Bazzoni and Laura Resmini, "Does Privatization Attract Foreign Direct Investment? The Case of the Southern Mediterranean Countries"). The program therefore includes an ambitious schedule for privatization of key infrastructure companies. 


\section{STAFF APPRAISAL}

27. The anthorities' strong policy performance has already yielded tangible economic gains under their 2002-04 program. Fiscal policy remains on course, and the CBT has adhered to its prudent monetary policy. On the structural front, banking and public sector reforms have been impressive. Although recent political uncertainties have caused a weakening in financial market indicators, these economic policy achievements have been rewarded by a stronger-than-anticipated balance of payments position, a sharp drop in inflation and inflation expectations, and the beginnings of an economic recovery.

28. Nevertheless, key vulnerabilities remain, calling for unwavering commitment to the program. The program remains exposed to regional developments. On the domestic side, political uncertainties continue to pose a risk, as highlighted by the events since early May. At the same time, a weak (although improving) financial system and high public debt allow policymakers little leeway, Given these vulnerabilities, full implementation of the program strategyXaimed at a sound budget position, prudent monetary policy under a float, a solid banking system, and fundamental structural reforms Xoffers the best chance of preventing future crises and creating sustained economic growth. The authorities should also use any favorable market opportunities to build up financing cushions to further increase the economy's robustness to disturbances. However, for these efforts to be fully successful, lessening market concerns about domestic political uncertainty will be critical.

\section{Continued strict adherence to the program's fiscal targets is key to strong}

program implementation. To help promote debt sustainability, the authorities have over the past two years delivered a large fiscal adjustment, taking measures when needed to correct emerging deviations. This fiscal adjustment is one of the main achievements of the program, and the continued maintenance of a strong fiscal position is critical to the program's success. In light of recent weaknesses in SEE fiscal performance, continued vigilance is needed to safeguard the fiscal targets. In this regard, the authorities' intention to correct pricing deviations in state economic enterprises, and their more general commitment to strengthen oversight of these entities, is welcome. The authorities' commitment to maintain a public sector primary surplus of 6.5 percent of GNP in 2003, and over the medium term, is also welcome.

30. Full implementation of the broader public sector reform agenda is needed to underpin these fiscal efforts. In particular, having completed the restructuring of indirect taxes, the government will now need to focus its efforts on reforming direct taxes. Also, after having identified existing redundant staff positions in SEEs, downsizing will need to follow. Fiscal management will also need to be improved, as noted in the staff's Fiscal Management Assessment. In this regard, measures being taken to overhaul the tax administration and procurement procedures are a good start. The exemption of newly registered funds from tax investigation is, however, a retrograde step that could weaken future tax compliance. Looking forward, it will be vital to embed many transparency, governance, and expenditure management reforms in the forthcoming revision to the budget systems law. 
31. Monetary policy should remain focused on achieving the inflation target. The rapid decline in inflation and in inflation expectations is one of the major achievements under the program. The staff commends the CBT for its determination and strict focus on its assigned task of bringing about price stability. The CBT's technical preparations for introducing fully-fledged formal inflation targeting are encouraging and should, together with continued progress in improving the health of the banking system and the maintenance of fiscal discipline, help ensure a successful transition later this year as planned. Meanwhile, the CBT should also continue its policy of gradually building up its foreign exchange reserves, as long as the underlying balance of payments position continues to strengthen.

\section{Further measures to improve the operation of money and foreign exchange}

markets need to be taken. The recent decision by the CBT to enhance the remuneration of reserves and the impending removal of some nuisance taxes on financial intermediation are welcome. As intermediation costs remain high, the authorities should take opportunity of the planned direct tax reform planned to reduce the tax distortions in the financial markets.

\section{The BRSA should continue its good work on restoring the banking system to} soundness. The BRSA's handling of the private bank audit and recapitalization exercise has been impressive, and in line with international best practice. In this regard, the BRSA's recent courageous decision to take over a deeply insolvent medium-size bank is particularly commendable. Looking ahead, the BRSA should remain vigilant in monitoring developments, continuing to stick to international best practice. With the audit stage of the exercise now completed, the recapitalization scheme needs to be brought to an early and successful conclusion. This will help ensure that the banking system is strengthened and credit restored in a lasting way. The increased transparency in SDIF operations and the SDIF's determination to resolve the banks remaining under its control are also welcome. While the operational restructuring of state banks (Ziraat and Halk) is making good progress, further delays should be avoided in the privatization of Vakif Bank. As a complement to these banking reforms, the adoption of the Istanbul Approach for corporate debt restructuring, as well as the planned improvements in the legal framework for bankruptcy, are welcome initiatives.

34. Privatization must be speeded up. State enterprises still account for a large share of Turkey's GNP. Their inefficiencies and lack of hard budget constraints add to inflation pressures and undermine Turkey's growth performance and fiscal position. To make a clear break with the past inefficiencies, the privatization of key companies needs to move forward. The adoption of indicative program targets for privatization proceeds as a way of assessing progress in this area is therefore welcome. While the delay in adopting a privatization plan for Türk Telekom is regrettable, the authorities' quick actions to implement an alternative strategy based on the advice of intemational consultants and the World Bank indicate satisfactory progress toward meeting this prior action.

35. Other structural reforms will also need to be pursued vigorously, to lay the basis for continued macroeconomic stabilization and sustained economic growth. Besides 
stable macroeconomic conditions, the revival of private investment will depend on progress under the plans to improve the business environment and ensure transparency in government operations. Recent initiatives in this area, notably the presentation to parliament of a new Foreign Direct Investment Law and the setting up of the requisite committees to oversee the implementation of the public reform plan, are welcome first steps.

36. In light of continued strong program implementation, the staff recommends the completion the second review. Strict implementation has already produced tangible economic gains, and the authorities are determined to stay the course. While recognizing that risks remain, the staff believes that the authorities' impressive track record and demonstrated commitment to strong program implementation bode well for the program's success, and recommends completion of the second review. 
Table 1. Turkey: Prior Actions and Benchmarks Relevant for the Second Review

$\begin{array}{ccc}\text { Action } & \text { LOI } & \text { Status as of } \\ \text { June 19, 2002 }\end{array}$

\section{Banking reform}

The BRSA to (i) complete the final interpretation of the evaluations by end-April and (ii) send letters to banks stipulating required actions on the besis of this interpretation by May 15

The external audit of the SDIF for 2001 will be completed by end-April 2002

\section{Public sector reform}

Parliament to amend the Public Procurement Law by end-May 2002, to (i) bring the real value of the thesholds toward those in line with international best practice, and (ii) extend the minimum time period for procurement applicable for cases below the thresholds

Enact the first phase of the tax reform plan by end-April 2002

\section{0,31}

(January) 
Table 2. Turkey: Indicators of Externa1 Vulnerability, 1999-2004 1/

(In percent, uniess otherwise noted)

\begin{tabular}{|c|c|c|c|c|c|c|}
\hline & & & & \multicolumn{3}{|c|}{ Projections } \\
\hline & 1999 & 2000 & 2001 & 2002 & 2003 & 2004 \\
\hline CPI intlation (end-year) & 68.8 & 39.0 & 68.5 & 35.0 & 20.0 & 120 \\
\hline Public sector borrowing tequirement (in percent of GNP) & 24.1 & 19.5 & 21.2 & 11.6 & 9.3 & 6.4 \\
\hline Net debt of the public seetor (in pencent of GNP) & 610 & 57.7 & 93.3 & 77.4 & 71.3 & 68.1 \\
\hline Export Yotume (percent change) & 0.7 & 9.5 & 14.7 & 4.6 & 6.6 & 6.7 \\
\hline Impart rolume (percent change) & -13.3 & 31.4 & -23.0 & 10.8 & 8.8 & 7.4 \\
\hline Current account balance (in percent of GNP) & -0.7 & -49 & 23 & $-\mathbf{l}+\mathbf{l}$ & -1.0 & -1.1 \\
\hline Capital account balance (in billions of USS) & 6.6 & 6.8 & -16.2 & -1.6 & 3.0 & 7.0 \\
\hline $\begin{array}{l}\text { Of which: } \\
\text { Foreign direct investment }\end{array}$ & 0.1 & 0.1 & 2.8 & 1.0 & 10 & 12 \\
\hline Fantign portfotio investment & 0.2 & -5.2 & -4.6 & -0.6 & -0.5 & 0.7 \\
\hline Gross official teserve (it billions of US\$) $y$ & 24.3 & 23.2 & 19.8 & 24.0 & 25.5 & 29.4 \\
\hline In months of inports of goods and NFS & $\$ .3$ & 4.0 & 4.4 & 4.9 & 4.7 & 5.0 \\
\hline In percent af broed money & 32.5 & 27.8 & 27.0 & 32.1 & 30.8 & 33.0 \\
\hline Gross total exterpal debt (in billions USS) & 103.1 & 119.6 & 117.5 & 123.1 & 1263 & 130.8 \\
\hline In percent of GNP & 55.1 & 59.4 & 80.2 & 66.7 & 64.8 & 62.6 \\
\hline In percent of exports of goods and NFS & 225.6 & 233.8 & 233.7 & 2449 & 226.4 & 218.1 \\
\hline Gross short-term extemal debt (in billious US\$) 3/ & 39.0 & 46.3 & 33.4 & 32.9 & 33.7 & 36.5 \\
\hline In percent of gross total external deth & 37.8 & 38.7 & 28.5 & 26.7 & 26.7 & 27.9 \\
\hline In percents of gross official reserves & 160.7 & 199.6 & 1689 & 137.4 & 132.2 & 124.4 \\
\hline Debt service $4 I$ & 34.1 & 370 & 43.2 & 40.7 & 41.4 & 375 \\
\hline REER appreciation (CPI based, period average) & 4.1 & 9.9 & -18.3 & $\ldots$ & $\ldots$ & $\ldots$ \\
\hline REER appreciation (CPI based, end of period) S/ & 5.6 & 13.7 & -21.3 & 18.4 & $\cdots$ & $\ldots$ \\
\hline Cappital adequacy ratio 6 & $\ldots$ & 17.3 & 16.8 & ... & $\ldots$ & ... \\
\hline State and SDIF banks & $\ldots$ & 7.9 & 27.6 & $\ldots$ & ... & +. \\
\hline Private beriks & $\ldots$ & 18.3 & 10.9 & ... & $\cdots$ & ... \\
\hline Foreign banks & $\cdots$ & 29.4 & 29.5 & $\ldots$ & $\ldots$ & $\ldots$ \\
\hline Nonperforming loass (in percent of total) $6 /$ & $\cdots$ & 9.2 & 12.9 & $\ldots$ & $\cdots$ & $\ldots$ \\
\hline Real brosd moncy (persentage change) 7 & 17.7 & 0.4 & 11.9 & -9.0 & 6.2 & 4.5 \\
\hline Real credit to the private seetor (percentage change) $7 /$ & -14.6 & 23.8 & -26.2 & $-11,0$ & 6.2 & 45 \\
\hline Barkss' net forcign asset position (in billians of LSS) & -2.9 & -5.8 & 2.4 & $\ldots$ & - & ... \\
\hline Spread on Turkish dollar Eumbends (in basis points) $\mathbb{N}$ & 550 & 443 & 718 & 846 & $\ldots$ & $\ldots$ \\
\hline
\end{tabular}

Sounces: Data provided by the Turkish anthories; and Fund staff estimates and projections.

1/ For 2002-05, program projections.

2/ As of end-May 2002. coserves stood at US\$22,4 billion (measured at program exchange pales).

3 B By residual maturity.

$4 /$ Interest plus medtum- and lang-tern debt repayments as percent of current aecount receipis (exchuting ofincial transfers).

5/ For 2002 as of May 2002.

6 As of September 2001 ; November 2001 for norperforning loans.

$7 /$ Deflated by the CPL.

8/ For 2002 as of June 18, 2000 . 
Table 3. Tukey: Selected Indicators, 1999-2004

\begin{tabular}{|c|c|c|c|c|c|c|}
\hline & 1999 & 2000 & 2001 & 2002 & 2003 & 2004 \\
\hline & \multicolumn{6}{|c|}{ (In percest) } \\
\hline \multicolumn{7}{|l|}{ Real sector } \\
\hline Real GNP growth rate & -6.1 & 6.3 & -9.4 & 3.0 & 5.0 & 5.0 \\
\hline GNP deflator & 55.8 & 50.9 & 57.8 & 49.4 & 26.0 & 133 \\
\hline Nominal CNP growth rate & 46.3 & 60.4 & 42.9 & 53.9 & 323 & 19.0 \\
\hline WPI (12-month, end-of-period) & 62.9 & 32.7 & 88.6 & 31.0 & 16.2 & 12.0 \\
\hline CPI (12-month, end-of periad) & 68.8 & 39.0 & 68.5 & 35.0 & 20.0 & $\$ 20$ \\
\hline Average nominal treasury bill interest rate & 106.2 & 38.0 & 99.1 & 63.1 & 46.0 & 38.1 \\
\hline \multirow[t]{2}{*}{ Averge ex-ante teal interest rate $1 /$} & 32.0 & -9.5 & 32.8 & 27.3 & 27.5 & 20.5 \\
\hline & \multicolumn{6}{|c|}{ (In percent of GNP) } \\
\hline \multicolumn{7}{|l|}{ Centraj government budget } \\
\hline Primary balance 2 & 1.5 & 4.3 & 4.6 & 5.3 & 5.6 & 5.6 \\
\hline Net interest payments 3 & 13.1 & 15.8 & 24.3 & 18.3 & 17.0 & $\ldots$ \\
\hline Overall balance & .11 .6 & -11.5 & -19.7 & -13.0 & -11.3 & $\cdots$ \\
\hline \multicolumn{7}{|l|}{ Consolidated pnbile sector } \\
\hline Prinary balapce & -2.0 & 2.4 & 5.9 & 6.5 & 6.5 & 6.5 \\
\hline Net interest payments 4 / & 22.1 & 219 & 27.1 & 18.1 & 15.8 & 12.9 \\
\hline PSBR (including CBT ptofits) & 24.1 & 19.5 & 21.2 & 11.6 & 9.3 & 6.4 \\
\hline Operational balance & -124 & -6.8 & -5.0 & -3.0 & -4.3 & -3.4 \\
\hline Net debt of public sector & 61.0 & 57.7 & 93.4 & $\pi .4$ & 71.3 & 68.1 \\
\hline Ner external & 20.1 & 18.5 & 37.1 & 32.4 & 27.2 & 25.2 \\
\hline Net domestic & 40.9 & 39.2 & 56.3 & 45.0 & 44.2 & 43.0 \\
\hline Net debt of public sactor (in percent of cenvered GNP) 5 ) & 48.6 & 51.5 & 75.7 & 67.0 & 65.3 & $\cdots$ \\
\hline \multicolumn{7}{|l|}{ External sector } \\
\hline Curreat account balance & -0.7 & -4.9 & 2.3 & -1.1 & -1.0 & -1.1 \\
\hline Gross external debt & $\mathbf{5 5 . 1}$ & 59.4 & 80.2 & 66.7 & 64.8 & 62.6 \\
\hline Net extemal debt & 33.7 & 39.2 & 54.5 & 44.6 & 43.0 & 40.3 \\
\hline Shart-tern extemal debt (by remaining maturiry) & 20.8 & 23,0 & 22.8 & 17.8 & 17.3 & 17.5 \\
\hline \multicolumn{7}{|l|}{ Monetary aquegates } \\
\hline Seignorage d & 3.2 & 1.8 & 1.1 & 1.1 & 0.7 & $\ldots$ \\
\hline \multirow[t]{2}{*}{ Nominal growth of M2Y broad miney (in percent) } & 98.7 & 39.6 & 88.5 & 22.9 & 27.4 & 17.1 \\
\hline & \multicolumn{6}{|c|}{ (In billions of U.S. dollars, unless otherwise indicated) } \\
\hline Pivatization proceeds & 0.1 & 3.3 & 2.8 & 0.7 & 25 & $\ldots$ \\
\hline Net extemal finarcing of tentral goverumeat & 1.4 & 4.1 & -20 & .0 .2 & -1.1 & $\cdots$ \\
\hline Amortivation & 6.0 & 6.2 & 7.8 & 6.7 & 8.3 & $\cdots$ \\
\hline Gross borrowing & 7.4 & 10.3 & 5.8 & 6.5 & 7,2 & ... \\
\hline Of which: Eurboond issues & 5.0 & 7.5 & 2.2 & 3.0 & 4.5 & $\ldots$ \\
\hline GNP & 187.4 & 201.3 & 146.5 & $\ldots$ & $\ldots$ & $\ldots$ \\
\hline GNP (in quadrilions of Tukist lira) & 78.3 & 125.6 & 179.5 & 2762 & 365.6 & 435.1 \\
\hline
\end{tabular}

Soureses Data provided by Turkish authorities; and Fund staff estimates.

$1 /$ Average of monthly nominal interest rate divided by 12-inonth ahead CPI inflation. With average maturity of dewly isaned debt less than one year, and with FRNis paying quantedy coupons, this measure oversiates the offective real incerest rate when inflation is declining.

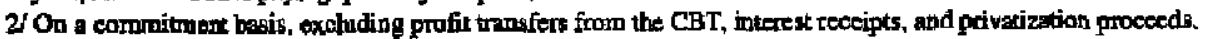

$3 /$ Interest payments minus interest receipts plus profit transfers from the central bank

4/ Interest payments minus interest receipts plus CBT profits before transfers to the govermment.

5/ Defined as the sun of quarterly GNP in the last two quarters of the year and in the first two quatets of the following year.

6 Change in base money in peroent of GNP, whoo base money is defined as enrency issued plus neserve requirements. 
Table 4. Turkey: Balance of Payments, 1998-2005

(In billions of U.S. dollars)

\begin{tabular}{|c|c|c|c|c|c|c|c|c|}
\hline & 1998 & 1999 & 2000 & 2001 & 2002 & 2003 & 2004 & 2005 \\
\hline Ourent account balance & 2.0 & .1 .4 & -9.8 & 3.3 & -2.0 & -2.0 & .2 .4 & .1 .9 \\
\hline Trade bulance & -14.2 & -10.4 & -22.4 & -4.8 & -73 & -8.6 & -9.4 & $-10,4$ \\
\hline Exports (fob) & 31.2 & 29.3 & 31.7 & 35.1 & 36.6 & 39.6 & 42.8 & 46.3 \\
\hline \multicolumn{9}{|l|}{ Of which: } \\
\hline Exports (fob) in trade rehums & 27.0 & 26.6 & 27.8 & 31.2 & 32.5 & 35.2 & 38.0 & 41.1 \\
\hline Shuttle trade & 3.7 & 2.3 & 2.9 & 3.0 & 3.2 & 3.4 & 3.7 & 4.0 \\
\hline Imports (fob) & -45.4 & -39.8 & .54 .1 & -39.9 & -43.8 & -48.2 & -52.2 & .56 .7 \\
\hline \multicolumn{9}{|l|}{ Of which: } \\
\hline Imports (cif) & -45.9 & -40.7 & .54 .5 & -40.5 & -44.4 & -48.8 & -52.8 & .57 .0 \\
\hline Energy imports (cif) & -4.5 & -5.3 & -9.5 & -8.3 & -8.2 & -8.3 & -8.3 & -8.7 \\
\hline Servios (net) & 10.5 & 3.9 & 7.4 & 4.1 & 1.0 & 2.0 & 1.9 & 3.0 \\
\hline Services (credit) & 25.8 & 18.7 & 22.3 & 179 & 15.7 & 18.9 & 20.7 & 22.7 \\
\hline \multicolumn{9}{|l|}{ Of which: } \\
\hline Interest & 2.5 & 2.4 & 2.8 & 2.8 & 2.0 & 2.7 & 35 & 45 \\
\hline Tourism receipts & 72 & 5.2 & 7.6 & 8.1 & 6.5 & 8.0 & 8.5 & 8.9 \\
\hline Other receipts 1 i & 10.5 & 7.1 & 7.9 & 3.6 & 3.5 & 4.2 & 4.5 & 49 \\
\hline Services (debit) & -15.3 & -14.8 & +15.0 & -13.8 & -14.7 & -16.8 & .18 .8 & -19.7 \\
\hline \multicolumn{9}{|l|}{ Ofwhich: } \\
\hline Interest & 4.8 & -5.5 & -6.3 & -7.1 & -7.0 & -8.4 & -9.5 & -9.6 \\
\hline Private transfers (net) & 5.6 & 4.8 & 5.0 & 3.8 & 3.9 & 4.4 & 4.9 & 53 \\
\hline \multicolumn{9}{|l|}{ Of which: } \\
\hline Workers remittances & 5.4 & 4.5 & 4.6 & 2.8 & 3.1 & 3.6 & 4.0 & 4.4 \\
\hline Official transfers (net) & 0.2 & 0.4 & 0.2 & 0.2 & 0.3 & 0.2 & 0.2 & 0.3 \\
\hline Capital account balance & 0.4 & 4.7 & 9.4 & -13.9 & -0.6 & 3.0 & 7.0 & 8.2 \\
\hline (incluting enors and omissions) & -15 & 6.6 & 6.8 & -16.2 & -1.6 & 3.0 & 7.0 & 8.2 \\
\hline Dired investuent 2 & 0.6 & 0.1 & 0.1 & 2.B & 1.0 & 1.0 & 1.2 & 1.5 \\
\hline Portfolio investment in secaurities 2 & -6.1 & 0.2 & -5.2 & -4.6 & -0.6 & -0.5 & 0.7 & 0.8 \\
\hline Publin secior (central \& local governments \& EBFs) & -1.9 & 1.2 & 6.2 & -1.9 & 1.3 & -0.5 & 1.1 & 1.5 \\
\hline Bonds (net) & -0.3 & 3.1 & 6.1 & 0.1 & 0.9 & 0.6 & 1.7 & 19 \\
\hline Euroband drawings & 2.7 & 5.0 & 7.5 & 2.1 & 3.0 & 4.5 & 4.7 & 5.0 \\
\hline Euroborit repayments & .3 .0 & -1.9 & -1.4 & -2.0 & -2.1 & -3.9 & -3.1 & -3.1 \\
\hline Loans (net) & -1.7 & -1.9 & 0.1 & .2 .0 & 0.4 & .1 .1 & -0.6 & -0.3 \\
\hline Loan disbursements & 12 & 1.0 & 3.7 & 2.6 & 3.8 & 2.7 & 2.8 & 2.9 \\
\hline Loan repayments & -2.8 & -2.9 & .3 .6 & -4.6 & -3.4 & -3.8 & -3.4 & $-3,2$ \\
\hline Central Bank of Turkey, Dresdner (net) & 0.7 & -0.2 & 0.7 & 0.8 & 0.3 & 0.7 & 0.7 & 0.8 \\
\hline Domestic maney banks (net) & 1.9 & 0.5 & 2.1 & -9.1 & -2.5 & 0.9 & 1.6 & 1.4 \\
\hline Domestic money banks (FX deposits abmad, -: acourinlation) & -0.8 & +1.8 & -1.9 & t.o & 1.5 & 0.0 & 0.0 & -0.1 \\
\hline Dornestic money banks (other, net) & 2.7 & 2.4 & 4.0 & -10.1 & -40 & 0.9 & 1.6 & 1.5 \\
\hline Domestic soney banks (mudium and long term, net) & 0.5 & 02 & .0 .2 & -1.0 & -1.1 & 0.3 & 0.8 & 0.5 \\
\hline Domestic money banks (shorc term, nea) & 2.2 & 22 & 4.2 & -9.1 & -2.9 & 0,6 & 0.8 & 1.0 \\
\hline Intertark eredit lines from fopeign commersisl banks & 0.1 & 2.1 & 4.7 & -5.9 & -2.0 & 0.5 & 0.6 & 0.7 \\
\hline Other private sector (net) & 5.3 & 2.8 & 5.6 & .1 .8 & -0.2 & 1.4 & 1.6 & 2.2 \\
\hline Other paivate sectnr (medium and long term, net) & 4.2 & 23 & 4.9 & 0.3 & -0.6 & 0.0 & 0.4 & 0.9 \\
\hline Other private sector (shout term, net) & 1.1 & 0.5 & 0.6 & -2.1 & 0.4 & 1.4 & 1.2 & 13 \\
\hline Errors and omiassions & -2.0 & 1.9 & -2.7 & -2.4 & -1.0 & 0.0 & 0.0 & 0.0 \\
\hline Overall balance & 0.4 & 5.2 & -3.1 & -12.9 & -3.7 & 1.0 & 4.6 & 6.3 \\
\hline Overill finatleing & -0.4 & -5.2 & 3.1 & 129 & 3.7 & -1.0 & -4.6 & -6.3 \\
\hline Change in net intemational reserves (+ denotes declins) & -0.4 & -5.2 & 3.1 & 12.9 & 3.7 & -1.0 & 4.6 & -6.3 \\
\hline Chonge in gross official reserves (+ denotes decline) & $-0,2$ & -59 & -02 & 2.7 & -4.2 & -1.5 & -3.9 & 1.4 \\
\hline Change in reserve lisbilities (IMP) & -0.2 & 0.7 & 3.3 & 10.2 & 7.9 & 0.5 & -0.7 & -7.8 \\
\hline Purehases & 0.0 & 0.8 & 3.4 & 11.4 & 14.0 & 1.0 & 1.0 & 00 \\
\hline Repurchtases & -0.2 & -0.1 & -0.1 & -1.1 & -6.1 & -0.5 & -1.7 & -7.8 \\
\hline
\end{tabular}


Table 4 (conchuded). Turkey: Balance of Payments, 1998-2005

(In billions of U.S. dojlars)

\begin{tabular}{|c|c|c|c|c|c|c|c|c|}
\hline & 1998 & 1999 & 2000 & 2001 & 2002 & 2003 & 2004 & 2005 \\
\hline Memorantum items: & & & & & & & & \\
\hline \multicolumn{9}{|l|}{ Trade in goods and services } \\
\hline \multicolumn{9}{|l|}{ As percent of GNP } \\
\hline Current account balance, inchuding shutte tradte & 1.0 & -0.7 & -4.9 & 2.3 & -1.1 & -1.0 & -1.1 & -0.8 \\
\hline Trade account balanse inchuding shuttle trade & -6.9 & -5.6 & -11.1 & -3.3 & -3.9 & -4.4 & -4.5 & 4.6 \\
\hline Exports of goods and nonfactor services & 26.5 & 24.4 & 25.4 & 34.3 & 27.2 & 28.6 & 28.7 & 28.6 \\
\hline Imports of goods and nonfactor services & 27.2 & 26.2 & 31.2 & 31.8 & 27.9 & 29.1 & 29.4 & 29.6 \\
\hline \multicolumn{9}{|l|}{ Pexcent change } \\
\hline Value growth in exports of gonds (incluting stultte trade) & -4.4 & -6.1 & 8.0 & 10.9 & 4.2 & 8.3 & 8.1 & 8.1 \\
\hline Vahe growth in exports of goods (excluding shaltle trade) & 2.7 & -1.7 & 6.1 & 11.6 & 4.2 & 8.3 & 8.1 & 8.1 \\
\hline Vahe growth in imports of geods & -5.3 & -12.5 & 36.0 & -26.3 & 99 & 10.0 & 8.2 & 8.7 \\
\hline Volume growth in exports of goods & 5.8 & 0.7 & 9.5 & 14.7 & 4.6 & 6.6 & 6.7 & 6.7 \\
\hline Volume growth in imports of goods & 0.6 & -13.3 & 31.4 & -23.0 & 10.8 & 8.8 & 7.4 & 6.7 \\
\hline Terms of trade & 3.3 & -42 & -6.4 & 1.4 & 0.6 & 0.6 & 0.6 & 0.1 \\
\hline \multicolumn{9}{|l|}{ Reserve and debt indicators } \\
\hline \multicolumn{9}{|l|}{ Gross foreign reserves (Central Bank of Turkey) } \\
\hline In billions of U.S. dollars & 20.9 & 24.3 & 23.2 & 19.8 & 24.0 & 25.5 & 29.4 & 27.9 \\
\hline Months of goods \& NFS inports & 4.1 & 5.3 & 4.0 & 4.4 & 4.9 & 4.7 & 5.0 & 4.4 \\
\hline \multicolumn{9}{|l|}{ Extecual debt (end-of-period) } \\
\hline In billions of U.S. dollars & 97.2 & 103.1 & 119.6 & 117.5 & 123.1 & 1263 & $130 . \mathrm{B}$ & 129.2 \\
\hline In percent of GNP & 47.2 & 55,1 & 59.4 & 80.2 & 66.7 & 64.8 & 62.6 & 57,3 \\
\hline In percent of exports of goods \& NFS & 178.3 & 225.6 & 233.8 & 233.7 & 244.9 & 226.4 & 218.1 & 200.4 \\
\hline \multicolumn{9}{|l|}{ Net external debt (end-of-period) $3 /$} \\
\hline In bilhions of U.S. dollars & 63.1 & 63.2 & 78.9 & 79.8 & 82.4 & 83.8 & 84.3 & 83.9 \\
\hline In percent of GNP & 30.6 & 33.7 & 39.2 & 54.5 & 44.6 & 43.0 & 40.3 & 37.2 \\
\hline \multicolumn{9}{|l|}{ Short-tem daht (end-of-period) } \\
\hline In billions of U.S. dollers & 21.2 & 23.5 & 28.9 & 17.6 & 15.4 & 17.6 & 19.8 & 22.4 \\
\hline Ratio to farrign raserves & 101.6 & 96.7 & 124.6 & 89.0 & 64.1 & 68.9 & 67.5 & 80.2 \\
\hline \multicolumn{9}{|l|}{ Short-tern deht plus MLT tepaymoents } \\
\hline In billing of U.S. doillars & 33.8 & 39.0 & 46.3 & 33.4 & 32.9 & 33.7 & 36.5 & 39.2 \\
\hline Ratio to foreign reserves & 161.9 & 160.7 & 199.6 & 1689 & 137.4 & 132.2 & 124.4 & 140.4 \\
\hline Debl service ratio 4 & 26.0 & 34.1 & 37.0 & 43.2 & 40.7 & 41.4 & 37.5 & 35.3 \\
\hline
\end{tabular}

Sources: Data provided by the Turkish anthorities; and Fund staff extimates and projections.

1/ The decline in other receipts between 1998 and 2000 partly raflects a methodological change in the conpilation of this item.

2/ Inchuding privatization receipts.

3/ Nonbank extemal debt less the NFA of the banking system.

4 Interest plus mediun- and long-teom dehe repayments as percent of current account receipts (excluding official transfiers). 
Table 5. Turkey: Composition of Public Sector Net Debt

\begin{tabular}{|c|c|c|c|c|}
\hline & 2000 & 2001 & 2000 & 2001 \\
\hline & \multicolumn{2}{|c|}{ In quadrillions of $\mathrm{TL}$} & \multicolumn{2}{|c|}{ In percent of GNP } \\
\hline Net debt of the public sector & 72.5 & 167.7 & 57.7 & 93.4 \\
\hline Central Government & 75.3 & 181.2 & 60.0 & 101.0 \\
\hline External (excluding IMF) & 26.6 & 56.0 & 21.1 & 31.2 \\
\hline Domestic & 51.5 & 130.1 & 41.0 & 72.5 \\
\hline Cash debt $1 /$ & 29.5 & 60.4 & 23.4 & 33.7 \\
\hline Of which: onlending by CBT & 0.0 & 13.9 & 0.0 & 7.8 \\
\hline Noncash debt $2 /$ & 22.0 & 63.9 & 17.5 & 35.6 \\
\hline Contingency $3 /$ & 0.0 & 5.5 & 0.0 & 3.1 \\
\hline Deposits 4 ! & 2.7 & 4.9 & 2.2 & 2.7 \\
\hline Rest of the public sector & 8.1 & 7.6 & 6.5 & 4.2 \\
\hline External & 4.3 & 8.2 & 3.4 & 4.6 \\
\hline Domestic & 3.9 & -0.6 & 3.1 & -0.3 \\
\hline Of which : assets of the UIF & 0.4 & 2.3 & 0.3 & 1.3 \\
\hline Central bank net assets & 11.0 & 21.1 & 8.7 & 11.8 \\
\hline Net foreign assets & 7.6 & -2.4 & 6.0 & -1.3 \\
\hline Net claims on the central government & 0.4 & 30.1 & 0.3 & 16.8 \\
\hline Other net domestic assets 5/ & 3.0 & -6.6 & 2.4 & -3.7 \\
\hline \multicolumn{5}{|l|}{ Memorandum icems: } \\
\hline FX-indexed net debt & 26.6 & 107.9 & 21.2 & 60.1 \\
\hline Lira-denominated net debt & 45.9 & 59.5 & 36.5 & 33,2 \\
\hline
\end{tabular}

1/ Debt issued for bodget financing. The end-2001 figure vahes the fx-indexed bonds issued as part of the June 2001 debt swap at the end-2001 exchange rate, resulting in a higher figure than reported by Treasury which values these bonds at the lower issue.

$2 /$ Including debt issued for bank recapitalization. The end-2000 total includes unsecuritized dutylosses of stare banks.

3/ Contingency for possible additional public sector support for bank recapitalization.

4/ Central government deposits at the CBT, and in commercial banks as reported in the monetary survey.

5/ Defined as net claims on banks minus free TL and FX reserves, minus liabilities (mostly deposits) to ather public sector instibutions. 
Table 6. Turkey: Public Sector Borrowing and Net Debt in 2002

\begin{tabular}{lrr}
\hline & $\begin{array}{r}\text { In quadrilions } \\
\text { of Turkist lira }\end{array}$ & $\begin{array}{r}\text { In percent } \\
\text { of GNP }\end{array}$ \\
\hline Stocks & & \\
Net public debr (end-2001) & 167.5 & 93.3 \\
Ner public debt (end-2002) & 213.8 & 77.4 \\
Flows & & \\
Change in net debt & & 16.8 \\
New borrowing & 46.4 & 9.6 \\
Valuation changes & 26.5 & 8.6 \\
minus change in CBT assets & 23.9 & 1.4 \\
Public sector borrowing requirement & 4.0 & 11.5 \\
New borrowing & & 9.6 \\
Privatization & 31.7 & 0.4 \\
Change in reserve money & 26.5 & 1.7 \\
Other $1 /$ & 1.2 & -0.2 \\
& 4.6 & \\
GNP 2001 & -0.6 & $\ldots$ \\
GNP 2002 & & $\ldots$ \\
& & \\
\hline
\end{tabular}

1/ Includes differences in cash and accrual accounting between the CBT and the rest of the public sector. 
Table 7. Turkey: Medium-Tern Public Debt Dynamics, 2001-06

(In percent of GNP)

\begin{tabular}{|c|c|c|c|c|c|c|}
\hline & 2001 & 2002 & 2003 & 2004 & 2005 & 2006 \\
\hline & \multicolumn{6}{|c|}{ (In percent of GNP) } \\
\hline Primary balance & 5.9 & 6.5 & 6.5 & 6.5 & 6.5 & 6.3 \\
\hline Interest & 27.1 & 18.1 & 15.8 & 12.9 & 12.1 & 10.8 \\
\hline Overall balance & -21.2 & -11.6 & -9.3 & -6.4 & -5.6 & -4.5 \\
\hline Operationai balance $1 /$ & -5.0 & -3.0 & -4.3 & -3.4 & -3.2 & -2.9 \\
\hline Privatization & 0.8 & 0.4 & 0.9 & 0.5 & 0.5 & 0.5 \\
\hline Change in reserve money & 1.5 & 1.7 & 1.3 & 0.8 & 0.7 & 0.5 \\
\hline Net debt & 93.3 & 77.4 & 71.3 & 68.1 & 65.4 & 63.0 \\
\hline External debt & 37.1 & 32.4 & 27.2 & 25.2 & 24.7 & 24.3 \\
\hline \multirow[t]{2}{*}{ Domestic debt } & 56.2 & 45.0 & 44.2 & 43.0 & 40.8 & 38.8 \\
\hline & \multicolumn{6}{|c|}{ (In percent) } \\
\hline Real GNP growth & $-9,4$ & 3.0 & 5.0 & 5.0 & 5.0 & 5.0 \\
\hline Inflation & 68.5 & 35.0 & 20.0 & 12.0 & 8.0 & 5.0 \\
\hline Share of FX-tinked debt in total & 64.5 & 62.9 & 56.4 & 54.5 & 51.9 & 48.9 \\
\hline Nominal interest rate on TL debt & 99.1 & 63.1 & 46.0 & 38.1 & 29.8 & 25.7 \\
\hline Real interest rate on TL debt $2 /$ & 32.8 & 27.3 & 27.5 & 20.5 & 18.0 & 18.0 \\
\hline
\end{tabular}

1/ Adjusts for the impact of inflation on the debt stock. Since interest payments are measured on a cash basis, the operational balance will adjust to changes in interest rates and the underlying fiscal position with a lag.

2/ Ex ante real interest rate using 12 -month ahead program inflation. 
Table 8. Turkey: Indicators of Fund Credit, 2000-06

\begin{tabular}{|c|c|c|c|c|c|c|c|}
\hline & 2000 & 2001 & 2002 & 2003 & 2004 & 2005 & 2006 \\
\hline \multicolumn{8}{|l|}{ Outstanding Fund credit (end of period) } \\
\hline In billions of SDRs. & 3.2 & 11.2 & 17.5 & 17.9 & 17.3 & 11.2 & 3.6 \\
\hline In percent of quota & 333 & 1,165 & 1,817 & 1.859 & 1,798 & 1,157 & 375 \\
\hline In pencent of exports of goods \& NFS & 8 & 28 & 44 & 40 & 36 & 22 & 7 \\
\hline In percent of public sector external debt & 7 & 20 & 27 & 27 & 26 & 18 & 6 \\
\hline In percent of overall external debt & 3 & 12 & 18 & 18 & 17 & 11 & 4 \\
\hline In percent of foreign reserves & 18 & 72 & 91 & 88 & 74 & 50 & 18 \\
\hline \multicolumn{8}{|l|}{ Debt service due to the Fund } \\
\hline In billions of SDRs & 0.1 & 1.2 & 6.0 & 1.3 & 1.9 & 6.3 & 7.6 \\
\hline In percent of quota & 13 & 130 & 627 & 133 & 195 & 655 & 784 \\
\hline In percent of exports of goods NFS & 0 & 3 & 15 & 3 & 4 & 12 & 14 \\
\hline In percent of public sector external debt service & 0 & 4 & 28 & 6 & 9 & 29 & 33 \\
\hline In percent of overall external debt service & 1 & 6 & 32 & 6 & 9 & 27 & 31 \\
\hline In percent of foreign reserves & 1 & 8 & 33 & 7 & 8 & 29 & 39 \\
\hline
\end{tabular}


Table 9. Turkey: External Financing Requirements and Sources, 1998-2006

(In billions of U.S. dollars)

\begin{tabular}{|c|c|c|c|c|c|c|c|c|c|}
\hline & 1998 & 1959 & 2000 & 2001 & 2000 & 2000 & 2004 & 2005 & 2006 \\
\hline Gross finsancing requirements & 27.6 & 35.5 & 49.1 & 43.2 & 35.8 & 35.1 & 36.3 & 38.7 & 41.5 \\
\hline Cument account deficit (excluding official transfers) & -1.8 & 1.7 & 10.1 & -3.1 & 2.4 & 2.2 & 2.6 & 22 & 2.3 \\
\hline $\begin{array}{l}\text { Anprtization on debt securities } \\
\text { Of which: }\end{array}$ & $\mathbf{3 . 3}$ & 2.0 & 1.7 & 2.1 & 2.5 & 4.1 & 3.1 & 3.6 & 3.4 \\
\hline Public sector & 3.0 & 1.9 & 1.4 & 20 & $2.1^{\circ}$ & 3.9 & 3.1 & 3.1 & 32 \\
\hline Deposit money banks & 0.3 & 0.1 & 0.4 & 0.0 & 0.4 & 0.2 & 0.0 & 0.4 & 0.1 \\
\hline $\begin{array}{l}\text { Medimm- and long-term debt amortization } \\
\text { Of which: }\end{array}$ & 8.2 & 10.6 & 13.8 & 15.3 & 13.3 & 13.5 & 13.1 & 13.1 & 13.4 \\
\hline Public sector $1 /$ & 2.8 & 29 & 3.6 & 4.6 & 3.4 & 3.8 & 3.4 & 3.2 & 3.0 \\
\hline Privale sector & 3.0 & $\$ .2$ & 7.9 & 8.9 & 8.6 & 8.8 & 8.8 & 8.8 & 9.0 \\
\hline Deposit money banks & 2.3 & 2.4 & 2.3 & 1.9 & 1.4 & 1.0 & 1.0 & 1.2 & 1.4 \\
\hline Short-term debt amortization & 18.0 & 21.2 & 23.5 & 28.9 & 17.6 & 15.4 & 17.6 & 19.8 & 22.4 \\
\hline Publie sector $1 /$ & 0.9 & 0.9 & 0.7 & 1.7 & 0.8 & 0.8 & 0.9 & 0.9 & 1.0 \\
\hline Private sector & 8.6 & 9.2 & 9.6 & 10.4 & 8.3 & 8.6 & 10.0 & 11.2 & 12.5 \\
\hline Deposit money banks & 8.5 & 11.2 & 13.2 & 16.9 & 8.5 & 5.9 & 6.7 & 7.7 & 8.9 \\
\hline Aveilable finmeing & 27.6 & 35.5 & 49.1 & 43.2 & 35.8 & 35.1 & 36.3 & 38.7 & 41.5 \\
\hline Fortign duect idvestroent (net) & 0.6 & 0.1 & 0.1 & 2.8 & 1.0 & 1.0 & 1.2 & 1.5 & 1.9 \\
\hline Pottfolio flows & -3.4 & 5.4 & 28 & -2.5 & 2.5 & 4.2 & 5.6 & 6.1 & 6.2 \\
\hline Public sector & 2.7 & 5.0 & 7.5 & 2.1 & 3.0 & 4.5 & 4.7 & 5.0 & 5.0 \\
\hline Deposit money banks & 0.0 & 02 & 0.5 & 0.0 & 0.0 & 0.2 & 0.2 & 0.3 & a.3 \\
\hline Private sector (net) & -6.1 & 0.2 & -5.2 & -4.6 & -0.6 & 0.5 & 0.7 & 0.8 & a.9 \\
\hline $\begin{array}{l}\text { Mediutn- and long-tern debt financing } \\
\text { Of which: }\end{array}$ & 12.2 & 10.9 & 19.1 & 13.2 & 12.8 & 13.3 & 14.2 & 15.0 & 15.8 \\
\hline Public aector $1 /$ & 1.8 & 0.9 & 4.4 & 3.2 & 4.1 & 3.3 & 3.4 & 3.6 & 3.7 \\
\hline Privale sector & 7.2 & 7.5 & 12,8 & 9.2 & 8.0 & 8.8 & 9.2 & 9.6 & 10.1 \\
\hline Deposit money banks & 3.1 & 2.6 & 1.9 & 0.9 & 0.7 & 1.3 & 1.6 & 1.8 & 2.0 \\
\hline Short-term debt financing & 21.6 & 24.2 & 283 & 18.5 & 15.4 & 17.6 & 19.8 & 22.4 & 24.9 \\
\hline Official transfers & 0.2 & 0.4 & 0.2 & 0.2 & 0.3 & 0.2 & 0.2 & 0.3 & 0.3 \\
\hline Other $2 t$ & -3.0 & -0.3 & -4.5 & -2.1 & 0.2 & -0.2 & -0.2 & -0.3 & -0.5 \\
\hline Accumnlation of reserves net of DFF & -0.4 & -5.2 & 3.1 & 12.9 & 3.7 & -1.0 & -4.6 & -6.3 & -7.0 \\
\hline Accumulation of gross reserves & -0.2 & -5.9 & -0.2 & 2.7 & -4.2 & -1.5 & -3.9 & 1.4 & 2.5 \\
\hline IMF (net)/exceptional CBT financing & -0.2 & 0.7 & 3.3 & 10.2 & 7.9 & 0.5 & -0.7 & -7.8 & -9.5 \\
\hline Purchases & a0 & 0.8 & 3.4 & 11.4 & 14.0 & 1.0 & 1.0 & 0.0 & 0.0 \\
\hline Repunchases & 0.2 & 0.1 & 0.1 & 1.1 & 6.1 & 0.5 & 1.7 & 7.8 & 9.5 \\
\hline
\end{tabular}

1/ General government and Central Bank of Turtey.

2/ Errors and omissions. 


$$
-46-
$$

Table 10. Turkey: Public Sector Primary Balances, 2000-02

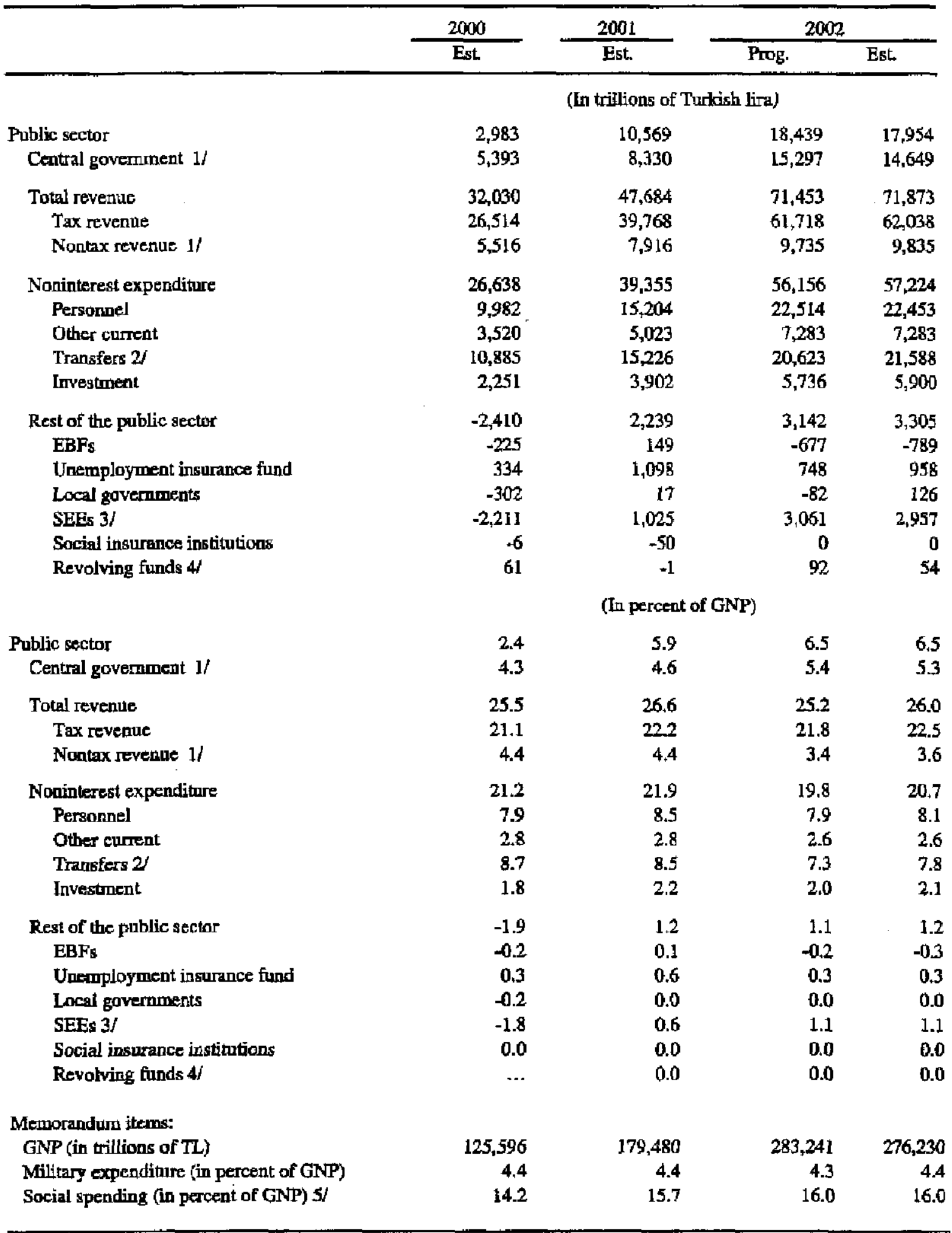

Sources: Turkish authorities; and Fund staff estimates.

1/ Excluding privatization proceeds, transfers from the CBT, and interest receipts.

2/ Excluding recapitalization of state banks.

3/ Excluding severance payments for retirses amounting to TL 201 trillion (0.1 percent of GNP).

4/ Added to the public sector balance for 2002. Not included in the 2001 primary surplus calculation.

5/ World Bank definition, including educstion, health and social security. 
Tabile 11. Turtey: Monetary Aggregates, 1999-2002

(In quadrillions of Turkish lia)

\begin{tabular}{|c|c|c|c|c|c|c|}
\hline & \multirow{2}{*}{$\begin{array}{l}1999 \\
\text { Dec. }\end{array}$} & \multirow{2}{*}{$\begin{array}{c}2000 \\
\text { Dec. }\end{array}$} & \multicolumn{2}{|c|}{2001} & \multicolumn{2}{|c|}{2002} \\
\hline & & & $\begin{array}{r}\text { Sep. } \\
\text { Actual }\end{array}$ & $\begin{array}{r}\text { Des. } \\
\text { Actual }\end{array}$ & $\begin{array}{l}\text { Mar. } \\
\text { Proj. }\end{array}$ & $\begin{array}{l}\text { Dec. } \\
\text { Proj. }\end{array}$ \\
\hline Net foneign assets $1 /$ & 6.0 & 2.8 & .25 & -1.9 & 8.0 & 19.6 \\
\hline (in billions of U.S. dollars) & 11.1 & 4.1 & .1 .6 & -1.3 & 6.0 & 11.3 \\
\hline CBT & 7.5 & 6.6 & -3.1 & -5.4 & 5.2 & 12.1 \\
\hline (in billions of U.S. dollars) & 14.0 & 9.9 & -2.0 & -3.7 & 3.9 & 7.0 \\
\hline Deposit monay barks & -1.6 & -3.9 & 0.6 & 3.5 & 2.8 & 7.5 \\
\hline (in billions of U.S. dollars) & -2.9 & -5.8 & 0.4 & 2.4 & 2.5 & 43 \\
\hline Net domestic assets & 34.2 & 53.3 & 102.1 & 107.5 & 92.8 & 110.2 \\
\hline Net claims on government & 17.0 & 309 & 78.1 & $8 B .9$ & 75.8 & 90.2 \\
\hline Claims on business sector 2 & 18.3 & 31.2 & 37.1 & 38.7 & 36.7 & 46.7 \\
\hline Turtish lira clairss & 11.2 & 21.8 & 20.5 & 23.1 & 22.7 & 29.8 \\
\hline Foneign exchange cliaims (est) y & 7.1 & 9.4 & 16.6 & 15.6 & 14.0 & 16.9 \\
\hline Other items (net) & -1.1 & -8.8 & -13.1 & -20.1 & -19.7 & -26.7 \\
\hline Brosd money (MDY) & 40.2 & 56.0 & 99.6 & 105.7 & 100.8 & 129.9 \\
\hline Lira broad moncy (M2) & 220 & 31.1 & 40.6 & 46.3 & 48.0 & 61.7 \\
\hline Fordign excharge deposits $1 /$ & 18.2 & 24.9 & 59.1 & 59.3 & 52.8 & 68.2 \\
\hline Repos & 4.1 & 6.0 & 4.0 & 2.8 & 3.7 & 4.1 \\
\hline Broad liquidity & 44.2 & 62.0 & 103.7 & 1085 & 104.5 & 134.0 \\
\hline Base money & 3.9 & 5.8 & 7.6 & 7.8 & 8.4 & 10.9 \\
\hline \multicolumn{7}{|l|}{ Memarandum items: } \\
\hline \multicolumn{7}{|l|}{ Annual pereent change } \\
\hline Broad mansy (M2Y) & 98.7 & 39.6 & 91.5 & 88.5 & 42.6 & 22.9 \\
\hline Lixa broad money (M2) & 92.5 & 41.5 & 56.3 & 48.9 & 29.9 & 33.1 \\
\hline Forelgn exchasge deposits $y$ & 106.6 & 37.3 & 126.4 & 137.9 & 56.5 & 14.9 \\
\hline Claims on business sector 2 & 50.8 & 70.3 & 25.6 & 24.2 & 8.8 & 20.7 \\
\hline Net claims on government & 134.2 & 81.7 & 278.5 & 188.0 & 94.9 & 1.5 \\
\hline \multicolumn{7}{|l|}{ In billions of U.S. dothars } \\
\hline Brast money (M2Y) & 74.6 & 83.4 & 65.0 & 73.4 & 75.6 & 74.6 \\
\hline Lin broad maney (Mz) & 409 & 46.3 & 26.5 & 32.2 & 36.0 & 35.5 \\
\hline Foreigh exchange depoxits & 33.7 & 37.1 & 38.5 & 41.2 & 39.6 & 39.2 \\
\hline Net claims on government & 31.6 & 46.0 & 51.0 & 61.8 & 569 & 51.9 \\
\hline Credit to the private sector & 34.0 & 464 & 242 & 26.9 & 275 & 26.8 \\
\hline Base money/GNP 3 & 5.0 & 4.6 & 4.2 & 4,3 & 3.0 & 3.8 \\
\hline Broad money (M2 Y)/GNP 3) & 513 & 44.5 & 55.5 & 58.9 & 35.6 & 45.8 \\
\hline Lira broad mponey (M2)/GNP 3 / & 28.1 & 24.8 & 22.6 & 25.8 & 16.9 & 21.8 \\
\hline \multicolumn{7}{|l|}{ Money multiplier } \\
\hline Brasd money (M2V) & 10.4 & 9.7 & 13.1 & 13.5 & 12.0 & 12.0 \\
\hline Lira broad money (M2) & 5.7 & 5.4 & 5.3 & 5.9 & 5.7 & 5.7 \\
\hline
\end{tabular}

1/ Evahuated at current exchange tates.

$2 /$ Includes crefit to local governments and state econamic enterprises.

3/ Evaluated as pencent of annual average GNP. 


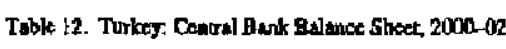

\begin{tabular}{|c|c|c|c|c|c|c|c|c|c|c|c|c|}
\hline & \multirow{3}{*}{$\frac{2000}{\text { Deco }}$} & \multicolumn{4}{|c|}{2001} & \multicolumn{7}{|c|}{2002} \\
\hline & & Merreh & Jone & Seqpt- & Dex. & \multicolumn{2}{|c|}{ Fodruary } & \multicolumn{2}{|c|}{ Aprii } & \multirow{2}{*}{ Prog. } & \multirow{2}{*}{$\begin{array}{c}\text { Sep } \\
\text { Prot. }\end{array}$} & \multirow{2}{*}{$\begin{array}{l}\text { Dec } \\
\text { Ptog }\end{array}$} \\
\hline & & Actonal & Actulal & Actual & Acrual & Prag. & Acoual & Phas & Aatron & & & \\
\hline Ceriurs] Bant bal mact sineer & \multicolumn{12}{|c|}{ 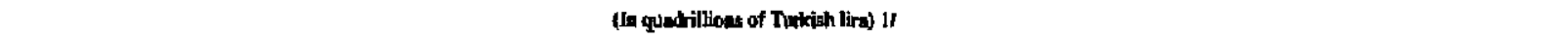 } \\
\hline Nat forcigan wets & 3.3 & 1.2 & .5 .5 & -10.2 & -12.8 & .2 .5 & .1 .7 & -19 & 0.1 & -1.1 & 0.6 & ac \\
\hline Gross fortign asses: & 13.6 & 20.6 & 22.2 & 30.6 & 24.5 & 299 & 31.2 & 30.6 & 33.4 & 31.4 & 32.1 & 328 \\
\hline Oroes farreign isablides & $I 2.3$ & 19.4 & 27.7 & 40.8 & $\$ 1.2$ & 324 & 329 & 32.5 & 332 & 32.5 & 32.7 & 328 \\
\hline Intemetionul rescone liabilitios & 3.1 & 6.1 & $1 \mathrm{H} . \mathrm{F}$ & 19.7 & 20.7 & 11.7 & 11.9 & 11.7 & 119 & 11.7 & 15.7 & 11.7 \\
\hline Oher reserva labilititas 24 & 49 & 5.4 & 6.9 & 10.5 & 10.1 & |fil & 11.6 & 10.1 & 11.5 & 10.1 & 10.1 & 10.1 \\
\hline Barla' foroign axchenge depasibs wih CBT & 4.3 & 7.9 & 8.9 & 10.6 & 10.4 & 10.6 & 9.4 & 10.7 & 9.8 & 10.7 & 109 & 11.0 \\
\hline Net dornestic wsets & 25 & 4.4 & 11.9 & 17.8 & 20.6 & 10.7 & 10.3 & 10.8 & 8.6 & 10.4 & 112 & 10.9 \\
\hline Claims on central goremmant (reat) & 0.4 & $=0.8$ & 17.5 & 22.2 & 31.6 & 22.6 & 25.8 & 22.6 & 25.2 & 22.6 & 226 & 22.6 \\
\hline 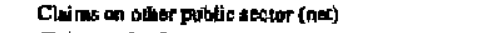 & -0.3 & -0.5 & -0.7 & -8.7 & -1.0 & -1.0 & -0.8 & -1.0 & -1.2 & -1.0 & -10 & -1.0 \\
\hline Clyigns on benks & 5.7 & 10.8 & 0.5 & 2.3 & -20 & -3.1 & -50 & -3.3 & -5.2 & -3.9 & -3.5 & -4.2 \\
\hline Other itensso (net) & -3.3 & -5.0 & 5.1 & -5.9 & -81 & -7.8 & -9.7 & -3.5 & $\cdot 10.1$ & -7.3 & .69 & .65 \\
\hline B mo motny & S.B & 3.6 & 6.4 & 7.6 & 7,8 & $\$ .3$ & 8.6 & 89 & 8.7 & 9.2 & 10.6 & las \\
\hline Currency isused & 3.8 & 3.6 & 4.4 & 5.J & 5.3 & 5.6 & 5.9 & 6.0 & 5.7 & 6.3 & 7.4 & 7.3 \\
\hline 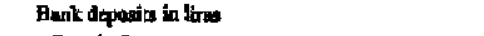 & 2.0 & 2.0 & 2.0 & 25 & 2.5 & 2.7 & 2.7 & 29 & 3.0 & 3.0 & 3.2 & 3.6 \\
\hline Requirtid reserves & 1.4 & 1.2 & 1.3 & 1.4 & 1.6 & 1.8 & 1.7 & 1.5 & j.8 & 2.0 & 2.1 & 23 \\
\hline Free rearaves & 0.6 & 0.8 & 0.7 & I.t & 0.9 & 0.9 & 1.0 & 1.0 & 12 & 1.0 & I.1 & 1.2 \\
\hline Mequanndesin neme: & \multicolumn{12}{|c|}{ (h billione of US. dollene) } \\
\hline Oroas intemslanal mowerves & 23.2 & 19.5 & 37.5 & 200 & 19.8 & 20.8 & 21.7 & 21.8 & 23.2 & 22.3 & 22.8 & 228 \\
\hline 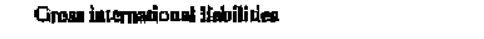 & 183 & 18.4 & 21.9 & 26.6 & 28.6 & 22.5 & 22.9 & 22.6 & 23.1 & 22.6 & 22.7 & 22.8 \\
\hline Nel fortign actions & 4.9 & 1.1 & -4.4 & $.6,7$ & 28.9 & -1.7 & -1.2 & .1 .3 & 0.1 & $-a s$ & -0.4 & $\theta .0$ \\
\hline plus CBT forward postition & 0.0 & .0.3 & 0.0 & 0.0 & 0.0 & 0.0 & 0.0 & 0.0 & 0.0 & 0.0 & 0.0 & 0.0 \\
\hline plas other metorve listiflicas & 7.3 & 5.1 & 5.4 & 69 & 7.1 & 7.1 & 8.1 & $7 . \mathrm{J}$ & 3.0 & 7.1 & 7.1 & 7.1 \\
\hline minus Dreditier ont-year deposilu & 0.6 & 0.6 & 0.6 & 0.6 & 0.7 & 0.7 & $\infty$ & 0.7 & 1.0 & 0.7 & 0.7 & 0.7 \\
\hline minus deforee fond & 0.4 & 0.4 & 0.4 & 0.4 & 0.4 & $0, \mathbf{4}$ & 0.4 & 0.4 & at & 0.4 & 0.4 & 0.4 \\
\hline Net hivemationel macress 3 & 13.1 & 30 & a.1 & -0.9 & -3.0 & 4.2 & 5.6 & 4.6 & 6.7 & 5.1 & 5.5 & 5.9 \\
\hline Net interngyiossal neserves $4 /$ & 11.1 & 4.7 & 0.0 & $\cdot 1.3$ & -3.4 & 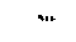 &.. & $\cdots$ & $\cdots$ & $\cdots$ & $m$ & $\cdots$ \\
\hline Definitions in the 2002 protram (CBT plus Trassury) & \multicolumn{12}{|c|}{ (In billims of U.S. dallass) } \\
\hline Net intemadond resectres (Treasury) SN G & ... & $\ldots$ & ... & ... & -13 & -10.7 & -10.5 & -11.8 & -11.6 & -12.9 & .140 & -15.6 \\
\hline Net internationsil reserves (Treanry jow CBT 5 ) & $\ldots$ & $\ldots$ & $\therefore$ & ... & -4.2 & -6.5 & -4.9 & -7.2 & -4.9 & $-7,8$ & -8.5 & -9.7 \\
\hline & \multicolumn{12}{|c|}{ 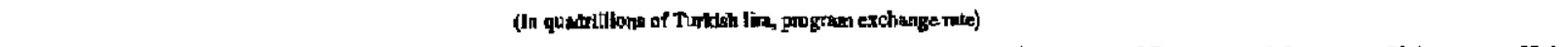 } \\
\hline Net foreign warta (Treasury) & $\cdots$ & $\ldots$ & $\ldots$ & -- & -14 & .19 .4 & -15.1 & -36.9 & -16.7 & -18.5 & $\mathbf{2 0 . 1}$ & $\begin{array}{l}-22,4 \\
-22.4\end{array}$ \\
\hline 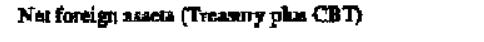 & $\cdots$ & $\cdots$ & $\ldots$ & - & -14.6 & .17 .8 & -16.8 & -18.8 & -16.5 & $\cdot 19.7$ & $-20,7$ & -22.4 \\
\hline Ner domestie absts (Tressiry) $\boldsymbol{\nu}$ & ... & $\cdots$ & $\sim$ & - & 1.8 & 19,4 & 15.1 & 16.9 & 16.7 & 18.5 & 20.1 & $\begin{array}{l}2.4 \\
30.3\end{array}$ \\
\hline Ner domedic ascets (Tresaury phats CBT) & $\cdots$ & $\cdots$ & $\cdots$ & $\cdots$ & 22.4 & 26.1 & 25.4 & 27.7 & 25.2 & 25.9 & 31.3 & 33.3 \\
\hline Base moncy (Treasery plus CBT) & $\ldots$ & -. & ... & $\cdots$ & 7.8 & 83 & 8. 6 & 8.9 & 8.7 & 9.2 & 10.6 & 10.9 \\
\hline Exchunge rate orth per U.S. doller, in millions) & 0.67 & 1.06 & 1.27 & 1.53 & 1.44 & 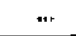 & 1,40 & ... & 1.33 & .- & $\ldots$ & $\cdots$ \\
\hline
\end{tabular}

Sources: Central Bunt of Turteys nod Find staft projections.

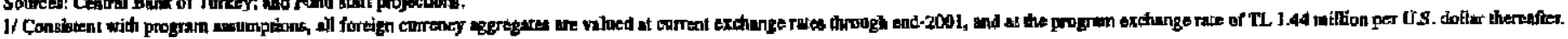

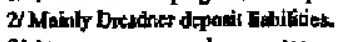

3/Ar anreme cross exchange rates.

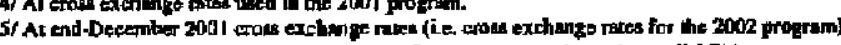

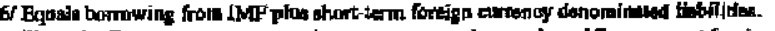

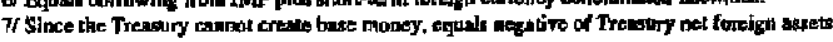

(C) International Monetary Fund. Not for Redistribution 
Table 13. Turkey: Banking System-Selected Indicators, 1998-2001 $1 /$ (In rilliows of Torbish lina)

\begin{tabular}{|c|c|c|c|c|c|c|c|c|}
\hline & \multirow[t]{2}{*}{1995} & \multirow[t]{2}{*}{1999} & \multicolumn{2}{|c|}{2000} & \multicolumn{4}{|c|}{2001} \\
\hline & & & Sep. & $\overline{D_{a C}}$ & Mar. & Jun. & Bep. & $\overline{\text { Dac. }}$ \\
\hline & \multicolumn{8}{|c|}{ Banking System } \\
\hline Total arsets & 40,988 & 79,763 & 108,524 & 117,649 & 132,292 & $164,5 \pm 0$ & 180,709 & 182,265 \\
\hline Oueb and cigims on CBT & 2,665 & 5,097 & 6,199 & 6,235 & 7,788 & 8,847 & 10,895 & 12,699 \\
\hline Gaims on other benks & 3,923 & 7,766 & 12,411 & 13,599 & 13,701 & 18,015 & 17,584 & 17,342 \\
\hline Securities portfolio & 9,688 & 22,040 & 27,185 & 31,251 & 35,089 & 62,170 & 68,643 & 70,779 \\
\hline Loans, net & 14,689 & 22,601 & 34,569 & 35.789 & $\$ 1,043$ & 44,713 & 51,525 & 49,217 \\
\hline Dther asects & 10,024 & 22.258 & 28,161 & 30.775 & 34,670 & 30.835 & 32.063 & 32,228 \\
\hline Total liabilities & 40,988 & 79.763 & 108,524 & 117,649 & 132,292 & 164,580 & 180,709 & 182,265 \\
\hline Deposits & 24,194 & 48,272 & 65,298 & 68,143 & 80.27 & 96,380 & 113,128 & 117,150 \\
\hline Borrowizg from banks & 4,663 & 10,070 & 14,567 & 15,996 & 21,126 & 23,376 & 24,691 & 18,200 \\
\hline Repas & 4,153 & 7,645 & 11,952 & 12,843 & 11,250 & 12,702 & 10,979 & 10,674 \\
\hline Other liabilities & 4,689 & 9,539 & 10,574 & 12,207 & 14,571 & 15,726 & 16,898 & 19,477 \\
\hline Sharebolders' equity (including profits) & 3,290 & 4,235 & 6,133 & 8,461 & 5,108 & 16,397 & 15,613 & 16,762 \\
\hline \multicolumn{9}{|l|}{ Memarandum items: } \\
\hline Capital adequacy ratio (in percent) & $\ldots$ & $\ldots$ & 8.3 & 173 & 7,7 & 20.3 & 16.8 & $\ldots$ \\
\hline NRLs (in percent) total loans & 6.7 & 9.7 & 8.7 & 9.2 & 8.7 & 13.6 & 15.6 & 126 \\
\hline Provigions (in perceni) NPLs & 44.2 & 61.9 & 57.6 & 59.8 & 58.2 & 67.4 & 65.4 & 65.7 \\
\hline Net profit (losis) after $\operatorname{tax}$ & 760 & -305 & -705 & -888 & 4669 & -4925 & -5107 & $-3,546$ \\
\hline ROA (in poncent) & 19 & -0.4 & -0.6 & 208 & -3.5 & -3.0 & 28 & -19 \\
\hline ROE (in percent) & 23.1 & -7.2 & -11.5 & -105 & -91.3 & -30.0 & -327 & -212 \\
\hline Share in assets (in pencent) & 100 & 100 & 100 & 100 & 100 & 100 & 100 & 100 \\
\hline Share in deposits and tepos (its percent) & 100 & 100 & 100 & 100 & 100 & 100 & 100 & 100 \\
\hline & \multicolumn{6}{|c|}{ Private Bmiks 2y } & . & \\
\hline Totel aisats & $\mathbf{2 5 , 5 9 6}$ & 42,165 & 60.235 & 56,179 & 60,338 & 79,505 & 91,741 & 99,946 \\
\hline Cash and chaims on CBT & 1,514 & 2,707 & 3,627 & 3,362 & 4,574 & 5,579 & 6,844 & 8.537 \\
\hline Claims ot other banks & 2,688 & 5,386 & 8,317 & 9,769 & 9,851 & 12,695 & 10,712 & 10,352 \\
\hline Securities portfolio & 6,478 & 14,335 & 17,053 & 13,491 & 13,407 & 16,165 & 23,178 & 27,494 \\
\hline Loans, net & 8,793 & 12,445 & 20,915 & 19,587 & 22,696 & 27,014 & 31,939 & 31,781 \\
\hline Other Bssets & 4,124 & 7,292 & 10,323 & 9,971 & 15,809 & 18,449 & 21,068 & 21,782 \\
\hline Tolal tiabilities & 23,596 & 42,165 & 60,233 & 56.179 & 66,338 & 79,903 & 93,741 & 99,946 \\
\hline Depotits & 13,652 & 23,160 & 32,745 & $30, \$ 27$ & 40,490 & 51,189 & 69.659 & 71,361 \\
\hline Bornowing from banks & 3,006 & 6,508 & 9,323 & 10,045 & 12,750 & 14,137 & 13,586 & 11,769 \\
\hline Repos & 2,633 & 4,654 & 6.766 & 3,918 & 700 & 2,355 & 2,820 & 1.758 \\
\hline Other Liabilitios & 1,894 & 3,036 & 3,704 & 3,503 & 4,708 & 4,374 & $\$, 057$ & 5,391 \\
\hline Skaneholders' equity (including profits) & 2,411 & 4,806 & 7,697 & 7,886 & 7,690 & 7,848 & 8,619 & 9,667 \\
\hline \multicolumn{9}{|l|}{ Memarandum iterns: } \\
\hline Capllat adequacy ratio (in pencent) & $\ldots$ & $\ldots$ & 16.7 & 18.3 & 15.9 & 10.6 & 10.9 & $\ldots$ \\
\hline NPLs (in percent) total lowiols & 6.9 & 3.5 & 3.4 & 35 & 3.8 & 4.5 & 4.4 & 53 \\
\hline Provisions (in pereen) NPLS & 412 & 62.2 & 69.3 & 63.0 & $\$ 2.5$ & 45.4 & 45.2 & 46.1 \\
\hline Net profit (lass) after tax & 660 & 1618 & 632 & 1276 & 181 & 66 & 753 & $1,166,3$ \\
\hline ROA (is pertall) & 2.8 & 3.8 & 1.0 & 2.3 & Q3 & 0.1 & 0.8 & 1.2 \\
\hline ROE (in pereent) & 27.4 & 33.7 & 8.2 & 16.2 & 2.4 & 0.8 & 8.8 & 12.1 \\
\hline Shere in prsets (in percent) & 57.6 & 529 & 55.5 & 47.8 & 50.1 & 485 & 51.9 & 54.8 \\
\hline Share in depoelts and repos (in percent) & 57.4 & 49.7 & 51.1 & 42.9 & 450 & 49.1 & 53.6 & 572 \\
\hline
\end{tabular}


Table 13 (continued). Turkey: Banking System - Selected Indicators, 1998-2001 if (in trillions of Turkish tira)

\begin{tabular}{|c|c|c|c|c|c|c|c|c|}
\hline & \multirow[t]{2}{*}{1998} & \multirow[t]{2}{*}{1999} & \multicolumn{2}{|c|}{2000} & \multicolumn{4}{|c|}{2001} \\
\hline & & & Sep. & $\overline{\text { Dec. }}$ & Mar. & Jun. & Sep. & Dec. \\
\hline & \multicolumn{8}{|c|}{ Stake Bunks $3 i$} \\
\hline Total assets & $14,1,50$ & 27,104 & 37,362 & 40,605 & 42,052 & 47,911 & 51,710 & 57,676 \\
\hline Cash and clains on CBT & 1,067 & 1,999 & 2,377 & $2,58 \mathrm{~B}$ & 2,670 & 2,761 & 3,367 & 3,544 \\
\hline Claims on other banks & 652 & 1,088 & 2.257 & 1,639 & 1,835 & 2,427 & 4,227 & 4,693 \\
\hline Securities portfolio & 2,660 & 4,671 & 7,070 & 8,139 & $1 \mathrm{1}, 551$ & 26,386 & 27,732 & 32.791 \\
\hline Loabs, net & 4,267 & 6.521 & 9,331 & 10,025 & 10.744 & 9.662 & 10.428 & 19,006 \\
\hline Other assers & 5,503 & 12,825 & 16,327 & 18,265 & 15,253 & 6,675 & 6,156 & 6,641 \\
\hline Toual jabilities & 14,150 & 27,104 & 37,362 & 40,655 & 42,052 & 47,911 & 51,710 & 57,676 \\
\hline Depasios & 9,838 & 19,204 & 25,562 & 27,606 & 29,219 & 29,294 & 33,479 & 37,905 \\
\hline Borrowing from banks & 363 & 630 & 1,369 & 1,339 & 2,2007 & 1,621 & 1,812 & 1,865 \\
\hline Repos & 1,284 & 1,922 & 4,446 & 4,949 & 6,191 & 7,995 & 5,566 & 3,844 \\
\hline Other liebilites & $2,[1] 6$ & 4,317 & 4,825 & 5,659 & 6,025 & 6.737 & 6,692 & 9.513 \\
\hline Shareholders' equity (including profita) & 544 & 1,031 & 1,159 & 1.101 & $-1,591$ & 2,263 & 4,161 & 4,549 \\
\hline \multicolumn{9}{|l|}{ Memornndum itrms; } \\
\hline Capital adequacy ratio (in percent) & .. & 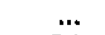 & & 7.9 & -1.6 & 26.8 & 26.8 & $\ldots$ \\
\hline NPLs (in percenit) total loans & 5.3 & 9.1 & 11.3 & 11,1 & 122 & 22.3 & 28.1 & 29 \\
\hline Provisions (in percent) NPLs & $30: 2$ & 35.1 & 26.3 & 30.3 & 42.7 & 59.1 & 50.8 & 66 \\
\hline Net profit (loss) after tax & 78 & 284 & 41 & -177 & -3028 & -955 & -407 & -21 \\
\hline ROA (in percent) & 0.5 & 1.0 & 0.1 & 0.4 & -7.2 & -2.0 & -0.8 & 0.0 \\
\hline ROE (in percent) & 14.3 & 27.6 & 3.5 & -16.1 & thr & -42.2 & -9.8 & -0.5 \\
\hline Share in assels (in percent) & 34.5 & 34.0 & 34.4 & 34.6 & 31.8 & 29.1 & 23.6 & 31.6 \\
\hline Share in depogits and repos (in percent) & 39.2 & 37.8 & 38.8 & 40.2 & 38.7 & 34,2 & 31.5 & 32.7 \\
\hline & \multicolumn{8}{|c|}{ SOFF Banks 4} \\
\hline Totenl asucts & 667 & 3,480 & 4,042 & 12,912 & 14,037 & 25.916 & 22,399 & 11,736 \\
\hline Cash and claims on CBT & 9 & 248 & 43 & 103 & 194 & 134 & 125 & 89 \\
\hline Chims on other banks & 47 & 211 & 252 & 535 & 479 & 1,186 & 501 & 893 \\
\hline Securides portfolio & 351 & 2,511 & 2,119 & 8,572 & 9.212 & 18,738 & 16,744 & 8,883 \\
\hline Loans, net & 158 & 1,052 & 979 & 2,533 & 2,750 & 2,327 & 2,314 & 656 \\
\hline Other aqsets & 102 & 1,458 & 650 & 1,169 & 1,402 & 3,531 & 2,716 & 1,214 \\
\hline Toual liabilities & 667 & 5,480 & 4,042 & 12,912 & 14,037 & 25,916 & 22,399 & {$[1,736$} \\
\hline Deposits & 446 & 5,363 & 6,327 & 8.827 & 9,361 & 14,523 & 14,157 & 5,475 \\
\hline Bartowing from banks & 29 . & 263 & 367 & 819 & 1,824 & 3.272 & 3,767 & 396 \\
\hline Repos & 226 & 1,426 & 964 & 3.993 & 4,307 & 2,299 & 2,524 & 5,023 \\
\hline Other liabilities & $\boldsymbol{\theta}$ & 968 & 587 & 1,329 & 1,294 & 1,546 & 1,400 & 884 \\
\hline Shareholders' equity (including profits) & -104 & $-2,540$ & $-4,204$ & $-2,056$ & $-2,749$ & 4,276 & 551 & -43 \\
\hline \multicolumn{9}{|l|}{ Memorandum items: } \\
\hline Capital adequacy noto (ton percent) & $\ldots$ & $\ldots$ & $\ldots$ & $\ldots$ & $\ldots$ & 72.3 & 30.0 & $\ldots$ \\
\hline NPLS (in percesin) total loans & 49.7 & 61.9 & 64.6 & 41.4 & 36.8 & 59.2 & 68.7 & 64.9 \\
\hline Provisions (in percent) NPLs & 80.9 & 75.3 & 78.2 & 80.3 & 772 & 85.8 & 86.5 & 89.1 \\
\hline Nes profit (loss) after tix & -127 & -2547 & -1697 & -2314 & -2048 & -4883 & -6172 & -5.112 \\
\hline ROA (in pencent) & -19.0 & -46.5 & -42.0 & -17.9 & $-14,6$ & $.17,3$ & -27.6 & -43.6 \\
\hline ROE (in percent) & $\ldots$ & $\ldots$ & $\ldots$ & $\ldots$ & $\cdots$ & -104.8 & $-1,120.0$ & ... \\
\hline Share in assets (in peccent) & 1.6 & 6.9 & 3.7 & 11.0 & 10.6 & 15.7 & 12.4 & 6.4 \\
\hline Share in deposits and repos (in percent) & 24 & 12.1 & 9.4 & 15.8 & 14.9 & 15.4 & 13.4 & 8.2 \\
\hline
\end{tabular}


Table 13 (concluded). Tukey: Bunking \$ystern-Selected Indicators, 1998-2001 11 (in trilitions of Turtish lirs)

\begin{tabular}{|c|c|c|c|c|c|c|c|c|}
\hline & \multirow[t]{2}{*}{1998} & \multirow[t]{2}{*}{1999.} & \multicolumn{2}{|c|}{2000} & \multicolumn{4}{|c|}{2001} \\
\hline & & & Sep. & Dech & Mar. & Junl. & Sep. & Dec: \\
\hline & \multicolumn{8}{|c|}{ Forcign and Investment Banks } \\
\hline Tocal arsels & 2.576 & 5,014 & 6,886 & 7,903 & 9,864 & 10,850 & 12,860 & 12,908 \\
\hline Cash and claims on CBT & 75 & 143 & 152 & 182 & 350 & 973 & 739 & 530 \\
\hline Claims on other banks & 536 & 1,082 & 1,585 & 1,657 & 1,597 & 1,707 & 2,143 & 3,403 \\
\hline Securities portfolio & 199 & 523 & 942 & 1.049 & 919 & 880 & 989 & 1,610 \\
\hline Loens, net & 1,471 & 2,583 & 3,344 & 3,645 & 4,853 & 5,750 & 6,844 & 6,774 \\
\hline Other asets & 295 & 683 & 862 & 1,370 & 2,206 & 2,179 & 2.124 & 2.591 \\
\hline Torat linbilities & 2,576 & 5,014 & 6,886 & 7,903 & 9,864 & 10,850 & 12,860 & 12,908 \\
\hline Deporits & 258 & 546 & 664 & 882 & 1,207 & 1,374 & 1,832 & 2,409 \\
\hline Borrowing from banks & 1,259 & 2,670 & 3,507 & 3.792 & 4,345 & 4,346 & 4,926 & 4,173 \\
\hline Repos & 10 & -357 & -224 & -17 & 11 & 52 & 69 & 48 \\
\hline Other liabilitios & 609 & 1,218 & 1.458 & 1,716 & 2,544 & 3,068 & 3,750 & 3,689 \\
\hline Shrreholders' equity (including profits) & 439 & 937 & 1.481 & 1529 & 1.758 & 2,010 & 2,283 & 2589 \\
\hline \multicolumn{9}{|l|}{ Memocandum itenx: } \\
\hline Capital adequany ratio (in percent) & $\ldots$ & $\ldots$ & 28.7 & 29.4 & 29.8 & 31.3 & 295 & $\ldots$ \\
\hline NPLs (in percent) total loans & 21 & 2.1 & 2.2 & 1.8 & 2.1 & 28 & 2.9 & 6.6 \\
\hline Provisionis (in percent) NPLs & 540 & 31.3 & 43.2 & 51.8 & 55.8 & 45.5 & 45.6 & 81.0 \\
\hline Nel profit (loss) after tax & 150 & 340 & 320 & 328 & 231 & 447 & 717 & 420 \\
\hline ROA (In percent) & 58 & 6.8 & 4.6 & 4.1 & 23 & 4.1 & 5.6 & $\mathbf{3 . 3}$ \\
\hline ROS (in percent) & 34.1 & 36.3 & 21.6 & 21.4 & 13.2 & 22.2 & 31.4 & 16.2 \\
\hline Share in astess (in percent) & 63 & 6.3 & 6.3 & 6.7 & 7.5 & 6.6 & $T_{1} 1$ & 7.] \\
\hline Share in deposits and repos (in porcent) & 0.9 & 0.3 & 0.6 & 1.1 & 13 & 1.3 & 15 & 1.9 \\
\hline
\end{tabular}

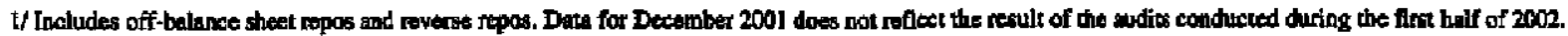
I/ Comprises the privalte (dornestie) deposil-mining commereis banks.

3/ These include 3 state benies (Emikk Bank was closed and its assets and liabilities merged with Ziraat Bank) 


\section{TURKeY: Fund Relations}

(As of April 30, 2002)

I. Membership Status: Turkey became a member of the Fund on March 11, 1947. It has accepted the obligations of Article VIII, Sections 2, 3, and 4 as of March 22, 1990.

II. General Resources Account:

Quota

Fund holdings of currency

Reserve position in Fund

\author{
Millions of SDRs \\ 964.00 \\ $15,361.69$ \\ 112.78
}

Millions of SDRs

112.31

18.73

Holdings

IV. Outstanding Purchases and Loans:

Stand-by Arrangements

First credit tranche
Millions of SDRs

$14,148.96$

361.50
Percent of Quota

100.00

$1,593.54$

11.70

\section{Percent of Quota $1,467.73$ \\ 37.50}

V. Financial Arrangements:

$\begin{array}{cc}\text { Type } & \text { Approval } \\ \text { Date } & \text { Date }\end{array}$

$\begin{array}{lll}\text { Stand-By } & 02 / 04 / 02 & 12 / 31 / 04 \\ \text { Stand-By } & 12 / 22 / 99 & 02 / 04 / 02 \\ \text { Of which: SRF } & 12 / 21 / 00 & 12 / 20 / 01 \\ \text { Stand-By } & 07 / 08 / 94 & 03 / 07 / 96\end{array}$

\begin{tabular}{cr}
$\begin{array}{c}\text { Amount } \\
\text { Approved }\end{array}$ & $\begin{array}{r}\text { Amount } \\
\text { Drawn }\end{array}$ \\
\hline In millions of SDRs \\
$12,821.20$ & $8,194.00$ \\
$15,038.40$ & $11,738.96$ \\
$5,784.00$ & $5,784.00$ \\
610.50 & 460.50
\end{tabular}

VI. Projected Obligations to Fund:

Under the Repurchase Expectations Assumptions ${ }^{1}$

(In millions of SDRs; based on existing use of resources and holdings of SDRs)

\begin{tabular}{llll}
\multicolumn{4}{c}{ Forthcoming } \\
\hline $2002 \quad 2003$ & 2004 & 2005 & 2006
\end{tabular}

Principal

Charges/Interest

\begin{tabular}{rrrrr} 
& $1,223.90$ & $6,122.50$ & $6,031.30$ & $1,132.70$ \\
478.40 & 653.80 & 524.50 & 197.40 & 12.70 \\
\hline 478.40 & $1,877.70$ & $6,647.00$ & $6,228.70$ & $1,145.40$
\end{tabular}

\footnotetext{
${ }^{1}$ Disbursements made after November 28,2000 -with the exception of disbursements of emergency assistance and loans from the Poverty Reduction and Growth Facility - are expected to be repaid on the expectations schedule. Countries may request the IMF Executive Board to make repayments according to the obligations schedule if their external payments position is not strong enough to meet the repayment expectations without undue hardship or risk. Please note: Repayments under the Supplemental Reserve Facility are scheduled to be repaid on the expectations schedule.
} 
VII. Safeguard Assessments:

Under the Fund's safeguards assessment policy, the Central Bank of Turkey was subject to the transitional procedures with respect to the SBA approved on December 22, 1999, which was scheduled to expire on December 21, 2002. The transitional procedures require a review of only the CBT's external audit mechanism. This assessment determines whether the CBT publishes annual firancial statements that are independently audited in accordance with internationally accepted standards.

The External Audit assessment was completed on August 21, 2001. The assessment concluded that the Central Bank of Turkey's current external audit mechanism may not be adequate in certain respects and appropriate recommendations have been made to the authorities, as reported in EBS/01/192, 11/21/01.

Under the new SBA, approved on February 4, 2002 the CBT was subject to a full safeguards assessment, which entails two phases. Stage One (off-site assessment) was completed on February 25, 2002 and recommended completion of Stage Two (on-site assessment). The latter was completed on April 4, 2002 ahead of the Board discussion on the First Review under the program as mandated by the Fund's safeguards assessment policy. The conclusions of the on-site assessment are reported in Section IV of EBS/02/61.

\section{Exchange Rate Arrangement:}

For the period January 1, 2000-June 30, 2001, the lira was to have depreciated against a basket comprising US $\$ 1$ and $€ 0.77$ along a daily path preannounced by the central bank. The preannouncement was for the 12-month period, and was updated quarterly. There would not be an exchange rate band around the preannounced path during the first 18 months of the program. Thereafter-that is, from July 1, 2001-a symmetrical intervention band was to have been introduced around the central parity rate, with the total width of the band increasing gradually at a rate of 15 percentage points per year. This exchange rate arrangement was in place until February 22, 2001, when the government decided to float the currency.

IX. Article IV Consultations:

The 1999 Article IV staff report (EBS/99/225) was issued on December 10, 1999, the accompanying Selected Issues and Statistical Appendix (SM/99/294) was issued on December 14, 1999. Board discussion took place on December 22, 1999 (EBM/99/137). 


\section{ROSCs}

\section{Standard or Code Assessed}

Fiscal Transparency

Corporate Governance

(prepared by the World Bank)

Data Dissemination
Date of Issuance

June 26, 2000

December 11,2000

March 14, 2002
Document Number

SM/00/139

XI. Technical Assistance: (1993-present)

Department

MAE

MAE

FAD

FAD

STA

PDREU1/

MAE

MAE

MAE

MAE

MAE

FAD

FAD

MAE

MAE
Timing

July 1994

July 1995

September 1995

October 1995

February 1997

December 1998

June 1999

August 1999

October 1999

March 2000

April 2000

Apri1 2000

April 2000

May 2000

\section{Purpose}

Banking sector reform

Inflation accounting

Taxation of petroleum products

Assistance to IBRD Public Financial Managing Project; 8 FAD missions since 1994, assignment of 5 resident experts, mainly focused on customs modernization

Balance of payments compilation

Short-term debt monitoring

Basel Core Principles

Debt management policies

Banking sector reform

Banking sector reform

Fiscal transparency

Tax policy

Banking sector reform

Banking sector reform 
Department

MAE

STA

MAE

MAE

FAD/STA

MAE/RES

STA

MAE/RES
Timing

July 2000

September 2000

Sept. 2000-April 2001

April 2001

May 2001

September 2001

April 2002

April/May 2002

\section{Purpose}

Inflation targeting

Balance of payments statistics

Banking sector reform

Debt management

Fiscal accounting and reporting

Inflation targeting

National accounts statistics

Inflation targeting 


\section{TURKEY: RELATIONS WITH THE WORLD BANK GROUP}

\section{LENDING ASSISTANCE}

\section{A. IBRD}

1. The World Bank Group's assistance program to Turkey is guided by the revised Country Assistance Strategy (CAS) discussed by the Bank's Board of Directors in July 2001. The revised CAS includes additional IBRD support on Special Structural Adjustment Loan (SSAL) terms of up to US\$1.2 billion, for a total possible lending of US\$6.2 billion in the period FY2001-03, of which US\$4.1 billion was committed as of May 2002. Delivery of this expanded assistance program is fully on track. Policy based lending in the revised CAS is centered around the Programmatic Financial and Public Sector Adjustment Lending (PFPSAL) program, which focuses on structural and institutional reforms in the banking and public sectors. The first PFPSAL of US\$1.1 billion was approved by the Bank's Board and disbursed in a single tranche in July 2001. The second PFPSAL in the amount of US\$1.35 billion bas been approved in April 2002. The second PFPSAL is designed as a three-tranche operation. Follow-up programmatic operations to support continuation of the Government's financial sector reform and public sector reform programs are envisaged during the remainder of the current CAS period. The World Bank Group is preparing a new CAS (for FY2003-05), which will be completed in the Fall of 2002.

2. The revised CAS also features increased support for social protection in response to the economic crisis. It includes the US $\$ 250$ million Privatization Social Support project approved in December 2000, the US\$500 million Social Risk Mitigation project approved in September 2001, and additional lending for health, education, community development and watershed protection.

3. The IBRD lending program also includes sustained support for structural reforms to promote private sector development. It comprises the US\$375 million second tranche of the Economic Reform Loan and the US\$600 million Agriculture Reform Implementation project approved in July 2001.

\section{B. IFC}

4. The IFC maintains a strong investment presence in Turkey. It accounts for about 4.5 percent of the total IFC portfolio. The total IFC own-account held portfolio in Turkey is currently US $\$ 630$ million and the outstanding balance of syndicated loans mobilized by IFC is US\$391 million. IFC has also invested over US\$150 million in Turkish companies outside of Turkey in neighboring countries of the CIS and the Balkans.

\section{MIGA}

5. The activities of MIGA are a key element of the World Bank Group's assistance program. Turkey's share of MIGA's portfolio is about US\$165 million (gross), representing approximately 4 percent of the total portfolio. While MIGA's exposure is currently 
concentrated in the financial sector, the agency continues efforts to extend coverage to infrastructure and services projects.

\section{NONLENDING AsSistance}

6. The World Bank Group has a very active nonlending services program in Turkey. Major economic and sector work recently undertaken include the Country Economic Memorandum on Structural Reform for Sustainable Growth completed in 2000, as well as the Public Expenditure and Institutional Review, the Country Procurement Assessment Report and the Country Financial Accountability Assessment, all completed during the Summer of 2001. The World Bank finalized a Corporate Assessment, which has contributed to the development of the authorities' strategy ("Istanbul approach") on corporate sector restructuring. A Non-Bank Financial Institutions study and a new Country Economic Memorandum are to be prepared in 2002. The World Bank sponsored an international conference on good governance and combating corruption in September 2001, and a second international conference on public expenditure management was held in December 2001. The Foreign Investment Advisory Service (FIAS) carried out a Diagnostic of the Foreign Investment Climate in Turkey and an Administrative Barriers Study during the course of 2001. The World Bank is assisting the Government in the creation of an Investor Council whose first meeting is scheduled for July 2002 . 


\section{Turkey: Recent Developments in External and Financial Vulnerability}

1. Through May, access to international and domestic capital markets was better than expected (Tables 14 and 15). In the first five months of 2002, Turkey tapped the international capital market for US $\$ 2.2$ billion, covering more than 70 percent of the programmed issuance of sovereign debt for the whole year. In domestic debt auctions, private sector rollover was over 100 percent, much higher than originally envisaged. Both domestic and sovereign issues saw a marked reduction in their yields, accompanied by a lengthening of maturities. Access by the private sector was also maintained through the stabilization of extemal interbank credit lines, following a decline of some US\$8 billion in 2001. External loans due over the next month by Turkish banks have been falling, and foreign banks' exposure has been broadly maintained. Also, dollarization of the economy has been gradualiy reversing, although at a slower pace in recent months.

\section{Recent political uncertainty has led to a reversal of the improvement in financial} indicators achieved earlier in the year (Figures 12 and 13). Between October 2001 and April 2002, the term structure of interest rates gradually shifted downward and became flatter, reflecting falling inflation expectations and risk premia as program credibility strengthened. Owing to recent political uncertainties, bowever, the yield curve for May moved upward and turned steeper, exchange rate volatility increased, and spreads on Eurobonds saw a reversal of earlier gains. After a surge in late 2001 and early this year, stock market performance has been anemic over the last few months.

3. Banking sector indicators have been mixed (Table 16). Net foreigu exchange open positions have been gradually closed both in SDIF banks, and private and public banks and remain well within prudential limits. Nonperforming loans have somewhat increased over the last few months, mainly in non-SDIF banks, while a slight smaller percentage of them has been provisioned for. (These figures do not reflect the recently concluded audits by the BRSA, which show much higher NPL ratios for private banks.) Over the same period, the ratio of net (provisioned for) nonperforming loans to credit to the private sector has also increased, albeit modestly, but credit to the private sector as a share of total deposit has remained virtually unchanged. 
Figure 12. Turkey: Term Structure of Interest Rates, 2001-02
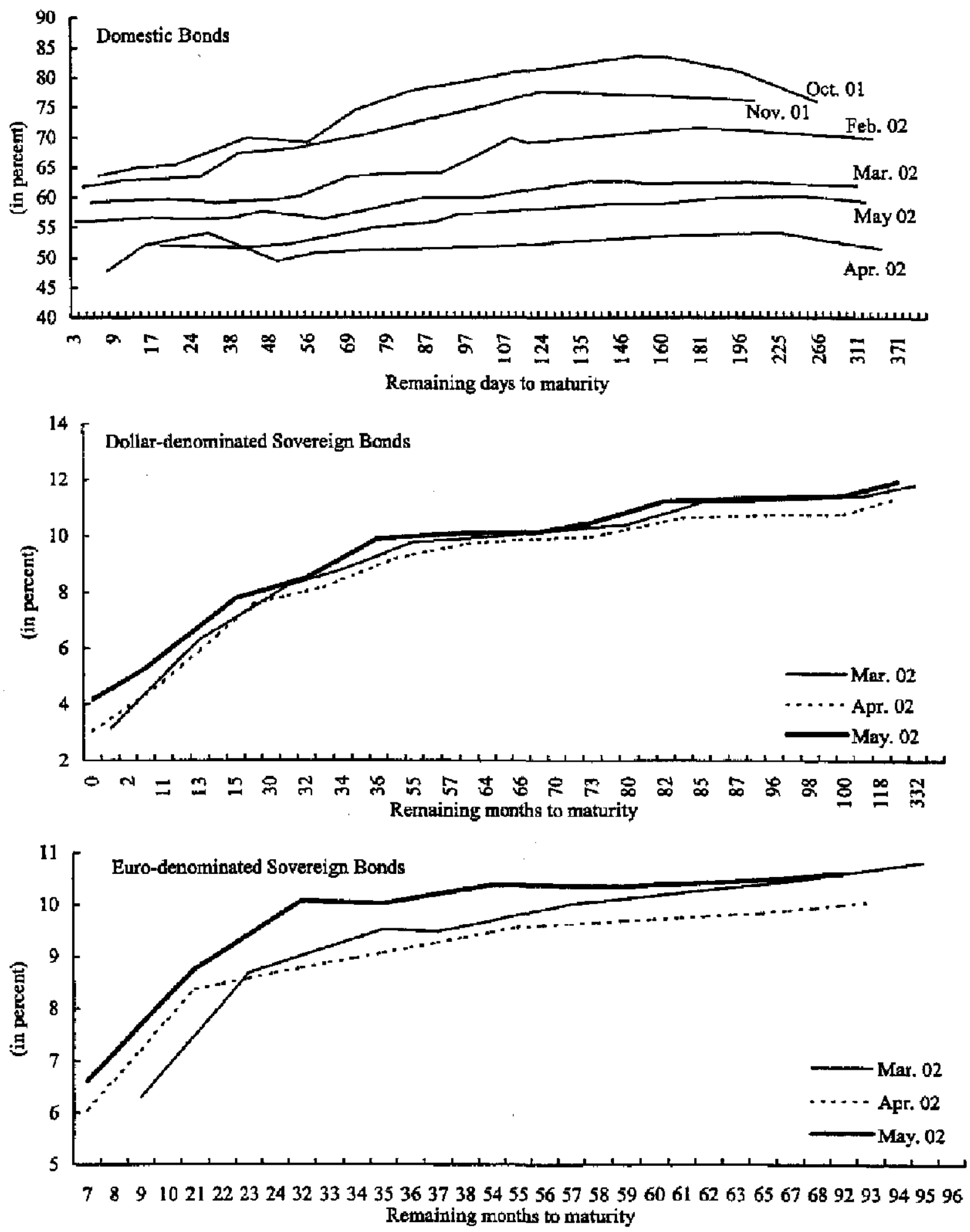

Source: Date from the Turkish authorities; Bloomberg; and Fund staff estimates. 
Figure 13. Turkey: Recent Financial Market Developments, 2001-02
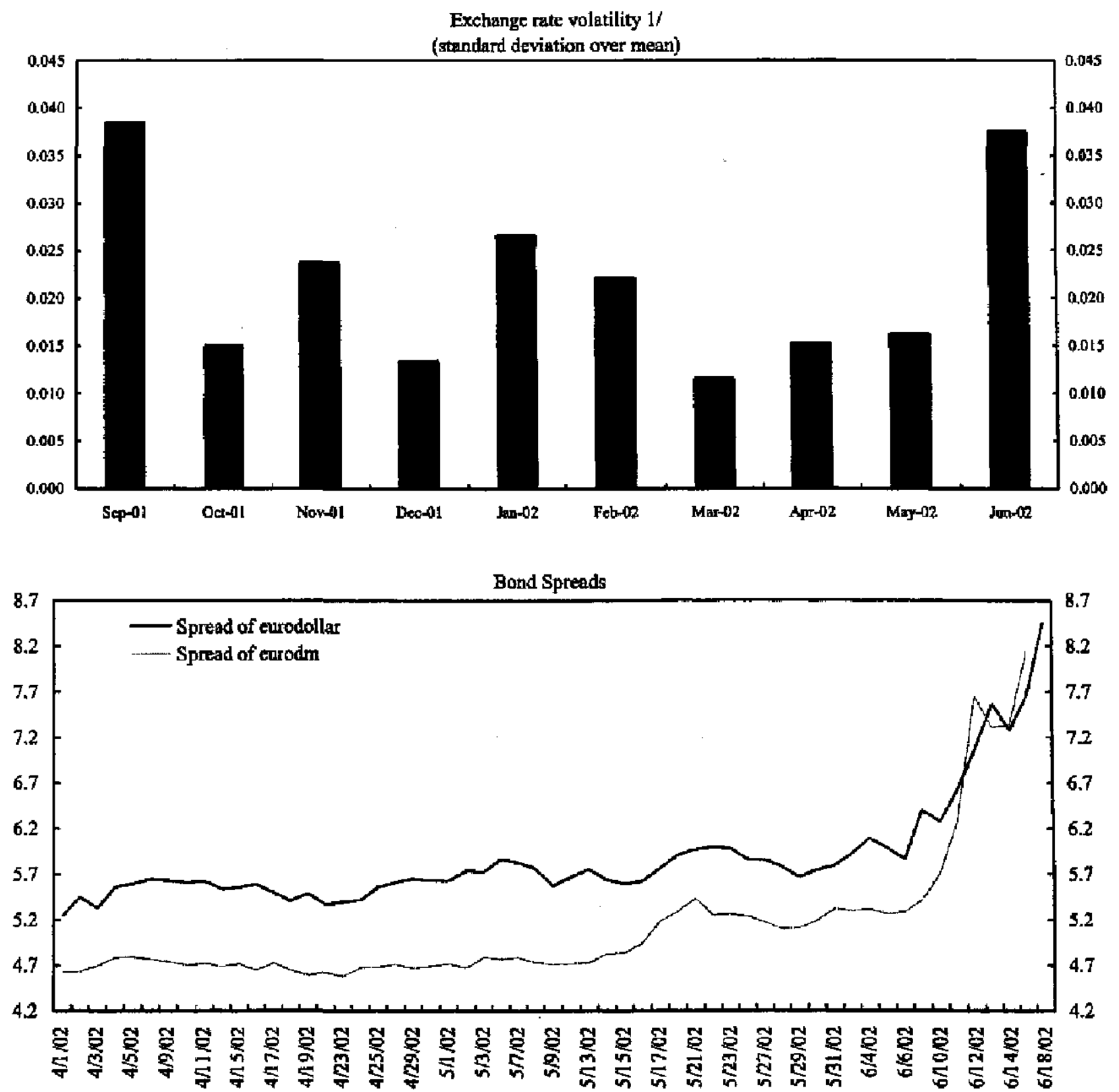

Source: Central Bank of Turkey; and Bloomberg.

1/ For June 2002, up to June 19. 
Table 14. Turkey: Public Sector Financing Indicators, 2001-02

\begin{tabular}{|c|c|c|c|c|c|c|c|}
\hline & \multirow[t]{2}{*}{2001} & \multicolumn{6}{|c|}{2002} \\
\hline & & January & Febnuary & March & April & May & Cumulative \\
\hline & \multicolumn{7}{|c|}{ (In millions of U.S. dollars) } \\
\hline \multicolumn{8}{|l|}{ External } \\
\hline Sovereign bond issuance & 2,200 & 600 & 250 & 600 & 0 & 700 & 2,150 \\
\hline Euro denominated & $\ldots$ & 0 & 0 & 0 & 0 & 700 & 700 \\
\hline U.S. dollar denominated & $\ldots$ & 600 & 250 & 600 & 0 & 0 & 1,450 \\
\hline \multirow[t]{2}{*}{ Cumulative sovereign issuance as share of total program issuance 1/ } & $\ldots$ & 20 & 28 & 48 & 48 & 72 & 72 \\
\hline & \multicolumn{7}{|c|}{ (In quadrillions of Turkish lira, unless otherwise indicated) } \\
\hline \multicolumn{8}{|l|}{ Domestic } \\
\hline Treasury deposits at the CBT & 2.6 & 2.9 & 3.2 & 3.2 & 5.3 & 4.0 & \\
\hline \multicolumn{8}{|l|}{ Ratio of new domestic borrowing to redemptions (incl. interest) } \\
\hline Total & 77.0 & 100.0 & 67.4 & 95.1 & 103.6 & $\cdots$ & \\
\hline Private sector & 90.7 & 116.7 & 103.6 & 113.0 & 131.7 & $\cdots$ & \\
\hline Bid-cover ratio in Treasury bill auctions (in percent) & 154.4 & 125.5 & 194.9 & 131.2 & 141.3 & 120.0 & \\
\hline Gross monthly redemptions (valued at constant end-2001 Turkish lira) & 7.0 & 7.6 & 4.3 & 5.6 & 7.6 & 8.6 & \\
\hline
\end{tabular}

Sources: Data provided by the Treasury; and Fund staff estimates.

1/ Program projection for sovereign issuance in 2002 is US\$3 billion. 
Tabbe 15. Twkey: Banking Seetor External Indicators, 2001-02

\begin{tabular}{|c|c|c|c|c|c|c|c|c|c|c|c|c|c|c|c|c|c|}
\hline & \multicolumn{12}{|c|}{$200 \mathrm{I}$} & \multicolumn{5}{|c|}{2002} \\
\hline & Jan. & Feb. & March & April & May & June & July & Aug. & Seph. & Det. & Nov. & Dec. & Jan. & Feb. & March & April & May \\
\hline & \multicolumn{17}{|c|}{ (In millions of U.S. dollars, unless otherwise indizated) } \\
\hline Bunks' external louns due next month $1 /$ & 6,490 & 5,765 & 5,515 & 5,591 & 4.242 & $5,29 \mathrm{~L}$ & 1,383 & 1,520 & 2,555 & 1.073 & 1,743 & 1.106 & 700 & 515 & 281 &. & .. \\
\hline Change in foreign banks' exposure $1 /$ & -281 & $-1,525$ & -933 & -172 & -885 & $-1,841$ & $-2,001$ & 422 & -3.677 & 2,253 & 402 & -392 & -165 & -85 & 156 & -279 & 688 \\
\hline Credit line roll-aver ratio (in percent) $2 y$ & 98.8 & 97.1 & 95.7 & 97.3 & 96.2 & 91.9 & 76.2 & 98.9 & 96.3 & 93.3 & 105.7 & 89.9 & 98.8 & 98.1 & 98.4 & 95.4 & t 10.0 \\
\hline Ratio of fx depasits to total deposits (in percent) $3 /$ & 45.0 & 49.2 & 48.5 & 52.0 & $\mathbf{5 1 . 4}$ & 34.3 & 58.0 & $5 B .4$ & 60.8 & 61.6 & 59.4 & 56.6 & 55.0 & 55.5 & 53.6 & 53.5 & 54.7 \\
\hline
\end{tabular}

Sources: Date provided by the Contral Bank of Turkey; the BRSA; and Fund staff ertimates.

1/ For May 2002, up to May 22

$2 /$ For May 2002, as of May 29.

$3 /$ For May 2002, as of May 31. 


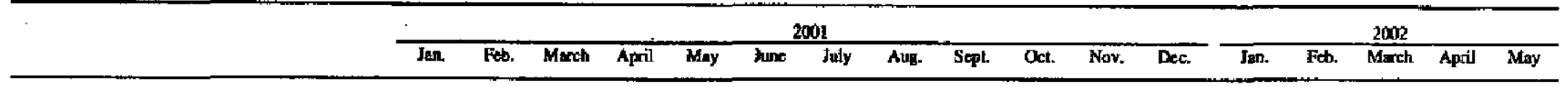

Not foreifn exchange open position 1 t

Banking sector

Net foreign exchange oper position

In perconta of copital base

SDIF hanks

Net fortignt exchange open position

In parcent of capital baso

Non-SDIF banks

Net fortignt exchange opan position

In percent of capiral base

Nonperforming loans $2 t$

Barleing sector

Gross NPLs

Monatly change (in peaceni)

Provistons in percent of gross NPL.

SDIF banks

Gross NPLs

Monthy change (in percent)

Provisions in percent of gross NPL

Non-SBIF banks

Gross NPLs

Monthly change (in percent)

Provisions in percent of grass NPL

Deporise 2y

Ratio of net NPLs to private sector credit $2 / 3 /$

Banking sector

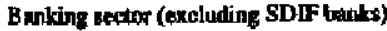

Rerda of privale vector crodit to ideposits $2 y$

Averise melurtity misnaxch 4

Banling sector
Herling vector (exclading SDIF bunks)

(In trilfiens of U.S. dolars, unless otherwise indicated)

\begin{tabular}{|c|c|c|c|c|c|c|c|c|c|c|c|c|c|c|c|c|}
\hline$-5,324$ & $-4,310$ & $-5,149$ & $-5,336$ & -803 & -242 & -766 & .724 & -695 & -880 & -695 & -129 & 11 & .192 & -67 & 271 & 561 \\
\hline 66.0 & 76.6 & 87,9 & 121.6 & 20.2 & 4.7 & 11.8 & 7.4 & 7.2 & 10.1 & 9.3 & 1.7 & -0.1 & 1.7 & 0.6 & 2.3 & 4.8 \\
\hline$-4,312$ & $-3,546$ & $-4,670$ & $-4,819$ & -645 & -559 & -844 & $-1,199$ & $-1,165$ & $-1,199$ & $-1,029$ & $\mathbf{4 4 1}$ & -365 & -648 & -656 & -85 & 106 \\
\hline 106.8 & 179.2 & 219.4 & 196.0 & 17.5 & 33.4 & 260.5 & 76.0 & 50.6 & 83.8 & -522.3 & -70.5 & 67.4 & 78.7 & 122.2 & 23.3 & 29.1 \\
\hline $\begin{array}{r}-1,012 \\
8.1\end{array}$ & -765 & -479 & -517 & -159 & 317 & 78 & 475 & 470 & 319 & 333 & $\begin{array}{l}312 \\
38\end{array}$ & 376 & $\begin{array}{l}4.56 \\
4.3\end{array}$ & $\begin{array}{r}589 \\
5.2\end{array}$ & $\begin{array}{r}356 \\
3.2\end{array}$ & $\begin{array}{l}456 \\
40\end{array}$ \\
\hline 8.1 & 10.1 & 6.0 & 7.6 & 2.1 & 4.7 & 1.1 & 5.8 & 6.4 & 4.4 & 4.3 & 3,8 & 4,1 & 4.3 & & $\mathbf{3 . 2}$ & 4.0 \\
\hline
\end{tabular}

\begin{tabular}{|c|c|c|c|c|c|c|c|c|c|c|c|c|c|c|c|}
\hline 3,566 & 3,897 & 4,270 & 4,978 & 5320 & 6.261 & 5,840 & 8.488 & 8,974 & 8,906 & 7,752 & 6,757 & 6,997 & 6,668 & 6,845 & 6,844 \\
\hline$\cdots$ & 9.3 & 9.6 & 16.6 & 6.9 & 17.7 & -6.7 & 45.3 & 5.7 & -0.8 & -13.0 & -12.8 & 3.6 & $-4,7$ & 27 & 0.0 \\
\hline 69.6 & 61.9 & 62.5 & 62.3 & 68,4 & 71.1 & 76.9 & 64.3 & 65.4 & 63.6 & 60.3 & 65.5 & 66.4 & 64.2 & 64.7 & 63.9 \\
\hline 1,576 & 1,825 & 1,917 & 1,987 & 2,119 & 2,794 & 3,040 & 3,610 & 3,913 & 3,650 & 2,561 & 989 & 987 & 966 & 915 & 688 \\
\hline & 15.8 & 5.1 & 3.6 & 6.7 & 31.9 & 8.8 & 18.8 & 8.4 & -6.7 & -29.8 & -61.4 & -0.2 & -2.1 & -5.3 & -24.8 \\
\hline 80.7 & 79.6 & 81.8 & 82.7 & 81.6 & 85.9 & 86.4 & 87.3 & 86.7 & 85.4 & 82.6 & 88.8 & 88.8 & 89.9 & 90.6 & 89.5 \\
\hline 1.990 & 2.073 & 2,353 & 2,991 & 3.201 & 3,467 & 2,800 & 4,878 & 5,061 & 5,257 & 5,192 & 5,767 & 6,010 & 5,702 & 3,931 & 6,157 \\
\hline ... & 4.2 & 13.5 & 27.1 & 7.0 & 8.3 & -19.2 & 74.2 & 3.7 & 3.9 & -1.2 & 11.1 & 4.2 & -5.1 & 4.0 & 3.8 \\
\hline 50.1 & 46.3 & 46.8 & 48.8 & 59.7 & 39.1 & 66.7 & 47.3 & 48.8 & 48,4 & 49.2 & 61.5 & 62.7 & 59.8 & 60.7 & 61.1 \\
\hline
\end{tabular}

$\begin{array}{lllllllllllllllll}57,051 & 63,063 & 71,518 & 74,697 & 75,248 & 83,605 & 85,412 & 91,844 & 100,012 & 104,429 & 101,862 & 103,768 & 100.102 & 101,184 & 192,111 & 104,157 & 105,016\end{array}$ (In percent)

Sources: Dala provided by the Central Bank of Thitry; the BRSA, and Fund staff estimateos.

1/ For May 2002, as of May 3.

2] For May 2002, as of Mry 10.

3 Net NPL are messured as eross NPLs mbevs provisions.

$4 /$ Average weightod motority of assers minus average weighted maturity of liabilities. 
Dear Mr. Köhler:

1. Turkey has kept up the determined implementation of the economic program. We met the end-March performance criterion for the consolidated government sector primary surplus and the end-April performance criteria for base money and net international reserves (Annex A). We have also continued to make progress in structural areas, including toward meeting prior actions and structural benchmarks (Annex B).

2. The program has continued to deliver positive results, increasing our confidence that both the 3 percent growth target and the 35 percent inflation target for 2002 will be met. Helped by our implementation of strict fiscal and monetary policies, structural reforms, and the increased credibility of the program, inflation outturns for the past several months have been favorable, leading to a steady decline in inflation expectations. As a result, we are now fully on track to meet our 35 percent end-year target. Real GNP in the fourth quarter of 2001 turned out weaker than expected, because of the negative impact of September 11 on expectations in Turkey and worldwide. Over the last few months, however, indicators have increasingly signaled the start of an economic recovery. Capacity utilization, industrial and agricultural production indicators, and the performance of exports and tourism in the first four months of 2002 all indicate that our target of 3 percent real GNP growth is attainable.

3. We remain determined to stay the course, recent uncertainties notwithstanding. Financial indicators improved substantially and beyond program projections in the six months to early May, but have since deteriorated somewhat, reflecting market perceptions of political uncertainty. We are confident that these disturbances will not derail our three-year program: interest rates are still markedly lower and the currency stronger than we envisaged at the start of the program; the strong balance of payments position and the favorable financial market conditions have allowed the Central Bank of Turkey (CBT) and the Treasury to boost both foreign exchange reserves and government deposits to well above the program assumptions; and the floating exchange rate and our efforts in banking, agriculture, and other structural areas have made Turkey's economy more robust than before. Broad support for the economic strategy from public opinion and civil society will facilitate its continued strong implementation, even if there were to be uncertainties in the political sphere. We remain fully committed to the economic program, which we believe is the best way of realizing Turkey's true growth potential and further increasing the resilience of the economy. At the same time, we stand ready to take additional measures if necessary to keep the program on track, in close consultation with the Fund. 
4. Against this background, we request that the second review under the stand-by arrangement be completed. Our targets and policies remain as set out in the January 18 Letter of Intent and its April 3 update. This letter further updates on policy developments, and describes additional steps we plan to take to achieve the program targets.

\section{Fiscal policy}

5. We remain on track to achleve our public sector primary surplus target of 6.5 percent of GNP in 2002. We met the end-March 2002 performance criterion on the consolidated government sector primary surplus, with higher-than-envisaged central government revenues offsetting a shortfall in state economic enterprise (SEE) performance, partly due to delayed price increases. To ensure that we continue to meet our fiscal targets, we will bring these prices back on track with program plans. In most cases these plans envisage increases during the year in line with annual WPI inflation, although in the energy sector we will continue to pass through world prices. We will also continue to audit SEEs on a quarterly basis to ensure that all cost-cutting and efficiency measures envisaged under the program are fully implemented. Looking forward, we will change the legal framework for SEEs, with effect from 2003, to help strengthen their governance structure, including by increasing the power of their Boards, clarifying their financial relationship with the government, and publishing details about their accounts.

6. For 2003 , we remain committed to maintaining the public sector primary surplus at 6.5 percent of GNP. With real interest rates declining and growth resuming, debt dynamics have improved further. We need to maintain the primary surplus to ensure further downward movement in interest rates and continued positive debt dynamics in 2003 . In the budget call, to be issued in June, we will take the first step toward achieving this fiscal stance. In particular, we will hold the overall ceiling for investment spending, the wage bill, and other current and transfer spending constant in real terms. Public sector wage policy will continue to be geared toward narrowing the difference between wages and civil servants' salaries.

\section{Monetary and exchange rate policies}

7. The main focus of monetary policy is the achievement of the inflation target. With all monetary performance criteria and indicative targets having been met in both February and April, inflation and interest rates have fallen sharply, bringing our end-year inflation target of 35 percent well within reach. We are making progress toward introducing formal inflation targeting later in the year, as planned. To this end, in cooperation with the Fund and with other central banks implementing inflation targeting, the CBT has been working intensively to develop: (i) economic databases and reporting packages; (ii) a nearterm forecasting system incorporating a wide range of available information; (iii) a core quarterly macroeconomic model; (iv) a process for putting together a medium-term projection; and (v) procedures for presenting the results to the Monetary Policy Council. 
8. Depending on the strength of the balance of payments and on reverse currency substitution, the CBT will continue to accumulate foreign exchange reserves through the daily auction mechanism. While adhering to the floating exchange rate regime and exchange rate policy as outlined in previous letters of intent, in April we introduced daily auctions to purchase foreign exchange, to boost our international reserve holdings. In the coming months, we will continue the daily purchase auctions to the extent the balance of payments remains stronger than expected.

9. We are making progress in improving the efficiency of the money and foreign exchange markets. In April, the CBT introduced one-month deposit auctions, which is helping to define the yield curve. Effective May 24, the CBT has lengthened the averaging period for banks' required reserves from one to two weeks, raised the proportion of reserve requirements that are subject to the longer averaging period, and linked the remumeration rate more closely to market interest rates. In addition, in mid-June parliament passed legislation that : (i) eliminates stamp duty on forward contracts, both foreign currency and Turkish lira denominated; (ii) reduces segmentation in the interbank market through extending the withholding tax for interest payments to Takasbank; and (iii) removes the tax on interbank foreign exchange transactions. These measures reduce intermediation costs in the financial system, and help reduce spreads and enhance bank profitability. We will continue to consult with all interested parties on measures to further develop these markets, including through further meetings of the multi-agency working group established in this area.

\section{Financial sector reform}

10. We are moving ahead with the strategy for recapitalizing private banks, with public support if needed. The original timetable for implementing the recapitalization scheme was intentionally ambitious, with the understanding that there might be some delays in implementation. After a slight delay in the completion of the first and second andits, on June 12, 2002 the Banking Supervision and Regulation Agency (BRSA) informed 24 banks (out of 26) of the amount of capital they need to raise. For these banks, the amount of capital shortfall has been estimated at TL 1,326 trillion, of which TL 1,102 has already been raised. As regards the remaining two banks (which shared the same owner), on June 19, 2002 the BRSA Board approved the takeover by the SDIF of the deeply insolvent medium-size one, and suspended shareholders' rights in the larger one, as the owner no longer legally qualifies as fit and proper for bank ownership. On June 19, the BRSA also sent a letter to the latter bank, which meets the capital requirements. With all these actions, we have met a prior action for completing the second review. The BRSA will hold a seminar later in June to inform banks, media, and market participants how the audit exercise was carried out, and the considerations BRSA made in determining banks' capital needs. Similar seminars will be held abroad in July. Banks are now expected to initiate the process of raising capital by calling shareholder meetings for no later than early July. Any public capital injections, which we expect to remain within the existing contingency, would take place soon thereafter. The BRSA expects the recapitalization to be completed by end-August 2002 , by which time the results of the recapitalization exercise will have been fully reflected in the banks' balance sheets. 
11. The SDIF is making progress in ensuring the transparency of its operations and resolving the remaining intervened banks. The external audit of the SDIF's accounts for end-2001 was completed on May 3, meeting a structural benchmark, and the SDIF has prepared monthly balance sheets starting end-March 2002 . The SDIF has published the audit results, together with monthly financial statements, on its website. Turning to the four remaining intervened banks, no acceptable bids were received for one of the banks (Toprak) by the April 9 deadline, but new bids have been invited by July 3. On the two banks under court proceedings, a ruling has been made about Tarisbank which was subsequently put up for sale on May 30, while a ruling on the other bank (Türk Ticaret) has yet to be made. The fourth bank (Bayindir) is acting as a bridge bank until a strategy has been developed for the resolution of assets of intervened banks that are being liquidated.

12. The SDIF is also working on a strategy for the resolution of assets in intervened banks, including through setting up an asset management company (AMC). The SDIF is exploring the options for establishing an $\mathrm{AMC}$, and discussions are being held to involve potential participants and investors, since the existing legislation limits the SDIF's ownership in an AMC to 20 percent. Work is also going on to identify assets held by the Collection Department suitable to be repackaged and sold or restructured. The BRSA will host a seminar on the possible use of an AMC for interested banks and market participants in June, with a final decision on creation of an AMC to be made in August.

\section{The implementation of International Accounting Standards is proceeding as} envisaged. The BRSA expects to publish the final regulation on its website in June (meeting a performance criterion for end-June 2002) to ensure that the new accounting standards are fully reflected in banks' balance sheets end-2002. In addition, by the end of the year the Treasury will send to the Council of Ministers a new draft law to regulate the insurance sector in line with applicable EU Insurance Directives and IAIS Core Principles.

14. The reform of state banks is proceeding apace. The operational restructuring of Ziraat and Halk is proceeding as envisaged, with 581 branches closed as of May 20, 2002, according to the criteria established by the Council of Ministers. Since potential investors in Vakif requested that the bank should be subject to the same audits as private banks under the recapitalization exercise, the privatization process for this bank has been slightly delayed. Potential investors were requested to submit bids by June 28 , and the winning bid is to be selected by July 14.

15. To complement the strengthening of the banking system and to support the real sector, we have launched the "Istanbul Approach" to encourage corporate debt restructuring. In early June, financial institutions signed a Framework Agreement which will be used as the basis for the debt workouts. In addition, the BRSA has approved regulations regarding provisioning requirements for restructured loans according to international best practices, to ensure the transparency and integrity of the bank recapitalization exercise. These regulations were issued in the Official Gazette on June 13. We are working closely with the World Bank in all areas of corporate debt restructuring, and have requested World Bank financing for a credit line to banks to provide additional long- 
term financing to corporates restructured under the Istanbul Approach. We hope that the credit line will become operational by year end.

16. Also in support of corporate debt restructuring, we are taking steps to improve bankruptcy and foreclosure procedures. The Ministry of Justice established a law reform commission in October 2001 to consider reforms to the Execution and Bankruptcy Act. This commission produced proposals at the beginning of 2002. In April 2002, the Ministry of Justice established another law reform commission focused on laws to support rehabilitation of viable firms in tandem with the out-of-court restructuring process. This latter commission will complete its work by end-June 2002 . Based on the work of the commissions, together with the recommendations of the forthcoming World Bank Report on Standards and Codes on Turkey's insolvency regime, the Ministry of Justice will produce by September 31, 2002 a package of comprehensive reforms of the Execution and Bankruptcy Act (a new structural benchmark). To ensure broad input into these important reforms, the Ministry of Justice proposals will be made available for comment by the public and private sectors. After this comment period, the proposed reforms will be submitted to parliament and enacted by endJanuary, 2003 (a new structural benchmark).

\section{Other structural reforms}

17. We are making progress with the overhaul of the tax system. On June 6, parliament enacted the Special Consumption Tax Law, meeting a structural benchmark. This Law consolidates various excises (including the two highest rates of VAT) and provides the Council of Ministers the power to set the earmarking of excise proceeds. To further streamline indirect taxation, by end-August the Council of Ministers will issue a decree setting the earmarking of excise proceeds at zero, starting with the 2003 budget, with commensurate appropriations made to the relevant agencies (a new structural benchmark). We have also designed a new functional structure for our tax administration, including an audit coordination unit, and a unit for tax policy. We expect to put this structure in place by end-July. Our work on direct tax reform and on an anmual audit plan has begun, and we expect to make rapid progress with the help of technical assistance which we have requested from the World Bank.

18. We are moving ahead with the rationalization of staffing in state economic enterprises and in other parts of the public sector. With the assistance of the High Auditing Board, we have completed a detailed accounting of redundancies in each state enterprise. A total of 45,800 positions have been identified as redundant as of end-January 2002. We remain committed to reducing two thirds of these positions by end-October 2002 and all of them by mid-2003. To accomplish this, we have agreed a protocol with unions, and issued an implementation circular indicating how these positions will be eliminated. The individuals occupying them will be (i) voluntarily retired, (ii) transferred to other open state economic enterprise positions, (iii) transferred to open civil service positions, or (iv) they will have their contracts ended. Any transfer of employees would be within the existing program cap for the hiring of new public and civil service workers, and subject to the individuals being qualified for the positions already identified in SEE and line ministry hiring 
plans. We have already begun to work toward our targets for reducing overstaffing. Between end-January and end-April, we eliminated 12,443 redundant positions (including individuals notified by end-January 2002), largely by voluntary retirement. We are also considering changing regulations on compulsory retirement to streamline the civil service.

\section{We are continuing our efforts to update Turkey's fiscal legislation and fiscal} management. On June 12, parliament approved several amendments to the Public Procurement Law, including reducing thresholds in real terms to international norms, and extending the minimum time period for procurement in cases falling below the thresholds (meeting prior actions for completing the second review). The amendments also aim to improve the operational and administrative efficiency of the procurement agency. We have also drafted a new budget systems law (the Public Financial Management and Internal Control Law) which extends accounting reforms, reorganizes internal audit, simplifies budget execution procedures, and broadens the coverage of the budget document to be presented to parliament for approval. We are currently revising this draft law, and will send it to parliament after consulting with the relevant domestic agencies and the World Bank, IMF, and EU.

20. We will advance the sale of key companies, building on the improved market conditions. The shallowness of the stock market has not allowed us to make the intended third public offering of TÜPRAS (petroleum refinery) in the second quarter of 2002 , as intended. However, we are exploring alternative strategies to lower the public share below 50 percent and will announce the chosen strategy by mid-July 2002. For the remainder of the year, the Privatization Agency has a portfolio of companies ready for tender, as outlined in the Agency's plan for 2002 issued last December. We expect that this, and the sale of assets outside the Agency's portfolio, will bring total privatization proceeds of US\$700 million in 2002. To underpin this target, we have set new indicative floors on cumulative cash privatization proceeds (Annex C). Moreover, by mid-July 2002 we will reduce the public share in ERDEMIR below 50 percent. The Agency is also achieving savings through merging companies in its portfolio. We estimate that the mergers already decided will generate operational savings of about US\$100 million annually.

21. We are also pressing ahead with the preparation for sale of other companies. A privatization road map for \$EKER has been submitted to the Privatization High Council for approval by mid-July. On June 4, the board of Türk Telekom (TT) approved a far-reaching corporatization plan for this company, prepared with the help of international consultants. This plan envisages the restructuring of TT into a holding company with subsidiaries organized around lines of business (such as basic infrastructure, fixed line services, and mobile services). Given that the corporatization plan is more ambitious and complex than originally envisaged, adoption of the privatization plan by the Council of Ministers (a prior action for completing the second review) has been delayed, but will take place by endNovember 2002 (a new structural benchmark). In support of this, on May 31, TT's Tender Committee approved a detailed road map of events leading to the adoption of the privatization plan. This road map envisages that (i) a new valuation for the company is established (in late May, the Council of Ministers already issued a decree cancelling the old 
valuation and facilitating a revaluation), (ii) international consultants for the revaluation and for developing the privatization plan are hired by end-August, and (iii) the

Telecommunications Law is amended by end-October 2002 to allow the sale of shares in the holding company and the subsidiaries. We expect that the holding company and the subsidiaries will be established by end-2002, allowing their privatization either separately or in combination.

22. Finally, we are taking additional steps to improve the business climate. On June 13, we submitted to parliament a new Law on Foreign Direct Investment (FDI), meeting a structural benchmark. This Law, which was drafted with technical assistance from the Foreign Investment Advisory Service, will provide a broad legal framework for FDI in line with international best practice. Among the significant improvements in the new Law is the removal of the minimum capital requirement and the approval condition for foreign investors. Details will be spelled out in implementing regulations. We have also established nine technical committees, each with private sector representation, under the Coordination Council for Improving the Investment Climate (CCIC) established by the Council of Ministers in December 2001. The technical committees are reviewing progress, identifying obstacles to investment, and proposing ways to remove these obstacles, with the aim of creating a more suitable climate for both local and foreign investment. The progress made by the CCIIC's technical committees and the prioritization of follow-up action will be discussed at the inaugural meeting of the high-level Investor Council on July 18. Other actions being taken to foster private business include reducing red tape in obtaining work permits and investment incentives, implementing an employee code of conduct for customs officials, and strengthening the Turkish Patent Institute. We are also improving the business climate through enhancing transparency in the use of public resources. To this end, on May 23 we appointed a Ministerial Steering Group and on June 11 a supporting subcommittee for implementation of our anti-corruption strategy, meeting a structural benchmark. This committee will now press ahead under the Ministerial Steering Group with the various initiatives envisaged under the action plan, including improvements in the public sector personnel system and enhanced public access to information about state organizations.

Very truly yours,

/s/

Kemal Dervis

Minister of State for Economic Affairs
$/ \mathrm{s} /$

Süreyya Serdengeçti

Governor of the Central Bank of Turkey 
Turkey: Quantitative Performance Criteria and Indicative Targets for 2002

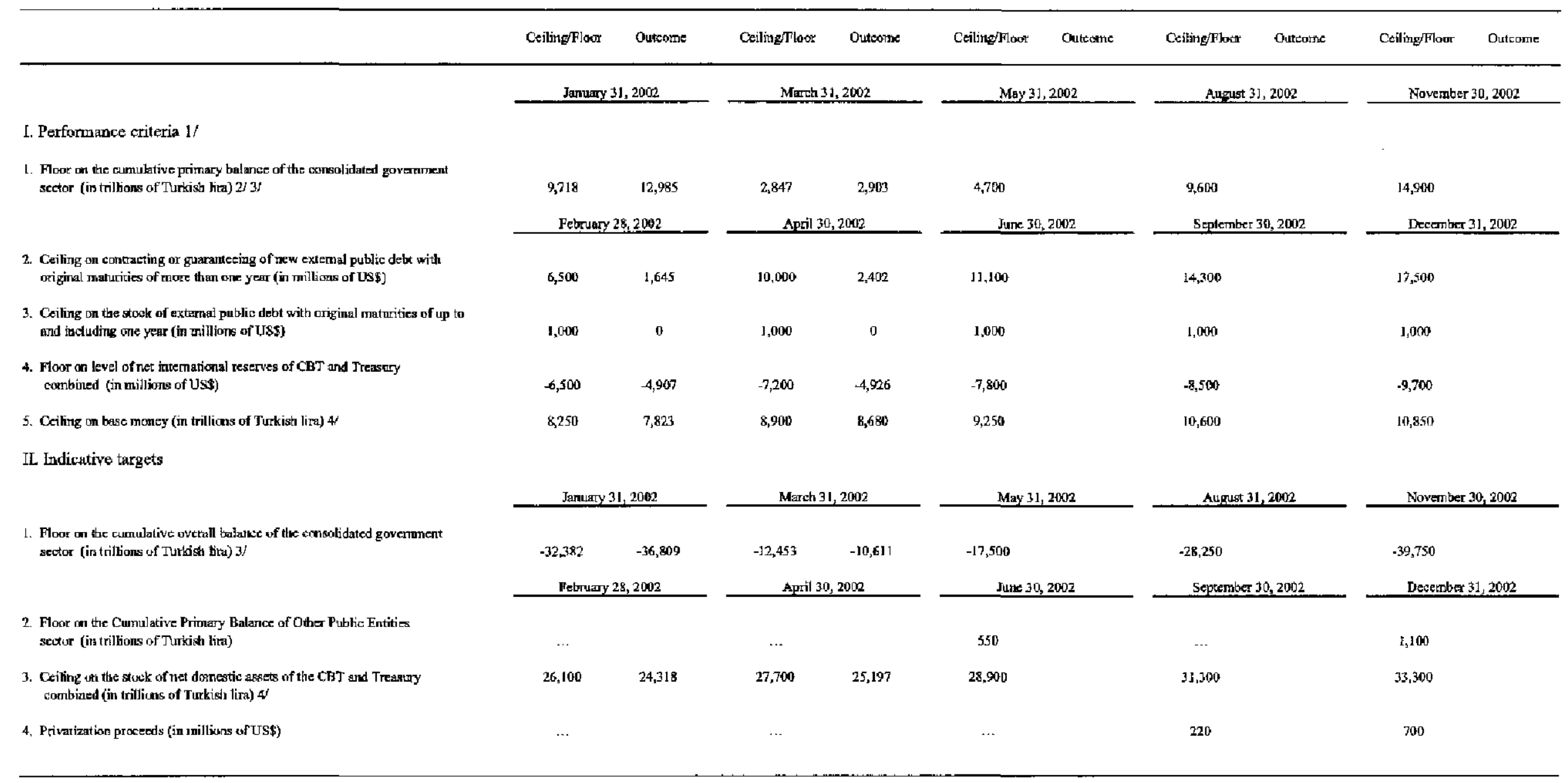

1/ The figures through June 30, 2002 are perfornence criteria. The ternaining figunes are indicative targets.

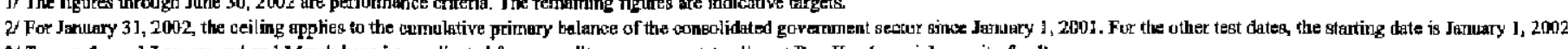

अ/Targets for end-Jartuary and ead-Mareh have been adjusted for expenditure arrears sutstanding at Bag-Kur (a sacial securrity fund).

4' Target calculated as four working day average of February I 1-12 and Maxch 1]-12, 2002, to take pccount of the transilory impacl of the Bayram religivus holiday or curtency demand. 
Structural Policies, 2002-04

\section{Action}

Type

LOI

Para $^{1 /}$

Status

June 19, 2002

\section{Fiscal policy}

1. Implement all further measures to reach the 6.5 percent primary surplus target that are technically feasible to put in place in January:

PA for 13

SBA

(i) Council of Ministers to approve a reduction in the share of central government tax revenues accruing to metropolitan municipalities to 4.1 percent

(ii) issue a circular to implement attrition rules

(iii) the Minister of Finance to approve a reallocation of spending to ensure adequate funding for DIS for agriculture

2. Increase the PCT (on items excluding natural gas) by 1 percent in real terms in early February

3. By end-March (i) the Ministry of Finance to identify savings from closing regional administrations and other regional line agency offices, and block relevant budget appropriations in the budget, and (ii) SEEs to approve budgets in line with the cost reductions mandated

4. Keep investment expenditure in SSK at the level originally planned in the investment program for 2002 , implement generic drug purchase program in ES by end-April, and receive profit transfer of TL 180 trillion from Ziraat Bank

5. Refrain from introducing any new tax exemptions or incentives, except those specified in the tax reform plan

5 of April Not fully complied with. SSK's 2002 LOI investment is not expected to fall, since several of its projects fall outside of the annual investment program and are not subject to the limits therein. The Ministry of Health now aims to finalize the generic drug purchase program by end-2002. The profit transfer from Ziraat was received in April 2002.

Not fully complied with. Payroll and personal income tax deferments were introduced in March 2002 as part of an effort to stimulate employment. 


\section{Action}

6. Refrain from introducing any new discounts or exemptions for SEEs, except those pursued for commercial reasons by enterprises'

managements

7. Change the legal framework for SEEs, with effect from 2003, to help strengthen their governance structure, including by increasing the power of their Boards, clarifying their financial relationship with the government, and publishing details about their accounts.

\section{Public debt management}

8. Continue to lengthen average maturity in Treasury bill auctions and public offerings to the extent demand allows and encourage a diverse range of investors

9. Resume in January 2002 the program of FRN auctions. Before the first issue publicize a revised standard method of price and yield calculations, in line with international practice

10. Reintroduce a primary dealer program by end-September 2002

11. Continue to issue, subject to market conditions, domestic FX denominated and $\mathrm{FX}$ indexed bonds, as well as international bonds

12. The Treasury to complete a study by end-June 2002 of its operational mechanisms, procedures, and structure to improve its risk and debt management, including through closer coordination between domestic and international borrowing. The recommendations of this study will be implemented during 2002

13. Issue in June government communique that spells out details of the operations of the middie office that will formulate overall public debt strategy

\section{Type LOI Status} June 19, 2002
Done, but partially reversed. The president approved Law No:4736 on January 18, 2002 preventing any new discounts or exemptions for SEEs. However, discounts for electricity were reintroduced in May, for phase out by end-2002.

5 of June

2002

LOI
Being implemented.

Done.

Discussions with candidate primary dealers are taking place.

Taking into account redemptions and market conditions, FX denominated and FX indexed securities will be issued.

As an interim step the new Debt Management Law calls for the establishment of a middle office in the Treasury in charge of developing the overall debt strategy and managing risk. A worksbop with the participation of international experts was held in May 2002 in cooperation with the World Bank, and will provide the basis for the study.

6 of April General strategy is expected to be 2002 LOI determined in June. 


\section{Action}

14. The Treasury to develop its cash management operations, acting in coordination with the CBT

15. The Treasury to intensify its dialogue with the full range of investors, including bilateral contacts and group discussions with institutional investors and intermediaries, and enhanced retail outreach

\section{Monetary and incomes policy}

16. Ensure that any new laws or regulations do not undermine the independence enshrined in the CBT law

17. CBT to continue its technical preparations for the introduction of inflation targeting including improved modeling and forecasting of inflation

18. Move to inflation targeting

19. Seek a significant reduction of the ex-post indexation element contained in current wage contracts during the next public worker collective bargaining round and civil service salary adjustment, and use the Economic and Social Council as a forum for incomes policy discussions with the private sector

20. a. Consider the possibility of reducing backward indexation of administered prices without compromising SEEs' financial conditions

19

(1)

Type LOI

\section{$\operatorname{Para}^{1 /}$} 19

(1)

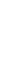


b. In the ongoing negotiations on new two-year private sector wage contracts the government to stress to labor unions and employers the need to reduce backward indexation

21. Encourage a successful conclusion by end-February 2002 of banks' discussions to establish interbank borrowing reference rates in Turkish lira out to at least three-month maturity to enhance money market liquidity and transparency, and to provide accurate reference rates for financial instruments

22. The CBT to gradually end its practice of acting as a blind broker during 2002

23. Working group to facilitate the development of financial markets to identify concrete actions by end-January 2002 in the areas of taxation, accounting, and regulation. The first measures will be put in place by end-February 2002

24. The Privatization Agency to authorize companies in its portfolio to transact their foreign exchange business at the market rate (not at the CBT official rate). The oil and gas comparies (TÜPRAŞ and BOTAŞ) to work with state banks to improve their foreign exchange practices, to minimize lumpy transactions in the foreign exchange market

25. To encourage development of the foreign currency market, eliminate stamp duties on forward contracts and remove the tax on interbank foreign exchange transactions by end May 2002

26. Require as of end-May withbolding of interest earned through transactions intermediated through Takasbank

27. To rationalize the system of reserve requirements the CBT, effective from May 2002, to (j) increase the scope and length of the averaging of reserve requirements, and (ii) increase the remunetation of both Turkish lira and foreign currency reserves, linking remuneration to market rates
14 of

April

2002

LOI

25

25

9 of April

2002 LOI

9 of April

2002 LOI

9 of April

2002 LOI
A working group established under coordination of the Banks Association is discussing proposals, and measures are being intraduced to deepen the interbank money market.

The phasing out by end-2002 has been announced by the CBT.

Interagency committee chaired by CBT with membership from Banks Association of Turkey, BRSA, MOF and ISE, established and has held two meetings. Taxation of revaluation profits clarified in February, and prudential rules on market risks effective since January 2002.

Done.

Done.

Done.

Done. 
28. Multi-agency working group to continue to identify measures to ensure the successful development of money and foreign exchange markets
9 of April 2002 LOI
Multi-agency working group chaired by the CBT with the participation of Banks Association of Turkey, BRSA, MOF, ISE, IGE, Treasury, and CMB has held meetings related to the development of the derivatives markets and TL reference rate fixing. Taxation and accounting problems of the futures transactions have been solved by the MOF and BRSA, respectively.

\section{Banking reform}

29. Pass necessary legal amendments, and issue a Council of Ministers Decree for staff reductions in state banks

30. By end-June 2002, reduce the number of state bank branches by 800 . In this context also reduce staffing correspondingly

31. For Vakif Bank privatization, bids to be invited from potential investors in May

32. BRSA to issue guidelines for targeted evaluations of private banks in preparation for the public support scheme for private banks

33. The targeted evaluation of loan portfolios, collaterals, and certain other exposures to be performed by banks' existing external auditors to be completed by end-March

34. Third-party auditing firms to be appointed by the BRSA by endMarch 2002 to verify that the guidelines have been followed, and to ensure the integrity of the process

35. a. The BRSA to (i) complete the final interpretation of the evaluations by end-April and (ii) send letters to banks stipulating required actions on the basis of this interpretation by May 15

\section{PA for \\ SBA.}

PC

PA for SBA

BM

PA for second review (action \# (ii))
Done.

640 branches of state banks have been closed and staff reduced by 12,000

Four potential bidders have expressed interest and are conducting due diligence; potential bidders are waiting for the audit results being carried out under the new public support scheme. Bids are expected by end-June, and privatization is expected to be completed in mid-July.

Done.

Done.

30,31

a. Done. (i) Auditing reports submitted to the BRSA by late May

(ii) Letters to 24 banks sent on June 12 . Of the remaining two banks, one was intervened on June 19 , and a letter was sent to the other bank the same day. 
b. Evaluation results to be fully incorporated into banks' end-June 2002 financial statements

c. Banks to apply for participation in the scheme before end-May 2002

d. Recapitalization scheme to be completed before end-June 2002

e. The BRSA to prepare prototype contracts to be signed between the Saving Deposit Insurance Fund (SDIF) and the majority shareholders on the pledging of shares, share buy-backs, and the conversion of Tier-2 capital into Tier-1 capital

36. The legal framework and related regulations for the public support scheme for private banks to become effective in January 2002

37. The BRSA to undertake legal consultations, as necessary, to ensure implementation of the public capital support scheme as planned

38. Resolve by end-2001 all banks taken over by the SDIF before November 2001, with the exception of two banks whose resolution has been halted by courts

39. Determine final resolution method for the medium-size bank taken over in November 2001 by February 2002

40. The SDIF to prepare a monthly balance sheet starting end-March 2002 and become subject to annual external audits; the external audit for 2001 will be completed by end-April 2002

41. Laws and regulations regarding loan classification, loan loss provisioning, and collateral valuation will be amended as necessary following the portfolio reviews by end-June 2002

42. Pass legal amendment in January 2002 to eliminate with immediate effect the existing four-year transition rule for loan loss provisioning

43. Start trial implementation of new accounting system (for banks) in line with IAS in January 2002

44. Following the trial implementation the BRSA to evaluate the experience and issue by end-June 2002 a revised regulation on the new accounting standards to ensure that banks' end-2002 balance sheets comply with IAS b. Evaluation results expected to be incorporated by end-August 2002.

c. Banks expected to apply by July 5, 2002.

d. Cormpletion expected by endAugust 2002.

10 of e. Done.

April

2002 LOI

PA for

32

SBA

32

Done.

PA for

SBA

Done. After no acceptable bids were received by the original sale deadline of April 9, the bank was reoffered for sale in mid-May. The new deadline for bids is July 3. Two potential buyers are performing due diligence.

BM (the 34 Done.

latter action)

Done.

PA for

SBA

PA for

35

SBA

PC for 35 end-June
Done.

Done.

Underway. 
45. Improve reporting requirements based on the findings of the independent assessments, and strictly enforce the quality and timeliness of the reporting as of end-June 2002

46. a. Off-balance sheet repos to be included on balance sheet as of February 1, 2002

b. Capital charges for market risks to be calculated on a solo basis as of January 1, 2002 and on a consolidated basis as of July 1, 2002

c. Regulation on monitoring of internal control and risk management systems to become effective January 1,2002

47. By end-2002 the Treasury to send to the Council of Ministers a new draft law to regulate the insurance sector in line with the applicable EU Insurance Directives and LAIS Core Principles

\section{Corporate debt restructuring}

48. Introduce in January 2002 a voluntary market-based framework (the "Istanbul Approach") for dealing case-by-case with multicreditor exposures to large and medium-size borrowers

49. Create in early 2002 a multiagency Coordination Committee with private sector participation under the Treasury, responsible for facilitating and monitoring the corporate debt restructuring process, as well as identifying and proposing the removal of impediments that may exist

50. Establish secretariat to the Production and Finance Committee in April

51. Production and Finance Committee to develop further measures consistent with preserving the transparency and integrity of the bank recapitalization exercise, to catalyze banks' and corporates' participation in the "Istanbul Approach"

52. Production and Finance Committee to work with the relevant government agencies to establish by June 2002 a database to monitor corporate debt

53. A private asset management company will be set up by end-August 2002, with the SDIF owning a minority share
35

35

13 of June

2002 LOI
Underway. Quality and timeliness of reporting expected to be improved as of end-August 2002.

Done.
36; 13 of April 2002 LOI

13 of April 2002 LOI

13 of April 2002 LOI

13 of April $2002 \mathrm{LOH}$

13 of April 2002 LOI
Done.

Not done. Work to be carried out by the Production and Finance Committee chaired by the Treasury.

Although the Committee has not been established yet, the BRSA is coordinating the process.

Although the Committee has not been cstablished yet, the BRSA is coordinating the process.

The CMB has issued the regulation on the reporting requirements. Firms are expected to start reporting in June 2002.

The authorities have requested technical assistance for the drafting of a proposal for potential investors. 
54. a. The Ministry of Justice to prepare an action plan based on the findings of a World Bank Report on Standards and Codes (ROSC) on Turkey's insolvency regime and form a Commission to prepare necessary amendments to the Bankruptcy Law

b. The Ministry of Justice to produce a package of comprehensive reforms of the Execution and Bankruptcy Act by September 31, 2002

c. Enactment of the reforms of the Execution and Bankruptcy Act by end-January 2003

55. Support the upgrading of administrative procedures in the judiciary to improve the capacity of the courts

56. The CMB to introduce international accounting standards, including inflation accounting provisions, by January 1, 2003.

57. Starting end-March 2002, the CMB to require corporate groups to provide consolidated financial statements and to set up a dedicated group to monitor their finances

58. Starting end-March 2002, the CMB to require corporate groups with financial affiliates to provide consolidated group statements and share those statements with the BRSA

\section{Public sector reform}

59. Parliament to approve Public Procurement Law in line with UN (UNCITRAL) standards in January 2002

60. Establish an independent procurement agency by end-March 2002

61. Change laws and regulations to make them consistent with the new public proeurement framework

62. Parliament to amend the Public Procurement Law by end-May 2002, to (i) bring the real value of the thresholds toward those in line with international best practice and (ii) extend the minimum time period for procurement applicable for cases below the thresholds
37

$\begin{array}{ll}\text { BM } & \begin{array}{l}16 \text { of June } \\ \text { LOI }\end{array} \\ \text { BM } & 16 \text { of June } \\ & \text { LOI }\end{array}$

37

38

PA for

SBA

$\mathrm{BM}$

PA for second review
A commission to prepare necessary amendments to the Bankruptcy Law has been established. Draft World Bank report received in May. 


\section{Action}

Type

LOI

Status

Para $^{\mathrm{IJ}}$

June 19, 2002

63. Compile a comprehensive list of public investment projects to be phased out in time to make decisions for the 2003 budget

64. Approval by Council of Ministers in January 2002 of plan to reform the tax system

65. a. Enact the first phase of the tax reform plan by end-April 2002

b. Issue a decree by end-August 2002 setting the earmarking of SCT proceeds at zero, starting with the 2003 budget

66. Submit to parliament legislation for the second phase of the tax reform plan by end-October 2002

67. Reorganize tax administration in line with the study carried out with the World Bank:

a. By end-July, institute an audit coordination unit in the Ministry of Finance, and require that it produce a coordinated andit plan by endNovember each year

b. By end-September, the Minister of Finance to adopt a strategy to strengthen the collection of outstanding public sector tax arrears

c. In the budget for 2003 , include resources to increase the number of auditors by 400 (for October 17) to move toward OECD standards

d. To help overhaul the revenue administration in the medium term, implement a functional reorganization, beginning at end-June

68. Council of Ministers to adopt a civil service reform strategy by end2002

69. As part of the preparatory work for $\$ 68$, by end-March 2002 establish a ministerial committee to carry out a functional review of goverument, which will be completed by end-September 2002
40

PA for

SBA

BM

$\mathrm{BM}$

$\mathrm{BM}$

BM

(first such

plan by

Nov 2002)

BM

BM
Rationalization of public investment program will continus in 2003 within the framework of a High Planning Council Decision. The Decision will be communicated to spending agencies with 2003 Investment Circular in June 2002. Then the list will be compiled concurrently with 2003 investment programming process that will be finalized by end-2002

Done.

40 Done.

$40 ; 15$ of April 2002 LOI

17 of June

LOI

40

40 and 15 of April 2002 LOF
Done. Special Consumption Tax Law (implementing indirect tax changes) was approved by parliament on June 6 .

A World Bank technical assistance mission is expected in July.

Underway. The GDR has designed a new functional structure that includes a tax audit coordination unit. However, some work remains to fully flesh out the details, and an internal audit unit will need to be added.
40

40
Done. CoM decision dated February 4, 2002 has been issued. 
70. By end-September, have in place an integrated system to monitor total general government and SEE employment levels on a quarterly basis

71. 15,000 individuals (public sector workers) to have been retired or notified of their retirement by mid-January 2002

72. By end-January 2002,

(i) identify all redundant workers and positions in SEEs

(ii) sharpen tentative estimate based on aggregate analysis, by using company-specific information and by end-May produce final estimates

(iii) eliminate all open, unfilled redundant positions

73. Extend voluntary retirement offers to the recently identified redundant workers in Türk Telekom and in the Privatization Agency portfolio of companies; for those who accept, provide payments, and allow them to retire, no later than end-March 2002

74. Through voluntary retirement offers, and layoffs only when necessary, reduce the number of redundant workers by one-third by endJune, and cumulatively by two-thirds by end-October 2002

75. By end-June 2003, phase out the remaining redundancies

76. The Ministry of Finance and the Treasury to formulate by endSeptember 2002 an action plan to address redundancies in the central government

77. Audit SEE compliance with this program on a quarterly basis

78. To strengthen the legal framework for fiscal policy pass the Law on Public Debt Management and issue two supporting communiqués

41

41

PAs for 42
Type

$\mathrm{BM}$

40

PA for 41 Done.

SBA

LOI
Para $^{1 \prime}$

Status

June 19, 2002

PAs for

first

review (i) 41

and (iii)

15 of

April

2002 LOI

41 Done.

41

Underway. The retirement offer remains open.

PC (the 41

Oct

action)

Underway. As of end-April, 12,443 redundant positions had been eliminated (including SEEs; monitoring of SEE employment levels has started on a quarterly basis as of March. positions have been determined as redundant in SEEs.
A circular (dated December 14,

(i-ii) Done. A total of 45,800 individuals notified of their impending retirement as part of the prior action for the program-see item 71).

15 of

April

2002 LOI

Underway. The modalities of extending the staff reduction program to the civil service are under consideration.

Underway. Treasury Controllers audited all SEEs (except Türk Telekom) in April-May.

Done.

the first review 
79. Submit to parliament by end-June 2002 a Law on Financial Management and Internal Control consistent with best international practices

80. Close, by end-March 2002, 548 additional revolving funds

81. Incorporate in the draft budget for 2003 the revenue and expenditures under Law 3418

\section{Eliminate the earmarking under Law 3418 and Law 4306}

83. Amend by July 2002 the governing legislation for the remaining EBFs to require passage of their budgets by parliament, external audit of their accounts (reported to parliament), and monthly reporting of their accounts, on a consolictated basis, with the central government's accounts

84. Eliminate the remaining budgetary fund (the Support Price and Stabilization Fund) in three years, when the World Bank's Agricultural Reform Implementation Project ends

85. In the draft 2003 budget to be submitted to parliament (i) include net lending as an appropriation, and (ii) extend accounting and coding reforms to all consolidated budget agencies, and to general govemment units on a pilot basis

86. Complete, by end-March 2002, a survey of end-2001 commitments in excess of appropriations

87. To monitor and address [expenditure] commitments on a regular and timely basis, conduct surveys of commitments in excess of appropriations twice a year (as of end-June and end-December), with the aim of having the results available within six weeks after the end of each period

88. Address the impact of public sector retrenchment through the labor redeployment and reinsertion program and through unemployment insurance
BM

42

BM

42

BM for

Oct 17, 2002)

BM

42

42

BMs for

42

Oct 17, 2002)

BM

42

15 of

April

2002 LOI
$A$ draft law has been prepared and will be provided to IFIs and the EU for comments in June. To be submitted to the parliament subsequently.

Done.

To be handled in the context of the Law on Financial Management and Internal Control.
To extend coding reforms to general government units on a pilot basis, the MoF has prepared a budget implementation circular. Studies regarding accounting reform are progressing as planned.

Done.
As per the circular (No.1087, $2002 / 3$ ) issued on January 21, 2002, services for counseling and training have started to be tendered. Unemployment insurance payments started in March 2002. 


\section{Enhancing the role of the private sector}

89. The Privatization Administration (PA) to proceed with the public offerings of POAS by end-March 2002 and the public offering of TÜPRAŞ by end-June 2002 and launch the initial public offering for THY as soon as market conditions allow

90. a. CoM to adopt a privatization plan for Türk Telekom in April 2002

b. CoM to adopt a privatization plan for Titrk Telekom by endNovember 2002

91. Parliamentary approval of Tobacco Law

92. Prepare and adopt a privatization plan for TEKEL by end-September

93. Proceed with the privatization of SEKER, with the first step being the adoption of a privatization plan by May 2002

94. a. In the electricity sector, in January 2002 , subject to legal clarification, the Council of Ministers to adopt a government decree annulling with immediate effect all the projects for which transfer of operating rights (TOOR) contracts are pending

b. Following the Constitutional Court decision regarding the pending transfer of operating rights (TOOR) contracts, determine which, if any, investors are eligible for Treasury guarantees and inform by end-June 2002 those eligible of the amendments needed to bring the contracts in compliance with the license regulations of the Energy Market Regulation Agency and the Electricity Markets Law. With the exception of these eligible projects, transfer all state-owned thermal generation and electricity distribution assets under the scope of privatization by end-July 2002. Moreover, the eligible contracts for which the financial arrangements have not been finalized by end-January 2003 will be cancelled, and the related assets transferred under the scope of privatization by end-February 2003
PA for the

second

review

BM

PA for

SBA

PA for

fourth

review

45

45

21 of June

I.OI

45

45

45

The second public offering of POAŞ was completed in March 2002 with a 16.5 percent stake sold to foreign and domestic investors, New privatization strategy will be determined for TÜPRAŞ by midJuly 2002. The privatization of THY depends on market conditions.

Not met because of change in strategy. The corporatization plan approved on June 4, 2002 requires a more complex privatization strategy than originally envisaged. Deadline changed to endNovember.

Dane.

A restruaturing study is being undertaken to provide a basis for the privatization plan.

A privatization road map for SEKER has been submitted to the Privatization High Council for approval by mid-July.

Changed. See item $b$.
16 of

April

2002 LOI 
95. By March 2002, the Ministry of Energy to inform the PA which electricity assets will be privatized, and by April 2002 the prequalification tenders for the distribution companies will be launched

96. Complete the transfer of gas distribution companies to the PA by March 2002

97. The PA to go forward with the divesting of ETI Krom AS, ETI Elektrometalurji AȘ, ETI Gümiüs AŞ, which are in the $P$ A portfolio, as soon as licenses are transferted from ETI Holdings

98. The PA to continue its divestment of ERDEMIR, and of tourism and fertilizer assets in its portfolio. The PA also to continue divesting its portfolio of small and medium-size companies

99. Build on efforts made in 2001 (including legal amendments and simplified procedures) to increase the sale of government land. Initiate a study to evaluate how the remairing obstacles to government land sales could best be removed

100. The Council of Ministers to adopt in January 2002 follow-up actions to FIAS study to make Turkey more attractive for domestic and foreign investors

101. Submit to the parliament by end-May 2002 a new draft Law on Foreign Direct Investment in line with the findings of the FIAS study

102. Submit to the parliament by end-March 2002 a draft law on work permits prepared by Ministry of Labor and Social Security, and issue a communiqué by end-April 2002 on the implementation procedures for employing foreign personnel employed by foreign capital companies as soon as the new law is approved by parliament

103. Complete by end-February 2002 legislation reducing the number of documents needed to obtain investment incentives

104. Establish and implement by end-February 2002 an employee code of ethical conduct for proceedings at customs

105. Submit to the Council of Ministers by end-January 2002 legal amendments to strengthen the Turkish Patent Institute

Changed. See item 94 above.

High Planuning Council Decision is about to be finalized after which a Privatization High Council Decision will be sought.

A High Privatization Council decision (No: 2002/29) was issued on April 30, 2002 for the transfer of licenses of ETI Krom AŞ, ETI Elektrometalurji A.Ş., ETI Gưmus A.S., ETI Baktr A.Ș. to these companies from ETÍ Holding.

\section{Preparations underway.}

PA for

SBA

BM

\section{Done.}

Dane. Law submitted to parliament on June 14.

A draft law on work permits has been submitted to parliament and is currently with the relevant commission.

Done.

Being inplemented. A communiqué was issued on September 11, 2001.

Draft law has been submitted to the Prime Ministry and is expected to be submitted to CoM for signatures soon. 
Action

Type
Para $^{11}$

Status

June 19, 2002

106. The Council of Ministers to adopt a strategy by end-January 2002

for increasing transparency and combating rent-seeking activitics

107. Define and include as program conditionality concrete follow-up actions for the remainder of the 2002-04 program period based on the plan in \#106:

a. Establish by end-April 2002 a Steering Group for public sector reform, as well as a subcommittee to provide support to the Steering Group in implementing the plan to enhance transparency and good governance

b. Publish (i) the above-mentioned action plan to enhance transparency and good governance, and (ii) the Report on the Observance of Standards and Codes (ROSC) on the quality of economic data, carried out in consultation with the IMF

c. Improve the public sector personnel system, including passage of legislation to establish a code of ethical conduct for civil servants and public administrators by end-2002

d. Increase access to information, through the preparation of an Information Act, defining the rights of citizens to request information and the obligation of public organizations to provide information by end2002

108. Establish an Investor Relations Office by February

109. Establish an Investor Council consisting of prominent business representatives from Turkey and abroad

110. Further strengthen the efforts of the Treasury, the CBT, and the BRSA to explain policies under the economic program in their respective areas, including through the arrangement of regular (bimonthly) press conferences by the Treasury

\section{Safeguards Assessment}

111. Follow-up measures in the context of Safeguards Assessment:

a. With effect from 2001 financial statements the CBT to publish audited financial statements consistent with IAS

b. Starting with the 2002 financial statements, the CBT to clarify disclosures of the Fund position and the relationship with the Treasury, and limit the amount of profits available for distribution to realized. profit, less unrealized losses
BM 47 13

47 and 18 Done.

of April

2002 LOI

BM

BM
48

48

48

19 of

April

2002 LOI Done

Done.
Done

Done.

Done. Decree signed on February 13

Inaugural meeting scheduled for July 18

Ongoing

\section{Ongoing}


c. CBT to expand the role of its existing audit committee

d. Include among the duties of the external auditor to issue a report reviewing the consistency between program data reported to the IMF (specifically covering base money, net international reserves, and net domestic assets) and the audited financial statements

e. By May 15, 2002 the CBT to ask the existing audit firm to prepare such a report, to be issued by July 15, 2002

$f_{*}$ By May 15, 2002, the CBT to issue a Memorandum of Understanding to clanify the Treasury/CBT relationship with the Fund.

g. The CBT to reorganize by end-2002 the internal audit function. To this end, it will (i) adopt a new charter, which will detail the mission, scope, accountability, independence, responsibility, and authority of the audit function in line with the Standards for the Professional Practice of Internal Auditing of the Institute of Internal Auditors, and (ii) formulate an implementation plan identifying staffing levels, reporting lines, scope of audits, risk assessment methodologies, and developing an intemal audit manual and training programs

i. Internal audit department to conduct an audit of foreign exchange management and program data as of end-2002 by May 15,2003
The Audit Committee will meet twice a year with the external audit firm and, once established, with the internal audit department. It will also review the CBT's overall risk management practices and systems of internal control.

Done

PC

(issuance

of report)

PC

(measure

(i) and

(ii))

M
Done. Memorandum of Understanding was signed between Treasury and CBT on May 6 , 2002.

1/ Unless otherwise noted, paragraph numbers refer to January 18, 2002 Letter of Intent. 
Tabte 1. Turkey: Indicative Target on Cumulative Privatization Proceeds of the Consolidated Government Sector

\begin{tabular}{lc}
\hline & $\begin{array}{c}\text { Floor } \\
\text { (In millions of U.S. dollars) }\end{array}$ \\
\hline Cumulative privatization proceeds from January 1, 2002, to: & \\
September 30, 2002 & 220 \\
December 31, 2002 & 700 \\
\hline
\end{tabular}

1. The consolidated government sector is defined in Annex D of the January 18, 2002 Letter of Intent for the Stand-by Arrangement.

2. Privatization proceeds are measured in cash terms, except in the case of conversion of an exchangeable bond (proceeds exclude amounts realized from the sale of convertible bonds).

3. Privatization proceeds exclude sales of immovables and movables, and any other items already captured in the performance criteria for the consolidated public sector (see Annex D, referenced above).

4. Privatization proceeds exclude any sale of assets to entities in the consolidated government sector, to the local governments, or to state economic enterprises not captured in the program definition of the consolidated government sector.

5. Privatization proceeds exclude receipts from the sale of transfer of operating rights (TOORs). 
1. This statement provides an update on economic and policy developments since the staff report (EBS/02/109, 6/20/02) was issued. The new information does not change the thrust of the staff appraisal, but underscores two of its key messages: (i) vulnerabilities remain, calling for an unwavering commitment to the program; and (ii) for the authorities' efforts to be fully successful, lessening market concerns about domestic political uncertainty will be critical.

2. Latest indicators continue to suggest that the macroeconomic objectives for 2002 remain within reach. Both exports and imports showed strong performance in April (seasonally adjusted monthly increases of 15 and 24 percent, respectively), confirning a pick-up in activity. Capacity utilization remained unchanged in May on a seasonally adjusted basis, but was up by 5 percentage points from a year earlier. The CBT's most recent survey shows a slight increase in the mean inflation expectation for the end of the year to 35.6 percent, still close to the 35 percent end-year target.

3. Market indicators have, however, weakened further over the past week. The impact of fayorable news-including completion of the prior actions and the announcement of the Board date- has been more than offset by continued political uncertainty, market concerns about the implications of the bank audit results, and contagion from weak global markets and Brazil. Since June 19, the interest rate on the benchmark bond has risen 5 percentage points to 75 percent, the Turkish lira has depreciated by $2 \frac{1 / 2}{2}$ percent against the U.S. dollar, stock prices have fallen by 4 percent, and the spread on Turkish Eurobonds has widened by another 100 basis points. On June 26, Standard and Poor's lowered the outlook to stable from positive on its B-- sovereign rating for Turkey.

4. The authorities have followed up on the private bank audit and recapitalization exercise. As noted in Box 4 in the staff report, the targeted assessments (based on two audits) showed the level of nonperforming loans (NPLs) in 26 privately owned banks to be 16 percent of total loans at end-2001, compared with the earlier reported 5 percent. The NPL estimate has now been updated to reflect two developments. First, the intervened Pamuk bank has been excluded, leaving 25 banks to be covered. Second, given uncertainties about the financial condition of the common shareholder in Pamuk and Yapi Kredi, the BRSA decided that out of prudential caution Yapi Kredi needed to classify all its connected loans as doubtful and make provisions (net of collateral) equal to 50 percent of the outstanding amount of connected loans. These two changes raised the NPL ratio for private banks to 25 percent. Even with the increased provisioning requirements, Yapi Kredi's capital adequacy ratio is 10.2 percent.

5. Further progress has been made in meeting structural conditionality in banking. On June 22, the BRSA issued a revised regulation on the new accounting standards to ensure that banks' end-2002 balance sheets comply with IAS, meeting an end-June structural performance criterion. Considerable progress has also been made toward meeting the endJune structural performance criterion on reducing the number of state bank branches by 800 . 
With 80 branches closed between April 4, 2001 (when the restructuring of state banks started) and end-2001 and 679 more closed through June 25 this year, the authorities will, however, likely miss the performance criterion by a small margin. The staff will follow up on branch closures in the context of the third program review.

6. End-June monetary targets are likely to be met. By all indications, the performance criterion on net international reserves and the indicative target on net domestic assets will be observed with considerable margins. The authorities report, however, that the performance criterion on base money is likely to be met by only a small margin, since currency demand has been higher than anticipated, both because of stronger than usual seasonal factors (in agriculture and tourism) and the effects of the intervention in Pamuk bank. The staff will monitor developments and seek continued compliance with the monetary targets in the context of the third review.

7. The authorities have also taken measures to keep fiscal policy on track. Between late May and June 26, the authorities raised sugar prices by 4 percent, natural gas prices by 8 percent, and prices for alcohol, tobacco, tea, and pulp and paper by $10-15$ percent. The staff estimates that these measures have a direct impact of about $1 / 2$ percent on the CPI, and that they close about one third of the full-year fiscal gap of $1 / 2$ percent of GNP. Increases in telecommunication charges, which would close the bulk of the remaining gap, are expected shortly. Further increases in alcohol, tobacco, and sugar prices are scheduled for September.

8. The staff supports the authorities' request to waive the applicability of the endMay performance criterion on the cumulative primary balance of the consolidated government sector. The relevant full information is not yet available. However, as discussed in paragraph 2 of the staff report, preliminary data strongly suggest that the performance criterion was met. 


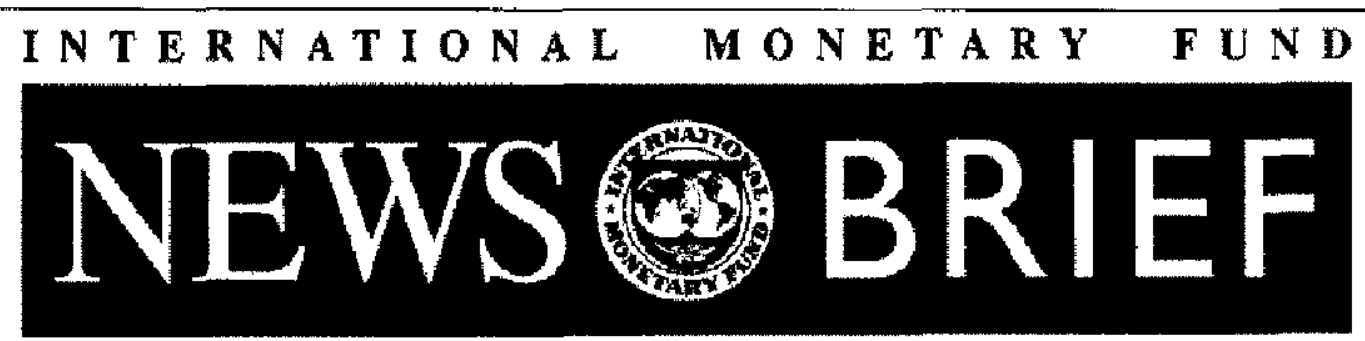

FOR IMMEDIATE RELEASE

News Brief No. 02/57

FOR IMMEDIATE RELEASE

June 28, 2002
International Monetary Fund

700 19th Street, NW

Washington, D. C. 20431 USA

\section{IMF Approves US\$1.15 Billion Tranche to Turkey under Stand-By Credit}

The Executive Board of the International Monetary Fund (IMF) today completed the second review of Turkey's economic performance under the three-year stand-by credit. The decision will enable Turkey to draw up to SDR 867.6 million (about US\$1.15 billion) immediately.

The stand-by credit was approved on February 4, 2002 (see Press Release No. 02/7) in a total amount of SDR 12.8 billion (about US $\$ 17$ billion). So far, Turkey has drawn SDR 8.2 billion (about US $\$ 11$ billion).

After the Executive Board discussion on Turkey, Horst Köhler, Managing Director and Chair, said:

"The Turkish authorities are to be commended for their strong policy performance. Fiscal policy has remained on course; the Central Bank of Turkey (CBT) has adhered to a prudent monetary policy; and structural reforms in banking and in the public sector have been impressive. These policies have delivered a sharp drop in inflation and inflation expectations, and the beginnings of an economic recovery.

"The significant fiscal adjustment of the last two years has been one of the main achievements of the program. The authorities' commitment to maintaining the present strong fiscal stance in 2003 and over the medium term will play a crucial part in ensuring debt sustainability. The recent decisions to bring price increases in state economic enterprises back on track are a strong signal of this commitment. Going forward, this should be reinforced with reforms in direct taxes, a prudently managed reduction of 
redundant staff positions in state economic enterprises, and improved tax administration and procurement procedures.

"The central bank's contribution to reducing inflation and inflation expectations is a further major achievement. This should now be strengthened by advancing with the technical preparations for inflation targeting. The central bank should continue its policy of gradually building up its foreign exchange reserves, as long as the underlying balance of payments position permits. The authorities should also move further to reduce tax distortions in financial markets.

"The Bank Regulation and Supervision Agency (BRSA) has handled skillfully the private bank audit and recapitalization exercise and has demonstrated, through its recent action, its commitment to strengthening Turkey's financial system. Together with adoption of the Istanbul Approach for corporate debt restructuring, and planned improvements in the legal framework for bankruptcy, this will set the stage for a lasting recovery in credit growth.

"Greater attention needs to be devoted to structural reform, especially privatization, in the period ahead. In the light of the inefficiencies in state enterprises and the burden they place on the budget, the authorities should intensify their efforts to privatize these enterprises. The recent presentation to parliament of a new Foreign Direct Investment Law is an important step in improving the business environment and supporting the privatization efforts.

'Overall, the authorities' impressive policy implementation has been producing tangible gains. Vulnerabilities remain, however, as evidenced by recent financial market developments. Full implementation of the program strategy is therefore essential to create sustained economic growth. For these efforts to be fully successful, a critical priority will be to provide reassurance to markets about economic, financial, and political stability, and thus the long-term credibility of Turkey's reform efforts," Mr. Köhler said. 


\section{Turkey-The Authorities' Statement on the Staff Report for the Second Review Under the Stand-By Arrangement}

\section{- Page 28/Box 4/Paragraph 4/paragraph 4 and 7:}

Paragraph 4 analyses the provisioning of banks for NPLs and reaches the conclusion that banks have been cautious in valuing collateral and that eventhough the average of reserves put aside equals to $40 \%$ of NPLs, the range of provisioning for NPLs among banks vary from $30 \%$ of NPL to more than $50 \%$ of NPL. The paragraph further asserts that with the introduction of inflation accounting, some banks were able to increase provisioning without having to raise capital. In support of this argument, it is stated in the paragraph that shareholders equity increased by roughly USD 1.5 billion. It is claimed also that of this amount only $40 \%$ come from an increase in paid-in capital and that the rest come from increased asset valuation due to inflation accounting. Similarly, a reference to the impact of the introduction of inflation accounting is made in the paragraph 7 and it is concluded that this implementation reduced the amount of capital some banks had to raise.

Yet, the capital increase of US\$1.5 billion was realized in 2001, prior to the inflation accounting application which was required only within the recapitalization scheme. Therefore, the analysis and conclusions in these paragraphs lacks accurateness and creates confusion. Indeed, as explained in detail in the "Bank Capital Strengthening Program Progress Report" (which is available at the BRSA's web site www.bddk.org.tr), inflation accounting has not been used as an instrument to reduce banks' capital need in a fictitious way. In contrast, it has been applied to financial statements dated December 31, 2001 in order to determine the banks' need for capital in a correct manner. There has not been a single bank, of which the CAR was initially below $8 \%$ and exceeded this ratio upon the application of inflation accounting. Furthermore, banks included in the program had to announce high amounts of losses due to inflation accounting.

\section{- Page 28/Box 4/Paragraph 5:}

The above-referred paragraph entails a comparison of profitability figures before and after the audits. However, the audits conducted on a three stage basis all in compliance with international standards use different principles and methodologies than those before the audits. Therefore, the comparison of before and after profit figures are not meaningfully comparable.

\section{- Page 28/Box 4/ Paragraph 6/last sentence:}

The above-referred paragraph expresses the capital shortfall of the banks with regard to BRSA's assessment under the result of the audits and it states that capital shortfall in banks amounted to TL 1,326 trillion as of end-2001, which is less than the preliminary figure of USD 1 billion. Following these expressions, it is stated that banks have already raised or 
committed to raise roughly US $\$ 0,8$ billion, with a considerable portion of this coming from retained earnings.

The increase in the capital raised or committed, however, does not stem mainly from the retained earnings. The main measures include a cash capital injection of TL 162 trillion $(\$ 106 \mathrm{mn}$ ) and a non-performing loan collection of TL 738 trillion ( $\$ 482 \mathrm{mn})$, with TL 468 trillion ( $\$ 305 \mathrm{mn}$ ) part of the latter amount constituting the collection of nonperforming loans extended to majority shareholders. The $14 \%$ decrease in exchange rate risk due to banks closing their balance sheet open position during the December 2001-May 2002 period reduced the capital requirements for market risk by TL 72 trillion ( $\$ 47 \mathrm{mn}$ ). Together with the above-mentioned measures, the increase in the value of government papers in the securities portfolio by TL 130 trillion ( $\$ 85 \mathrm{mr}$ ) has been an important development that reduced capital needs. Therefore, the sentence "... with a considerable portion of this coming from retained earnings." does not reflect the actual sources of capital injections made by banks.

\section{Page 37/Table 1/Article 1/Status section:}

This part of the report states that BRSA sent letters to banks with four-week delay. This fourweek delay, however, was due to the extension given to the independent auditors upon their request, with the aim of enabling them to complete the audit work with due care and in full compliance with the pre-determined principles, procedures and methods as set by the related regulation of the BRSA.

\section{Factual corrections in the report are as follows:}

\section{Page 26, Para 19:}

The sentence concerning the cost of financial intermediation makes a reference to a levy of 10 percent of interest income on bank loans. However, this levy of 10 percent [-the Resources Utilization Support Fund (RUSF)] deduction-applies to lending rates on consumer loans not bank loans ( 3 percent for other loans) and the borrowers pay the deductions.

\section{Table 12. Turkey: Public Sector Financing Indicators, 2001-02 (p.60)*}

The domestic debt figures pertaining to the total and private roll over ratios for January-June 2002 need to be corrected. The corrected data given in the attached table for the "Net domestic borrowing/redemptions" item reflects the realization figures for the January-July 2002 period and is derived from monthly realizations for domestic debt service and borrowing amounts. 


\begin{tabular}{|lcc|}
\hline $\begin{array}{l}\text { *These figures should be revised as follows: } \\
\text { Ratio of new domestic } \\
\text { borrowing to redemptions }\end{array}$ & Total & Private Sector \\
2001 & $76 \%$ & $97 \%$ \\
2002 & & \\
January & $99 \%$ & $114 \%$ \\
February & $61 \% *$ & $101 \%$ \\
March & $96 \%$ & $117 \%$ \\
April & $104 \%$ & $131 \%$ \\
May & $56 \%$ & $88 \%$ \\
June & $93 \%$ & $99 \%$ \\
July & $99 \%$ & $104 \%$ \\
* In February, ratio of new domestic borrowing to redemptions does not include early \\
redemptions made of IMF credit.
\end{tabular}

